Prepared for the U.S. Department of Energy under Contract DE-AC05-76RL01830

\title{
Canada Geese at the Hanford Site - Trends in Reproductive Success, Migration Patterns, and Contaminant Concentrations
}
MA Simmons
A Stegen
TM Poston
KD Hand
BL Tiller
JM Brandenberger

May 2010

Pacific Northwest

NATIONAL LABORATORY

Proudly Operated by Battelle Since 1965 


\title{
DISCLAIMER
}

This report was prepared as an account of work sponsored by an agency of the United States Government. Neither the United States Government nor any agency thereof, nor Battelle Memorial Institute, nor any of their employees, makes any warranty, express or implied, or assumes any legal liability or responsibility for the accuracy, completeness, or usefulness of any information, apparatus, product, or process disclosed, or represents that its use would not infringe privately owned rights. Reference herein to any specific commercial product, process, or service by trade name, trademark, manufacturer, or otherwise does not necessarily constitute or imply its endorsement, recommendation, or favoring by the United States Government or any agency thereof, or Battelle Memorial Institute. The views and opinions of authors expressed herein do not necessarily state or reflect those of the United States Government or any agency thereof.

\author{
PACIFIC NORTHWEST NATIONAL LABORATORY \\ operated by \\ BATTELLE \\ for the \\ UNITED STATES DEPARTMENT OF ENERGY \\ under Contract DE-AC05-76RL01830
}

Printed in the United States of America
Available to DOE and DOE contractors from the
Office of Scientific and Technical Information,
P.O. Box 62, Oak Ridge, TN 37831-0062;
ph: (865) 576-8401
fax: $(865) 576-5728$
email: reports@adonis.osti.gov

\author{
Available to the public from the National Technical Information Service, \\ U.S. Department of Commerce, 5285 Port Royal Rd., Springfield, VA 22161 \\ ph: (800) 553-6847 \\ fax: $(703) 605-6900$ \\ email: orders@ntis.fedworld.gov \\ online ordering: http://www.ntis.gov/ordering.htm
}

This document was printed on recycled paper. 


\title{
Canada Geese at the Hanford Site - Trends in Reproductive Success, Migration Patterns, and Contaminant Concentrations
}

\author{
MA Simmons \\ A Stegen \\ TM Poston \\ KD Hand \\ BL Tiller ${ }^{1}$ \\ JM Brandenberger
}

May 2010

Prepared for

the U.S. Department of Energy

under Contract DE-AC05-76RL01830

Pacific Northwest National Laboratory

Richland, Washington 99352

${ }^{1}$ Environmental Assessment Services, Richland, Washington 


\section{Summary}

Pacific Northwest National Laboratory (PNNL) has conducted several studies for the U.S. Department of Energy (DOE) to evaluate the status and condition of Canada geese on the Hanford Reach of the Columbia River. This report summarizes results of studies of Canada geese (Branta canadensis moffitti) at the Hanford Site dating back to the 1950s. Results include information on the nesting (reproductive) success of Canada geese using the Hanford Reach, review of the local and regional migration of this species using data from bird banding studies, and summary data describing monitoring and investigations of the accumulation of Hanford-derived and environmental contaminants by resident goose populations.

Canada goose nesting success has been studied on 20 islands within the Hanford Reach since 1953. The Hanford Reach generally is considered a free-flowing stretch of the Columbia between the tailrace of Priest Rapids Dam and the edge of McNary pool just north of Richland. Islands within the Hanford Reach north of Richland fall naturally into two groups based on their geographic location - the upper 10 islands border the Hanford Site near the retired reactor areas (100-D Area to an area $2 \mathrm{~km}$ downstream of the 100 F Area); the lower 10 islands border the eastern edge of the Hanford Site near Ringold downstream to the city of Richland. The number of Canada goose nests found on the islands has varied from more than 300 in 1958 and 1991 to around 110 in 1975 and 1976. Before 1970, nesting occurred primarily on the upper islands in the Hanford Reach. After 1970, nesting shifted from the upper to the lower islands, with up to $90 \%$ of the Canada goose nests found on the lower islands in recent years. The shift from upper to lower islands appears to have been precipitated primarily by an increase in predation, particularly by coyotes on the largest island, Locke Island (Island 6).

Differences between the upper and lower islands were reflected also in the nesting success and clutch size. Nesting success was $66.7 \%$ on the upper islands compared to $74.3 \%$ on the lower islands, while average clutch size was 5.0 on the upper islands compared to 5.9 on the lower islands. There appears to be no difference in hatching rates between the island groups. The nesting success differences between upper and lower islands may be a result of the higher predation on the upper islands. Predation could have a two-fold impact - first, it would reduce the number of successful nests; second, the clutch size of any additional nesting attempts would be smaller.

Adult and juvenile geese were banded after juvenile fledging to determine the extent of migration by the goose population at the Hanford Site. Banding returns indicate that some birds migrated southward to California and/or northeast into southern Canada. However, on average, $60 \%$ of the band returns were local (i.e., within $80 \mathrm{~km}$ ). The percentage of local returns has changed since the 1950 s from approximately $59 \%$ to $73 \%$ in the 1980 s.

Contaminant concentrations found in goose tissue were evaluated based on data available in the Hanford Environmental Information System (HEIS) database. The HEIS contains data for the period extending from 1971 through 2007. ${ }^{1}$ Contaminant data were collected primarily under the Surface Environmental Surveillance Project conducted by PNNL on the Hanford Site for DOE. The contaminant results evaluated in this report represent the period following the shutdown of single-pass plutonium production reactors. Summaries of the available data indicate that the accumulation of activation

\footnotetext{
${ }^{1}$ Data from years prior to 1971 are not in electronic format and concentrate on short-lived radionuclides associated with operation of the Hanford Site single-pass reactors.
} 
products in Canada geese was low and associated dose rates were well below applicable guidelines. Strontium-90 and cesium-137 were the predominant radionuclides observed in Canada goose samples following the shutdown of the reactors. Strontium-90 still is observed in recently collected goose bone and eggshell samples, although concentrations are now the same as those for reference locations.

Statistical analysis of metal concentrations found in goose tissues revealed that arsenic, chromium, copper, lead, mercury, selenium, and thallium concentrations are slightly elevated in liver tissue from the Hanford Site when compared to samples collected at the offsite reference locations. However, the maximum concentrations of these metals met or fell below existing toxicological benchmarks, suggesting minimal risk to Canada geese from exposure to these metals. 


\section{Acknowledgments}

The nesting and bird banding data analyzed in this report were collected under the direction of W. C. Hanson, R. E. Fitzner, L. E. Eberhardt, R. Mazaika, and B. L. Tiller. A large part of the contaminant data was collected as part of the Surface Environmental Surveillance Project under the supervision of M. R. Quarders, E. W. Lusty, S. F. Conley, and R. W. Hanf, Jr. K. R. Price, and W. H. Rickard have provided guidance in sampling wildlife and contaminant analyses at Hanford over the last 30 years. Radiological analyses were performed by Severn Trent Laboratory or companies that managed the operation and facilities during the period of study. Metals analyses were performed by the Pacific Northwest National Laboratory in Sequim, Washington. We also thank the U.S. Department of Energy and its predecessor agencies (the U.S. Atomic Energy Commission and the Energy Research and Development Administration) for their continued support. We thank C. J. Driver, L. L. Cadwell, J. L. Downs, and R. L. Dirkes for thought-provoking and stimulating comments on earlier drafts of this report. Editor A. J. Currie and publications designers K. R. Neiderhiser, L. M. Andor, and M. R. Spanner finalized this report for publication. 


\section{Acronyms and Abbreviations}

\begin{tabular}{|c|c|}
\hline ANOVA & analysis of variance \\
\hline CVAA & cold vapor atomic absorption \\
\hline DCF & dose conversion factor \\
\hline $\begin{array}{l}\text { DOE } \\
\text { dry wt }\end{array}$ & $\begin{array}{l}\text { U.S. Department of Energy } \\
\text { dry weight }\end{array}$ \\
\hline EPA & U.S. Environmental Protection Agency \\
\hline ERED & Environmental Residue-Effects Database \\
\hline HEIS & Hanford Environmental Information System \\
\hline $\mathrm{ICP}$ & inductively coupled plasma (spectrometry) \\
\hline ICP-MS & inductively coupled plasma mass spectrometry \\
\hline ICP-OES & inductively coupled plasma optical emission spectrometry \\
\hline LADL & laboratory achieved detection limit \\
\hline MDC & minimum detectable concentration \\
\hline$N$ & number of samples \\
\hline NA & not applicable or not available \\
\hline$P$ & probability of wrongly rejecting the null hypothesis \\
\hline $\mathrm{pCi} / \mathrm{g}$ & picocurie(s) per gram \\
\hline PNNL & Pacific Northwest National Laboratory \\
\hline RK & river kilometer \\
\hline $\mathrm{RM}$ & river mile \\
\hline $\mathrm{SD}$ & standard deviation \\
\hline st. error or SE & standard error (of the mean) \\
\hline USACE & U.S. Army Corps of Engineers \\
\hline USGS & U.S. Geological Survey \\
\hline wet wt & wet weight \\
\hline $\mathrm{XRF}$ & $\mathrm{x}$-ray fluorescence \\
\hline$\mu \mathrm{g} / \mathrm{g}$ & microgram(s) per gram \\
\hline
\end{tabular}




\section{Contents}

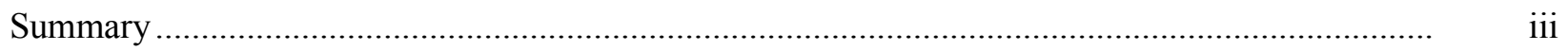

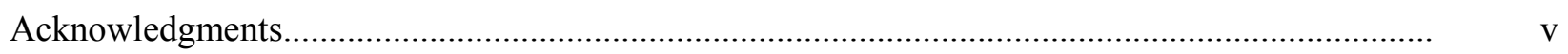

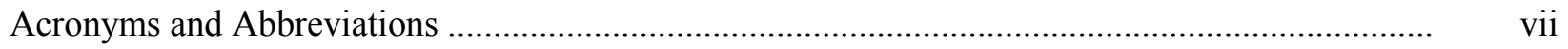

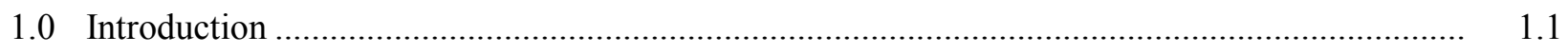

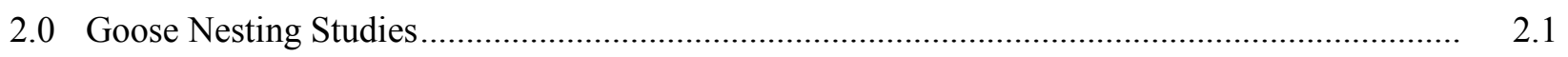

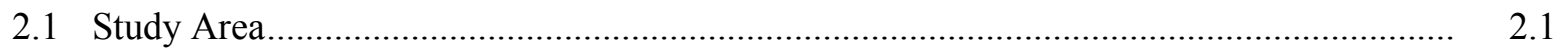

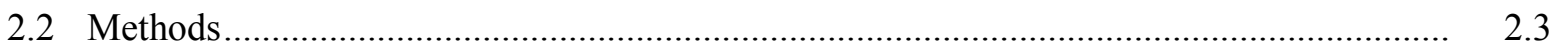

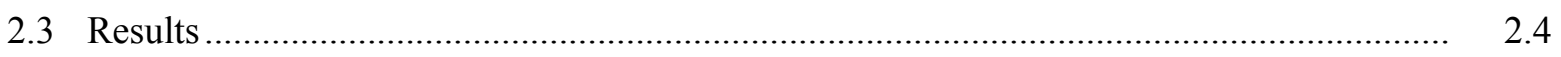

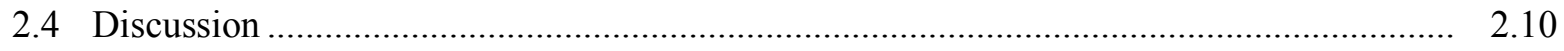

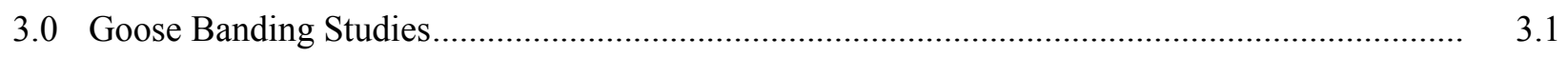

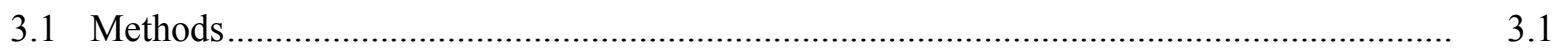

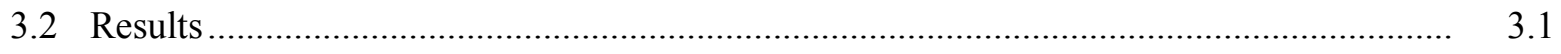

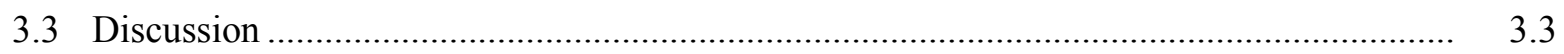

4.0 Surveillance of Contaminants in Canada Geese ...................................................................

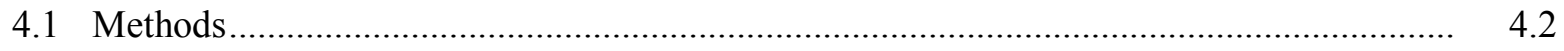

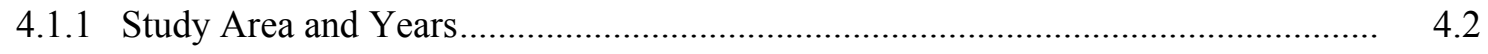

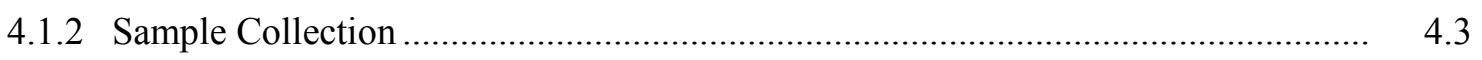

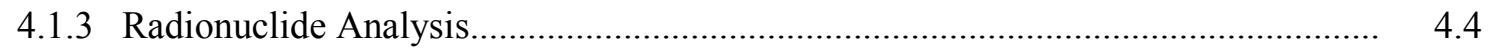

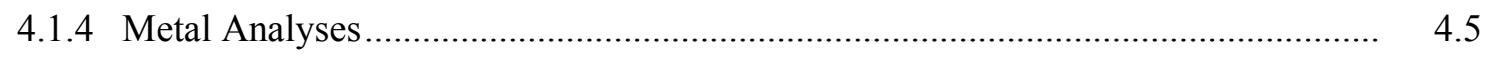

4.1.5 Grouping of Metals by Detection Limits ......................................................... 4.6

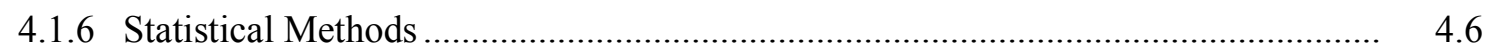

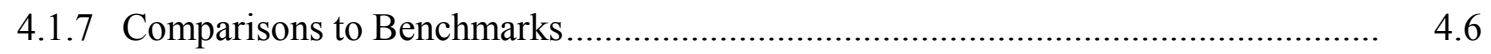

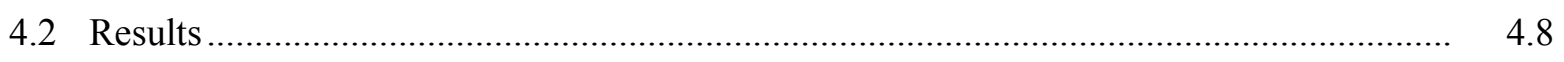

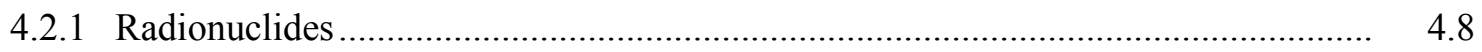

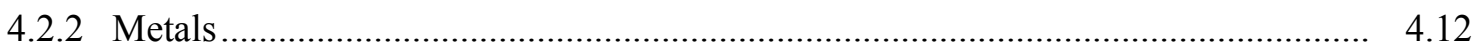

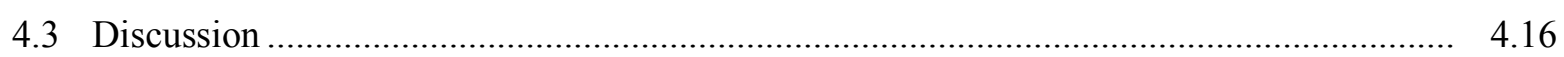

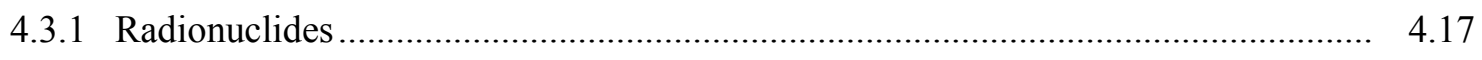

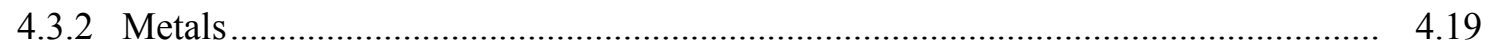

4.3.3 Metals in Canada Goose Eggshells .................................................................. 4.22

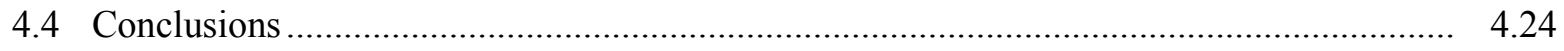

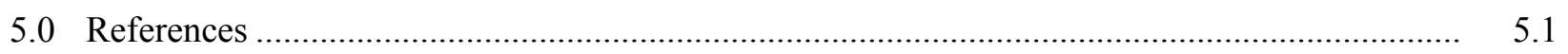

Appendix A - Supplemental Data Tables on Metal Contaminants in Canada Geese...................... A.1

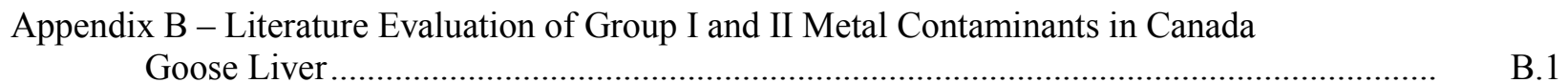




\section{Figures}

2.1 Islands in the Hanford Reach of the Columbia River Used by Canada Geese for Nesting, 1957-2001

2.2 Number of Canada Goose Nests over Time on Upper Islands Compared to Lower Islands in the Hanford Reach, Columbia River

2.3 Mean Nesting Density for Canada Geese on Islands in the Hanford Reach, Columbia River, for 1957-1970 and 1971-2001.

2.4 Number of Canada Goose Eggs per Nest for Upper Islands and Lower Islands in the Hanford Reach, Columbia River

2.5 Clutch Size for Canada Goose Nests on Islands in the Hanford Reach as a Function of Date First Observed.

2.6 Hatching Rate for Successful Nests on Upper Islands and Lower Islands on the Hanford Reach, Columbia River.

2.7 Daily Average Stream Flow in Cubic Feet per Second Monitored on the Columbia River Downstream from Priest Rapids Dam

3.1 Recovery Rates for Adult and Juvenile Canada Geese Banded Either 1950-1970 or 1983-1994

3.2 Recovery Rate for Canada Geese by Banding Year and Age at Banding

3.3 Number of Canada Geese Recovered as a Function of Years Since Banding and Age at Banding

3.4 Distribution of Recoveries of Canada Geese Banded in Hanford Reach Vicinity, 1950-1994

4.1 Canada Goose Collection Locations in the Hanford Reach of the Columbia River and at the Upstream Reference Location, 1971-2007

4.2 Cobalt-60 in Canada Goose Muscle, 1971-2007...

4.3 Cesium-137 in Canada Goose Muscle, 1971-2007

4.4 Strontium-90 in Canada Goose Bone, 1994-2007

4.5 Maximum, Median, and Minimum Concentrations of Strontium-90 in Canada Goose Bone by Sampling Area, 1994-2007

4.6 Mean Strontium-90 Concentration in Canada Goose Eggshells from Islands in the Hanford Reach, Columbia River, 1985-2001

4.7 Mean of Group I Metal Concentrations in Canada Goose Liver ...

4.8 Comparison of the Concentrations of Hepatic Metals in Geese from the Hanford Site and Associated Reference Areas with Values Obtained in a Review of Technical Literature of Other Waterfowl 


\section{Tables}

2.1 Area of Islands in the Hanford Reach of the Columbia River ................................................. 2.2

2.2 Fate of Canada Goose Nests on Islands in the Hanford Reach, Columbia River, 1957-2001 ..... 2.5

2.3 Percentage of Canada Goose Nests Classified as Successful, Predated, Abandoned, Flooded, or Fate Unknown for Upper and Lower Islands in the Hanford Reach, Columbia River

2.4 Number of Canada Goose Nests on All Islands and on Island 6 in the Hanford Reach of the Columbia River for the Survey Period.

2.5 Clutch Size and Hatching Proportion as a Function of Number of Surveys to a Nest Once Eggs Were Present

3.1 Number of Canada Geese Recoveries by Age at Banding, Banding Years, and Recovery Distance

4.1 Laboratory-Achieved Detection Limits for Group I and II Metals

4.2 Median and Maximum Radionuclide Concentrations Reported in Canada Goose Muscle Samples After Cessation of Single-Pass Reactor Operations in 1971

4.3 ANOVA Based on Onsite Versus Offsite and Specific Sample Location of Hepatic Metal Concentrations in Canada Geese, 2003-2007.

4.4 Metal Concentrations in Eggshells from Nests with Either 100\% Hatch or Less Than $100 \%$ Hatch in 2006

4.5 Conservative Radiological Dose Rates Associated with Maximum Radionuclide Concentrations in Canada Goose Tissue Samples Collected from 1971-2005

4.6 Mean Heavy Metal Concentrations in Eggshells from Canada Geese Compared to Those of Other Birds Collected from Reference or Polluted Sites, 2001 Data 


\subsection{Introduction}

Canada geese (Branta canadensis moffitti) found along the Hanford Reach of the Columbia River in southeastern Washington have been studied since the early 1950s as part of contaminant and wildlife monitoring to assess the potential effects of Hanford Site operations on wildlife. The health and status of Canada goose populations and of waterfowl in general are of interest to the public and provide a metric against which to assess the potential influence of historic Hanford Site operations on wildlife using the Hanford Reach. Pacific Northwest National Laboratory (PNNL) and its predecessor, General Electric, have conducted wildlife monitoring and contaminant surveillance studies of this species for the U.S. Department of Energy (DOE) as well as its predecessor agencies (the U.S. Atomic Energy Commission and the U.S. Energy Research and Development Administration) to evaluate the condition of the population, detect population trends, and assess contaminant burdens found in geese. This report documents those studies and provides a synthesis of information regarding the condition and status of Canada geese that inhabit the Hanford Reach.

The Canada geese in the Hanford Reach are a mixture of resident and migrant birds (Hanson and Eberhardt 1971; Ball et al. 1981). Migrant birds arrive in early spring, with nesting by both resident and migrants occurring in April and May. After hatching, the young leave the nest to forage in nearby areas (Eberhardt et al. 1989b) and fledge approximately 10 weeks after hatching (Eberhardt et al. 1989b). Some birds appear to leave the area throughout the summer and early fall, while others remain resident (Hanson and Eberhardt 1971; Eberhardt et al. 1989b). Fall migrants also visit the region and may include lesser Canada geese (B. c. parvipes). Canada geese are primarily herbivores preferring grasses and sedges, including grains; they also eat insects, crustaceans, and mollusks.

The primary metric used to assess the health of Canada geese is nesting performance (Hanson and Browning 1959; Hanson and Eberhardt 1971; DeWaard 1981; Fitzner and Rickard 1983; Fitzner et al. 1994). Long-term monitoring of nesting performance also provides a way to evaluate the potential effects of legacy contamination from reactor operations, changes introduced by upstream hydroelectric dams, and increased recreational use of the Columbia River.

Two other types of studies of Canada geese on the Hanford Reach are included in this report. Banding studies provide information on the migration patterns of Hanford Site geese and show changes in local residency (Hanson and Eberhardt 1971), and aid in quantifying the movement, activity budgets, and survival of broods (Eberhardt et al. 1989a, b, c). Ongoing contaminant surveillance and monitoring studies have documented the levels of site-related contaminants found in geese at the site (Rickard and Sweany 1977; Rickard and Price 1990; Rickard and Schuler 1990; Dirkes and Hanf 1996, 1998; Poston et al. 2000, 2002, 2004, 2006, 2008).

The results of these investigations are reported in three sections. Section 2 provides the summary of data and information describing nearly 50 years of monitoring nesting success and extends the analyses reported by Hanson and Eberhardt (1971), Fitzner and Rickard (1983), and Fitzner et al. (1994). Section 3 documents migration patterns for Canada geese banded from 1950 through 1994. Section 4 presents a summary of the contaminants found in Canada geese at the Hanford Site and a description of the trends in contaminant tissue burdens from 1971 through 2007. 


\subsection{Goose Nesting Studies}

The presence of large numbers of Canada geese nesting in the Hanford Reach is a relatively recent phenomenon. Before the 1940s, goose nests were subjected to human and animal predation and flooding. With the establishment of the Hanford Reservation in 1943, access to the area and, in particular, the islands in the Hanford Reach, was restricted. In addition, changes in regional farming practices reduced the rural population while increasing the potential food sources for the geese. Construction of upstream hydroelectric dams reduced water-level fluctuations, opening up more island area for nesting. All these changes favored the Canada goose nesting population within the Hanford Reach (Hanson and Eberhardt 1971).

Changes continue today along the Hanford Reach. The Hanford Reach of the Columbia, along with other Hanford Site lands, was designated a National Monument in 2000 (65 FR 37253). In addition, all DOE nuclear reactors on the Hanford Site have been decommissioned, and the site is in the midst of cleanup activities. These changes have increased the usage of the area for recreational activities that can potentially disturb nesting activities.

Since the early 1950s, researchers have studied the nesting success of Canada geese found on the Hanford Reach (Hanson and Browning 1959; Hanson and Eberhardt 1971; DeWaard 1981; Fitzner and Rickard 1983; Fitzner et al. 1994). Nesting surveys were initiated in 1953 to document the reproductive performance of the goose population and determine whether nesting success was affected by nuclear reactor operations on the Hanford Site.

This section describes the results of surveys from 1957 through 2001 and documents the history and long-term trends in the status of the Canada goose nesting population with respect to the number of nests, nesting success, hatching rates, and clutch sizes.

\subsection{Study Area}

The Hanford Reach is the 88-km segment of the Columbia River considered the only free-flowing segment of the river in the United States upstream of Bonneville Dam. The Hanford Reach lies between McNary and Priest Rapids dams in southeastern Washington at the southern edge of the Columbia Plateau. Canada geese nest almost exclusively within a group of islands that extend from river kilometer (RK) 547 to 607 (river mile [RM] 340 to 377) (Figure 2.1). Some nesting also occurs along the river shoreline, especially on the White Bluffs.

The islands fall naturally into two groups: upper (Islands 1 through 10 in the upriver section of the Hanford Reach) and lower (Islands 11 through 20 in the downriver portion of the Hanford Reach) (Figure 2.1). The island south of Island 20 was not included for a variety of reasons, including its proximity to shore (at low water, there is a land bridge) and to population centers. The sizes of the islands vary from 2 to 3 ha (Islands 4, 5, and 10) to more than 120 ha (Island 6 or Locke Island) (DeWaard 1981; Table 2.1). These sizes were determined in 1979 from aerial photographs and were approximately $30 \%$ larger than those reported in Hanson and Eberhardt (1971) due to differences in water elevation at the time the photographs were taken. Erosion also affects island size, and Locke Island (Island 6) has experienced significant erosion since the 1990s (Bjornstad 2006). Elevational profile of the island is 
another factor affecting nesting; nesting has occurred on Island 16 only three times in over 40 years because it has a lower profile and is subject to frequent flooding in the spring (Hanson and Eberhardt 1971).

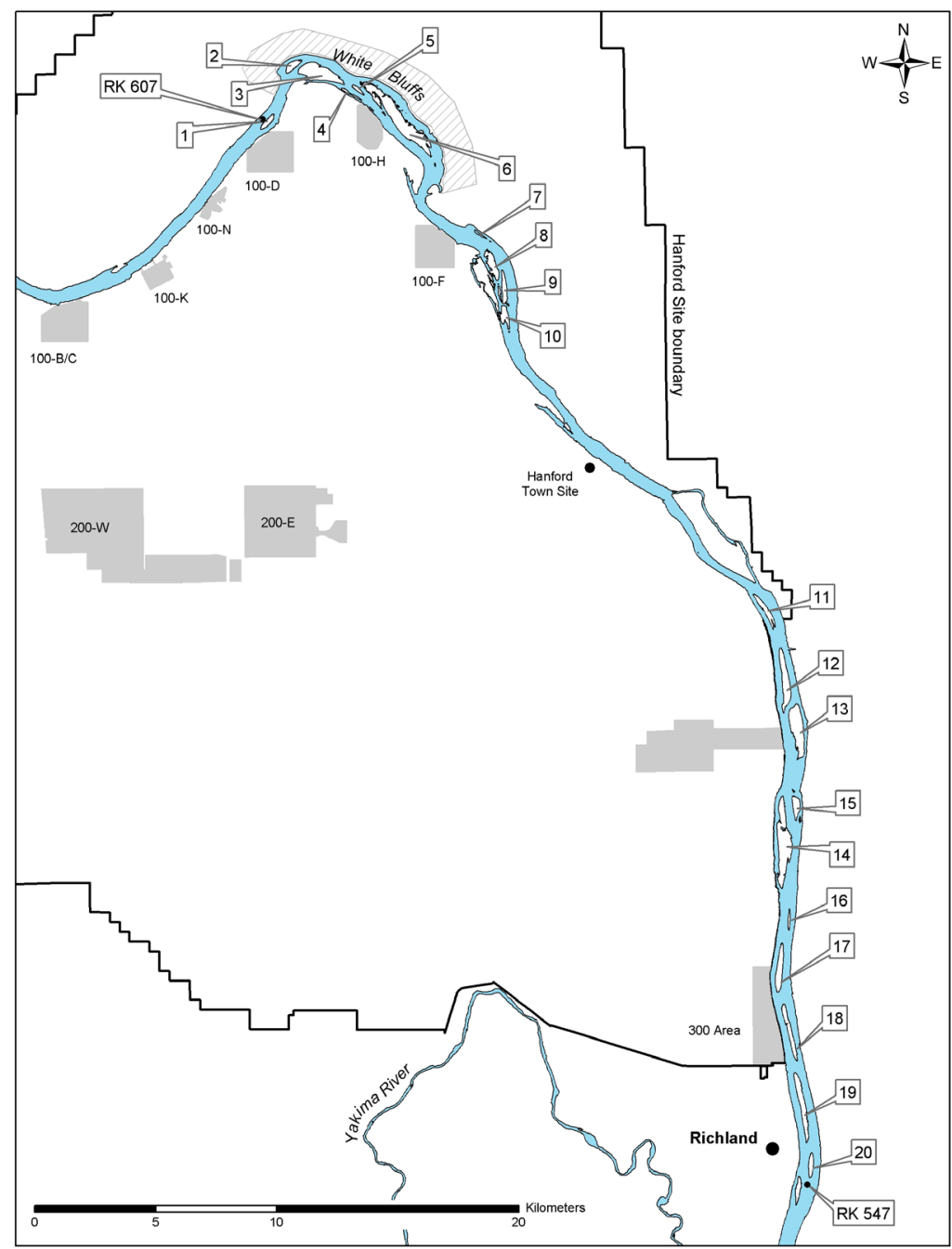

Figure 2.1. Islands in the Hanford Reach of the Columbia River Used by Canada Geese for Nesting, 1957-2001

Table 2.1. Area of Islands in the Hanford Reach of the Columbia River (DeWaard 1981)

\begin{tabular}{lcccccccccc}
\hline & \multicolumn{10}{c}{ Upper Islands } \\
\cline { 2 - 11 } Island No. & 1 & 2 & 3 & 4 & 5 & 6 & 7 & 8 & 9 & 10 \\
Area (ha) & 7.3 & 8.3 & 62.3 & 2.5 & 2.8 & 121.1 & 6.8 & 17.3 & 13.8 & 1.7 \\
\hline & \multicolumn{10}{c}{ Lower Islands } \\
\cline { 2 - 11 } Island No. & 11 & 12 & 13 & 14 & 15 & 16 & 17 & 18 & 19 & 20 \\
Area (ha) & 20.7 & 46.0 & 66.3 & 93.8 & 14.4 & -- & 37.6 & 28.8 & 47.7 & 12.8 \\
\hline
\end{tabular}


Several of the upper islands are adjacent to or immediately downstream of reactors used for plutonium production during the Cold War. Various reactors were in operation between 1944 and 1987. Additionally, between 1943 and 1977, boating access to Islands 1 to 11 was restricted due to their proximity to the reactors (DeWaard 1981). Two islands in the lower group of islands are adjacent to the city of Richland (Islands 19 and 20), while Islands 17 and 18 are adjacent to the 300 Area that was used for reactor fuel fabrication, research and development, and solid and liquid waste disposal. Island 13 is opposite the outfall from the Northwest Energy Columbia Generating Station, Washington State's only currently operating commercial nuclear power plant; the plant went online in 1984.

Vegetation on the islands consists of two main forms - shoreline riparian vegetation and upland vegetation away from the water. Along the shoreline, a number of different riparian vegetation cover types dominate depending on substrate, island topography, and aspect. The most common riparian habitat types are low shrub-forb-cobble (about $22 \%$ of the mapped vegetation on islands) and riparian grasses (about $4 \%$ including reed canarygrass, Phalaris arundinaceae). Species that commonly occur in low shrub-forb-cobble vegetation include mulberry (Morus alba) and low rhizomatous subshrubs such as common dogbane (Apocynum caninum), western goldenrod (Solidago occidentalis), and scattered herbs. Since the surveys began in the 1950s, the primary vegetative change has been the establishment of tree and shrub willows (Salix spp.) on many of the islands. Upland vegetation cover types include both shrub-steppe species (13\% of mapped area) and an upland transition zone ( $25 \%$ of the mapped area of the islands) dominated by riparian Artemisia subshrub species (e.g., Artemisia campestris or northern wormwood) and perennial grasses (e.g., Sporobolus cryptandrus) or forbs. Exotic weeds such as knapweeds and cheatgrass dominate portions of the riparian and upland elevations on many of the islands, particularly Locke Island (Island 6).

\subsection{Methods}

Nesting success of the geese was determined by counting nests and documenting the fate of the eggs within a nest. Surveys were conducted annually between 1953 and 1995 and biannually thereafter until 2001, when the surveys ceased. Surveys usually began the last week of March unless mild temperatures and early pairing of geese were noted. Nests generally were revisited every 10 to 14 days until hatching ended in May. Abbreviated surveys were conducted in 1959 when only a single visit was made to evaluate the effect of human disturbance on nesting success, and in 1997, when nests were visited twice, at the beginning and toward the end of the normal hatching period. Data for these years were not included in the analysis of nesting trends. In addition, archived data sets were incomplete before 1957; analyses are therefore based on data for 1957 through 2001.

Nests were located during walking surveys of each island. Each located nest was numbered and flagged, and the number of eggs was recorded, as was a description of the substrate and dominant vegetation. Nest surveys were repeated at approximately 2 -week intervals to determine the fate of the eggs in each nest. When nests were examined, a determination was made for each egg as to whether it had hatched, was destroyed by a predator (i.e., predated) ${ }^{1}$, had been abandoned, had been subjected to flooding, or, if the egg could not be accounted for, the fate was classed as unknown. Unhatched eggs remaining in the nest at the end of the nesting season were opened to determine whether they were fertile

\footnotetext{
${ }^{1}$ See https://listserv.umd.edu/cgi-bin/wa?A2=ind0411c\&L=ecolog-1\&O=D\&P=186 for a discussion on the use of predate vs. depredate.
} 
or infertile. Those eggs with yolk wholly or partially suspended in the albumen were classified as infertile, while eggs containing embryos were classified as fertile.

Nesting success was characterized according to the following criteria. A successful nest had at least one egg hatch. If no eggs hatched, the fate of the nest was classified based on the presence of predated eggs, abandoned eggs, and flooded eggs, in that order. If none of these conditions was documented for a nest, then the fate of the nest was classified as unknown. Although a nest might contain eggs with different fates, the nest itself was assigned to only a single classification.

The measure of nesting success is generally based on the ratio of successful nests to total nests and is termed the apparent nest success. This measure is biased if unsuccessful nests are undercounted. Undercounting can occur if the nests are hard to locate, if there are multiple nesting attempts, or if there are multiple clutches. To reduce the bias, estimators such as the Mayfield estimator are often used (Johnson and Shaffer 1990). However, nesting on islands presents a unique situation, especially in the arid environment of the Hanford Reach where visibility is very high. In nearly all years, nests were visited while eggs were still being laid, so unsuccessful nesting attempts were more likely to be recorded. In addition, island nesting is considered synchronous, and Canada geese generally have only one clutch a year, so it was considered unlikely that nesting attempts were missed. Our survey techniques might have missed an abandoned nest that was subsequently taken over by another nesting pair. In addition, because adults were not marked, we were not able to distinguish re-nesting attempts. A constraint of the Mayfield estimator is that it assumes a constant mortality rate and performs poorly if mortality is catastrophic. Nesting mortality on islands is generally catastrophic, resulting from flooding events or the introduction of a predator. Thus, for the Hanford Reach islands, no adjustment was made to the estimate of nesting success for Canada geese.

The hatching rate was calculated as the number of hatched eggs per total number of eggs laid and was determined only for nests where at least one egg hatched. Clutch size was the average number of eggs per nest per island.

\subsection{Results}

The number of Canada goose nests on islands of the Hanford Reach has varied from more than 300 in 1958 and 1991 to around 110 in 1975 and 1976 (Table 2.2). Before 1970, an average of $70 \%$ of the nesting occurred on the upper islands in the Hanford Reach. After 1970, there was a shift from the upper to the lower islands (Figure 2.2); 70\% of the Canada goose nests now occur on the lower islands.

Although the total number of nests has changed dramatically between the upper and lower islands, only nine of the islands showed a significant change in density before and after 1970 (Figure 2.3). For the upper islands, three of the four significant changes in nesting density $(P<0.05)$ went from higher nest density before 1970 to lower after 1970. The reverse was true on the lower islands, where all five significant differences indicated higher nesting densities after 1970. For all the islands, Islands 1 and 2 had the highest nesting densities, with around 3.2 nests/ha on Island 1 and 2.1 nests/ha on Island 2. For the remaining islands, density varied from 0.1 nest/ha on Island 7 to 0.7 nest/ha on Island 20. Much of the change in number of nests on the upper islands is attributable to changes occurring on Islands 3 and 6. The highest nesting density on both islands occurred before 1960 and then declined until both were close to zero in 1970. Because Island 6 (Locke Island) is the largest island (more than 120 ha, Table 2.1), the change in density from 0.7 before 1970 to 0.01 after 1970 meant a change in number of nests from more than 80 per year to 1 per year. 
Table 2.2. Fate of Canada Goose Nests on Islands in the Hanford Reach, Columbia River, 1957-2001

\begin{tabular}{|c|c|c|c|c|c|c|c|}
\hline \multirow[b]{2}{*}{ Year } & \multirow[b]{2}{*}{ Total $^{(a)}$} & \multicolumn{5}{|c|}{ Number of Nests } & \multirow{2}{*}{$\begin{array}{c}\text { Average } \\
\text { Clutch Size }\end{array}$} \\
\hline & & Successful & Abandoned & Predated & Flooded & Unknown Fate & \\
\hline 1957 & 265 & 166 & 22 & 47 & 2 & 26 & 4.8 \\
\hline 1958 & 307 & 146 & 57 & 60 & 0 & 43 & 4.7 \\
\hline 1959 & $195^{(\mathrm{b})}$ & & & & & & \\
\hline 1960 & 246 & 165 & 20 & 22 & 4 & 34 & 5.2 \\
\hline 1961 & 231 & 198 & 12 & 11 & 2 & 6 & 5.7 \\
\hline 1962 & 170 & 128 & 6 & 15 & 2 & 18 & 5.3 \\
\hline 1963 & 226 & 146 & 16 & 5 & 0 & 59 & 5.6 \\
\hline 1964 & 166 & 132 & 8 & 8 & 0 & 16 & 5.0 \\
\hline 1965 & 130 & 51 & 31 & 11 & 1 & 30 & 3.9 \\
\hline 1966 & 242 & 180 & 42 & 13 & 0 & 7 & 5.5 \\
\hline 1967 & 187 & 109 & 29 & 42 & 0 & 6 & 5.4 \\
\hline 1968 & 170 & 117 & 25 & 23 & 4 & 1 & 5.6 \\
\hline 1969 & 167 & 133 & 8 & 18 & 4 & 4 & 5.4 \\
\hline 1970 & 119 & 83 & 9 & 18 & 0 & 8 & 5.3 \\
\hline 1971 & 113 & 86 & 4 & 0 & 5 & 16 & 5.3 \\
\hline 1972 & 157 & 127 & 5 & 19 & 0 & 6 & 5.6 \\
\hline 1973 & 130 & 106 & 8 & 8 & 0 & 7 & 5.4 \\
\hline 1974 & 147 & 75 & 14 & 36 & 4 & 18 & 5.0 \\
\hline 1975 & 114 & 83 & 11 & 7 & 0 & 13 & 5.1 \\
\hline 1976 & 112 & 83 & 9 & 8 & 0 & 12 & 5.3 \\
\hline 1977 & 126 & 71 & 5 & 31 & 0 & 19 & 5.1 \\
\hline 1978 & 138 & 105 & 6 & 17 & 0 & 10 & 5.4 \\
\hline 1979 & 133 & 99 & 10 & 9 & 0 & 14 & 5.5 \\
\hline 1980 & 155 & 100 & 26 & 13 & 1 & 15 & 5.3 \\
\hline 1981 & 157 & 124 & 14 & 13 & 0 & 5 & 5.9 \\
\hline 1982 & 172 & 138 & 17 & 11 & 1 & 5 & 5.9 \\
\hline 1983 & 227 & 145 & 13 & 31 & 1 & 35 & 5.7 \\
\hline 1984 & 202 & 124 & 15 & 13 & 1 & 48 & 5.6 \\
\hline 1985 & 193 & 157 & 10 & 19 & 0 & 4 & 5.5 \\
\hline 1986 & 168 & 152 & 7 & 1 & 2 & 6 & 5.9 \\
\hline 1987 & 248 & 179 & 27 & 19 & 11 & 12 & 5.8 \\
\hline 1988 & 215 & 147 & 19 & 26 & 1 & 19 & 5.9 \\
\hline 1989 & 264 & 194 & 6 & 20 & 10 & 34 & 5.3 \\
\hline 1990 & 253 & 194 & 7 & 12 & 16 & 24 & 5.4 \\
\hline 1991 & 316 & 244 & 15 & 15 & 15 & 25 & 5.7 \\
\hline 1992 & 287 & 213 & 10 & 34 & 7 & 23 & 6.1 \\
\hline 1993 & 235 & 196 & 1 & 14 & 0 & 24 & 5.7 \\
\hline 1994 & 181 & 153 & 1 & 5 & 13 & 9 & 5.6 \\
\hline 1995 & 246 & 151 & 8 & 38 & 18 & 31 & 5.7 \\
\hline 1997 & $209^{(b)}$ & & & & & & \\
\hline 1999 & 243 & 198 & 8 & 19 & 4 & 14 & 5.4 \\
\hline 2001 & 228 & 186 & 19 & 15 & 0 & 8 & 5.7 \\
\hline
\end{tabular}

(a) Numbers may not agree with those previously published because of differences in reporting and analysis. Numbers presented are consistent with those in the Ecosystems Monitoring Database.

(b) Limited number of surveys in these years. 


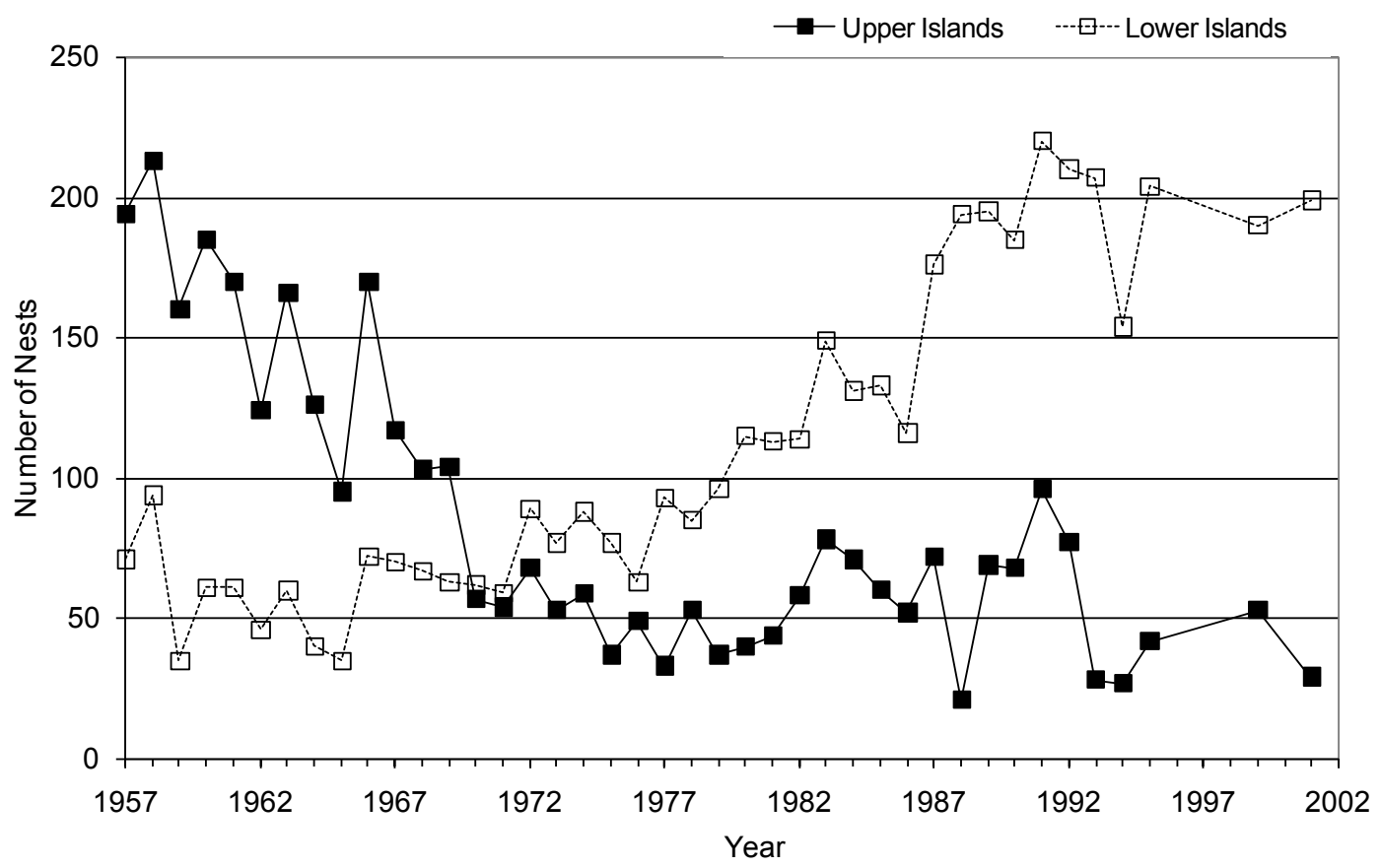

Figure 2.2. Number of Canada Goose Nests over Time on Upper Islands (1 through 10) Compared to Lower Islands (11 through 20) in the Hanford Reach, Columbia River

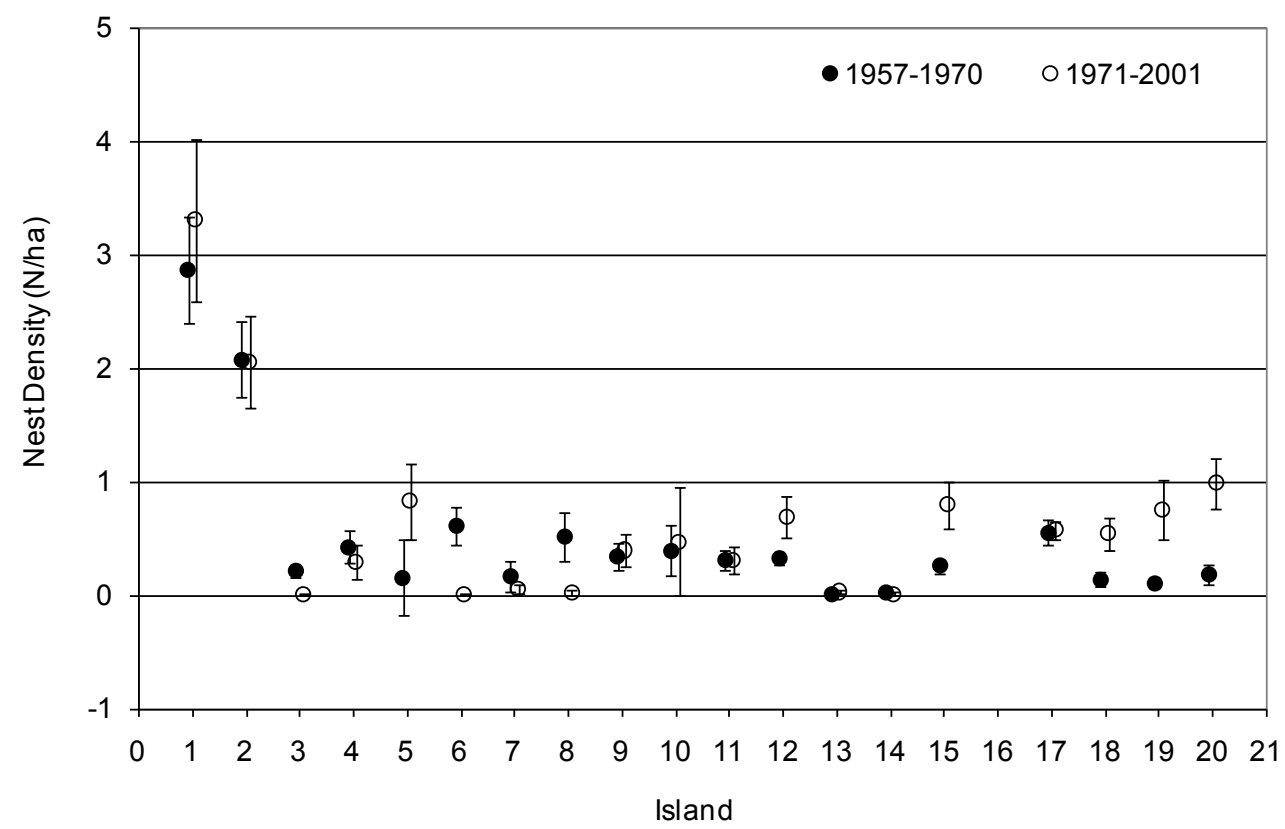

Figure 2.3. Mean Nesting Density for Canada Geese on Islands in the Hanford Reach, Columbia River, for 1957-1970 and 1971-2001. Error bars are $\pm 95 \%$ confidence intervals. 
Table 2.3. Percentage of Canada Goose Nests Classified as Successful, Predated, Abandoned, Flooded, or Fate Unknown for Upper and Lower Islands in the Hanford Reach, Columbia River. Limited surveys in 1959 and 1997 did not allow nesting success to be determined. After 1995, surveys were conducted during alternating years.

\begin{tabular}{|c|c|c|c|c|c|c|c|c|c|c|c|c|}
\hline \multirow[b]{2}{*}{ Year } & \multicolumn{6}{|c|}{ Upper Islands (1 through 10) } & \multicolumn{6}{|c|}{ Lower Islands (11 through 20) } \\
\hline & $N$ & $\begin{array}{c}\% \\
\text { Succ. }\end{array}$ & $\begin{array}{c}\% \\
\text { Aband. }\end{array}$ & \% Pred. & $\begin{array}{c}\% \\
\text { Flood. }\end{array}$ & $\begin{array}{c}\% \\
\text { Unk. }\end{array}$ & $N$ & $\begin{array}{c}\% \\
\text { Succ. }\end{array}$ & $\begin{array}{c}\% \\
\text { Aband. }\end{array}$ & $\begin{array}{c}\% \\
\text { Pred. }\end{array}$ & $\begin{array}{c}\% \\
\text { Flood. }\end{array}$ & $\begin{array}{c}\% \\
\text { Unk. }\end{array}$ \\
\hline 1957 & 194 & 63.9 & 6.2 & 17.5 & 1.0 & 11.3 & 71 & 59.2 & 14.1 & 18.3 & 0.0 & 8.5 \\
\hline 1958 & 213 & 38.0 & 18.3 & 25.8 & 0.0 & 17.8 & 94 & 69.1 & 19.1 & 5.3 & 0.0 & 6.4 \\
\hline 1959 & 160 & & & & & & 35 & & & & & \\
\hline 1960 & 185 & 64.3 & 7.6 & 10.3 & 2.2 & 15.7 & 61 & 75.4 & 9.8 & 4.9 & 0.0 & 9.8 \\
\hline 1961 & 170 & 85.9 & 2.9 & 5.9 & 0.6 & 4.7 & 61 & 85.2 & 11.5 & 1.6 & 1.6 & 0.0 \\
\hline 1962 & 124 & 75.8 & 2.4 & 12.1 & 1.6 & 8.1 & 46 & 73.9 & 6.5 & 0.0 & 0.0 & 19.6 \\
\hline 1963 & 166 & 65.7 & 4.8 & 2.4 & 0.0 & 27.1 & 60 & 61.7 & 13.3 & 1.7 & 0.0 & 23.3 \\
\hline 1964 & 126 & 84.1 & 2.4 & 6.3 & 0.0 & 7.1 & 40 & 65.0 & 12.5 & 0.0 & 0.0 & 22.5 \\
\hline 1965 & 95 & 31.6 & 28.4 & 11.6 & 1.1 & 27.4 & 35 & 60.0 & 11.4 & 0.0 & 0.0 & 28.6 \\
\hline 1966 & 170 & 72.9 & 18.2 & 5.9 & 0.0 & 2.9 & 72 & 77.8 & 15.3 & 4.2 & 0.0 & 2.8 \\
\hline 1967 & 117 & 47.9 & 14.5 & 31.6 & 0.0 & 6.0 & 70 & 75.7 & 17.1 & 7.1 & 0.0 & 0.0 \\
\hline 1968 & 103 & 64.1 & 11.7 & 20.4 & 3.9 & 0.0 & 67 & 76.1 & 19.4 & 3.0 & 0.0 & 1.5 \\
\hline 1969 & 104 & 81.7 & 1.9 & 8.7 & 3.8 & 3.8 & 63 & 76.2 & 9.5 & 14.3 & 0.0 & 0.0 \\
\hline 1970 & 57 & 59.6 & 7.0 & 26.3 & 0.0 & 7.0 & 62 & 79.0 & 8.1 & 4.8 & 0.0 & 8.1 \\
\hline 1971 & 54 & 81.5 & 0.0 & 0.0 & 3.7 & 14.8 & 59 & 71.2 & 6.8 & 0.0 & 5.1 & 16.9 \\
\hline 1972 & 68 & 73.5 & 1.5 & 19.1 & 0.0 & 5.9 & 89 & 86.5 & 4.5 & 6.7 & 0.0 & 2.2 \\
\hline 1973 & 53 & 84.9 & 3.8 & 7.5 & 0.0 & 3.8 & 77 & 79.2 & 7.8 & 5.2 & 0.0 & 7.8 \\
\hline 1974 & 59 & 32.2 & 6.8 & 45.8 & 1.7 & 13.6 & 88 & 63.6 & 11.4 & 10.2 & 3.4 & 11.4 \\
\hline 1975 & 37 & 64.9 & 0.0 & 13.5 & 0.0 & 21.6 & 77 & 76.6 & 14.3 & 2.6 & 0.0 & 6.5 \\
\hline 1976 & 49 & 77.6 & 2.0 & 4.1 & 0.0 & 16.3 & 63 & 71.4 & 12.7 & 9.5 & 0.0 & 6.3 \\
\hline 1977 & 33 & 3.0 & 0.0 & 63.6 & 0.0 & 33.3 & 93 & 75.3 & 5.4 & 10.8 & 0.0 & 8.6 \\
\hline 1978 & 53 & 83.0 & 1.9 & 5.7 & 0.0 & 9.4 & 85 & 71.8 & 5.9 & 16.5 & 0.0 & 5.9 \\
\hline 1979 & 37 & 81.1 & 2.7 & 5.4 & 0.0 & 10.8 & 96 & 71.9 & 9.4 & 7.3 & 0.0 & 11.5 \\
\hline 1980 & 40 & 77.5 & 7.5 & 12.5 & 0.0 & 2.5 & 115 & 60.0 & 20.0 & 7.0 & 0.9 & 12.2 \\
\hline 1981 & 44 & 77.3 & 2.3 & 15.9 & 0.0 & 4.5 & 113 & 79.6 & 11.5 & 5.3 & 0.0 & 3.5 \\
\hline 1982 & 58 & 93.1 & 0.0 & 5.2 & 0.0 & 1.7 & 114 & 73.7 & 14.9 & 7.0 & 0.9 & 3.5 \\
\hline 1983 & 78 & 52.6 & 1.3 & 26.9 & 0.0 & 19.2 & 149 & 69.8 & 8.1 & 6.7 & 0.7 & 14.8 \\
\hline 1984 & 71 & 64.8 & 0.0 & 8.5 & 0.0 & 26.8 & 131 & 59.5 & 11.5 & 5.3 & 0.8 & 22.9 \\
\hline 1985 & 60 & 71.7 & 0.0 & 26.7 & 0.0 & 1.7 & 133 & 85.7 & 7.5 & 2.3 & 0.0 & 4.5 \\
\hline 1986 & 52 & 92.3 & 1.9 & 1.9 & 0.0 & 3.8 & 116 & 89.7 & 5.2 & 0.0 & 1.7 & 3.4 \\
\hline 1987 & 72 & 80.6 & 2.8 & 9.7 & 6.9 & 0.0 & 176 & 68.8 & 14.2 & 6.8 & 3.4 & 6.8 \\
\hline 1988 & 21 & 14.3 & 0.0 & 76.2 & 0.0 & 9.5 & 194 & 74.2 & 9.8 & 5.2 & 0.5 & 10.3 \\
\hline 1989 & 69 & 65.2 & 0.0 & 21.7 & 4.3 & 8.7 & 195 & 76.4 & 3.1 & 2.6 & 3.6 & 14.4 \\
\hline 1990 & 68 & 77.9 & 1.5 & 8.8 & 2.9 & 8.8 & 185 & 76.2 & 3.2 & 3.2 & 7.6 & 9.7 \\
\hline 1991 & 96 & 78.1 & 0.0 & 9.4 & 5.2 & 7.3 & 220 & 76.8 & 6.8 & 2.7 & 4.5 & 9.1 \\
\hline
\end{tabular}


Table 2.3. (contd)

\begin{tabular}{|c|c|c|c|c|c|c|c|c|c|c|c|c|}
\hline \multirow[b]{2}{*}{ Year } & \multicolumn{6}{|c|}{ Upper Islands (1 through 10) } & \multicolumn{6}{|c|}{ Lower Islands (11 through 20) } \\
\hline & $N$ & $\begin{array}{c}\% \\
\text { Succ. }\end{array}$ & $\begin{array}{c}\% \\
\text { Aband. }\end{array}$ & $\%$ Pred. & $\begin{array}{c}\% \\
\text { Flood. }\end{array}$ & $\begin{array}{c}\% \\
\text { Unk. }\end{array}$ & $N$ & $\begin{array}{c}\% \\
\text { Succ. }\end{array}$ & $\begin{array}{c}\% \\
\text { Aband. }\end{array}$ & $\begin{array}{c}\% \\
\text { Pred. }\end{array}$ & $\begin{array}{c}\% \\
\text { Flood. }\end{array}$ & $\begin{array}{c}\% \\
\text { Unk. }\end{array}$ \\
\hline 1992 & 77 & 61.0 & 1.3 & 29.9 & 0.0 & 7.8 & 210 & 79.0 & 4.3 & 5.2 & 3.3 & 8.1 \\
\hline 1993 & 28 & 64.3 & 0.0 & 14.3 & 0.0 & 21.4 & 207 & 86.0 & 0.5 & 4.8 & 0.0 & 8.7 \\
\hline 1994 & 27 & 77.8 & 0.0 & 14.8 & 3.7 & 3.7 & 154 & 85.7 & 0.6 & 0.6 & 7.8 & 5.2 \\
\hline 1995 & 42 & 35.7 & 0.0 & 47.6 & 4.8 & 11.9 & 204 & 66.7 & 3.9 & 8.8 & 7.8 & 12.7 \\
\hline \multicolumn{13}{|l|}{1997} \\
\hline 1999 & 53 & 86.8 & 0.0 & 11.3 & 0.0 & 1.9 & 190 & 80.0 & 4.2 & 6.8 & 2.1 & 6.8 \\
\hline 2001 & 29 & 75.9 & 3.4 & 20.7 & 0.0 & 0.0 & 199 & 82.4 & 9.0 & 4.5 & 0.0 & 4.0 \\
\hline Mean & 81.3 & $66.6^{(\mathrm{a})}$ & $4.2^{(\mathrm{b})}$ & $17.8^{(\mathrm{c})}$ & 1.2 & 10.2 & 113.4 & $74.3^{(a)}$ & $9.6^{(\mathrm{b})}$ & $5.5^{(\mathrm{c})}$ & 1.4 & 9.2 \\
\hline Min. & 21.0 & 3.0 & 0.0 & 0.0 & 0.0 & 0.0 & 35.0 & 59.2 & 0.5 & 0.0 & 0.0 & 0.0 \\
\hline Max & 213.0 & 93.1 & 28.4 & 76.2 & 6.9 & 33.3 & 220.0 & 89.7 & 20.0 & 18.3 & 7.8 & 28.6 \\
\hline
\end{tabular}

(a) Means with same letters are significantly different at $P=<0.05$ between upper and lower island groups.

(b) Means with same letters are significantly different at $P=<0.05$ between upper and lower island groups.

(c) Means with same letters are significantly different at $P=<0.05$ between upper and lower island groups.

The fate of the nests also varied by island group; the percentage of successful nests generally was higher on the lower islands compared to the upper islands (Table 2.3 ). Overall, nearly $75 \%$ of the nests on the lower islands were successful compared to $67 \%$ on the upper islands (Table 2.3). In addition to the significant difference in percentage of successful nests between upper and lower island groups $(P=0.03)$, what is most striking is the variability in nesting success on the upper islands (3-93\%) compared to the lower islands (59-90\%). On the upper islands, for those nests where the fate was known, predation was the primary factor impacting Canada goose nests; more than $17 \%$ of the nests were destroyed by predators compared to $5 \%$ on the lower islands (significant at $P<0.001$ ). On the other hand, there were significantly more abandoned nests on the lower islands compared to the upper islands $(P<0.001)$ (Table 2.3). Flooding appears to have had a minimal impact on Canada goose nests with, on average, only $1 \%$ of the nests flooded on either the upper or lower islands. Flooding had a slightly higher impact on the lower islands from 1990 through 1995, but there was no significant difference in the number of nests flooded. There was also no significant difference between the island groups $(P=0.67)$ in the number of nests where the fate was undetermined $(P=0.48)$.

In addition to nesting success, clutch size and hatching rate also are important in documenting the health of a population. For Canada geese in the Hanford Reach, average clutch size varied from 5.0 eggs/nest on the upper islands to 5.9 eggs/nest on the lower islands (Figure 2.4). Within the islands, Canada geese nesting on Island 10 had the lowest clutch size $(4.7 \pm 1.7)$, while those nesting on Island 15 had the largest clutch size $(6.1 \pm 0.7)$. Clutch size varied also with survey date; the nests found in the latter part of March had significantly larger clutches (mean $=6.4$ eggs $/$ nest) than those found in the first part of May (mean $=4.8$ eggs/nest) $(P<0.001)$ (Figure 2.5). 


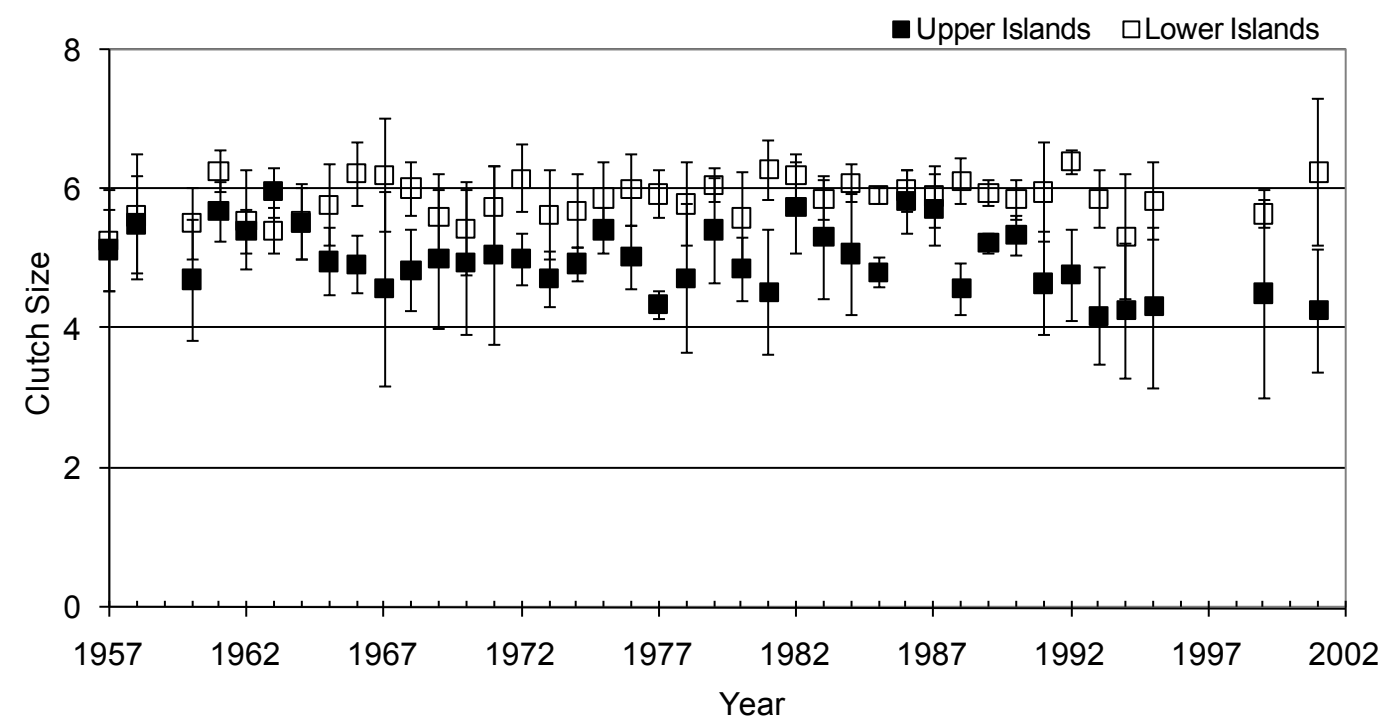

Figure 2.4. Number of Canada Goose Eggs per Nest (Clutch Size) for Upper Islands (1 through 10) and Lower Islands (11 through 20) in the Hanford Reach, Columbia River. Error bars are $\pm 95 \%$ confidence intervals.

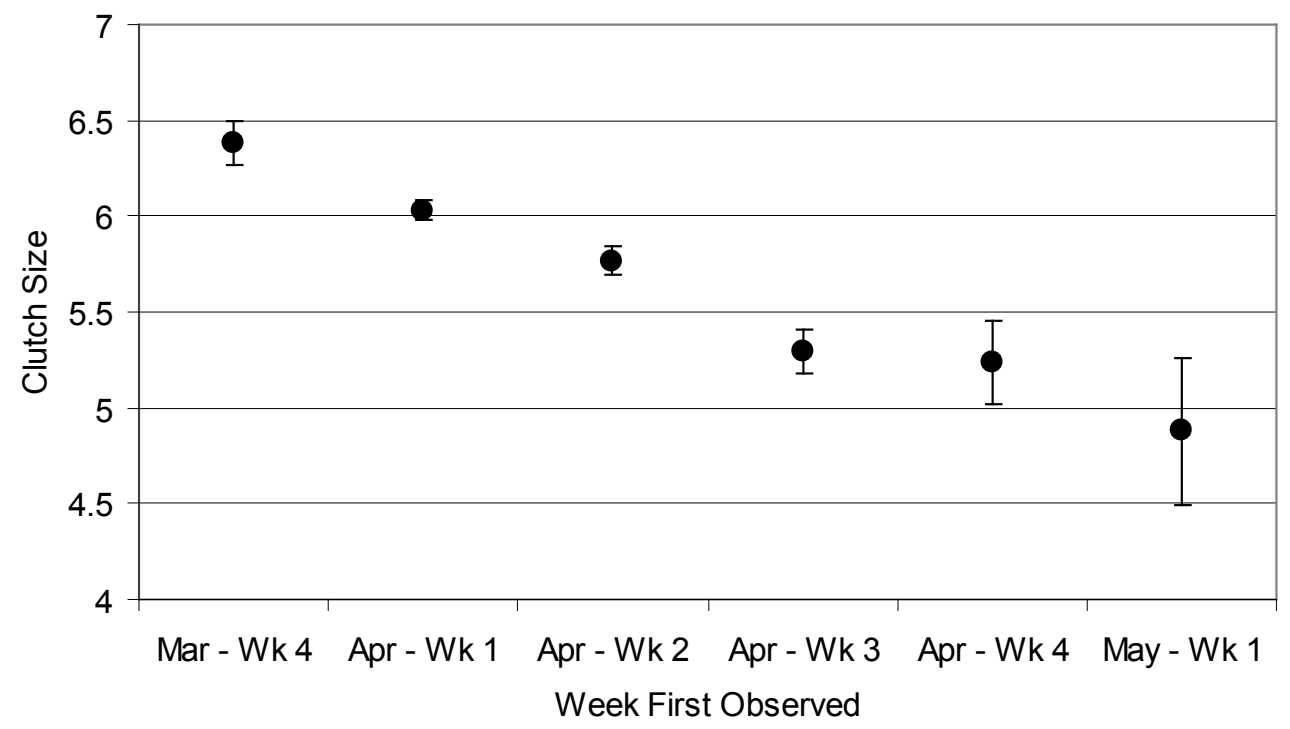

Figure 2.5. Clutch Size for Canada Goose Nests on Islands in the Hanford Reach as a Function of Date First Observed. Error bars are 95\% confidence intervals. Samples sizes: 448 (Mar - Wk 4); 2708 (Apr - Wk 1); 1332 (Apr - Wk 2); 562 (Apr - Wk 3); 188 (Apr - Wk 4); 65 (May - Wk 1).

Hatching rates for Canada geese increased over the study period. Rates in the early years were less than $90 \%$, while rates in the 1990 s were generally above $90 \%$ (Figure 2.6). These rates were based on the total number of eggs recorded in a nest and included eggs that were predated, abandoned, or of unknown fate and, as such, are a conservative estimate. If nests are considered only where the fate of all eggs was 
known, then the hatching rate is nearly $95 \%$ (range $88 \%$ to $100 \%$ ). There appears to be little consistent difference between island groups in hatching rate, with upper and lower islands having similar rates since the late 1980s.

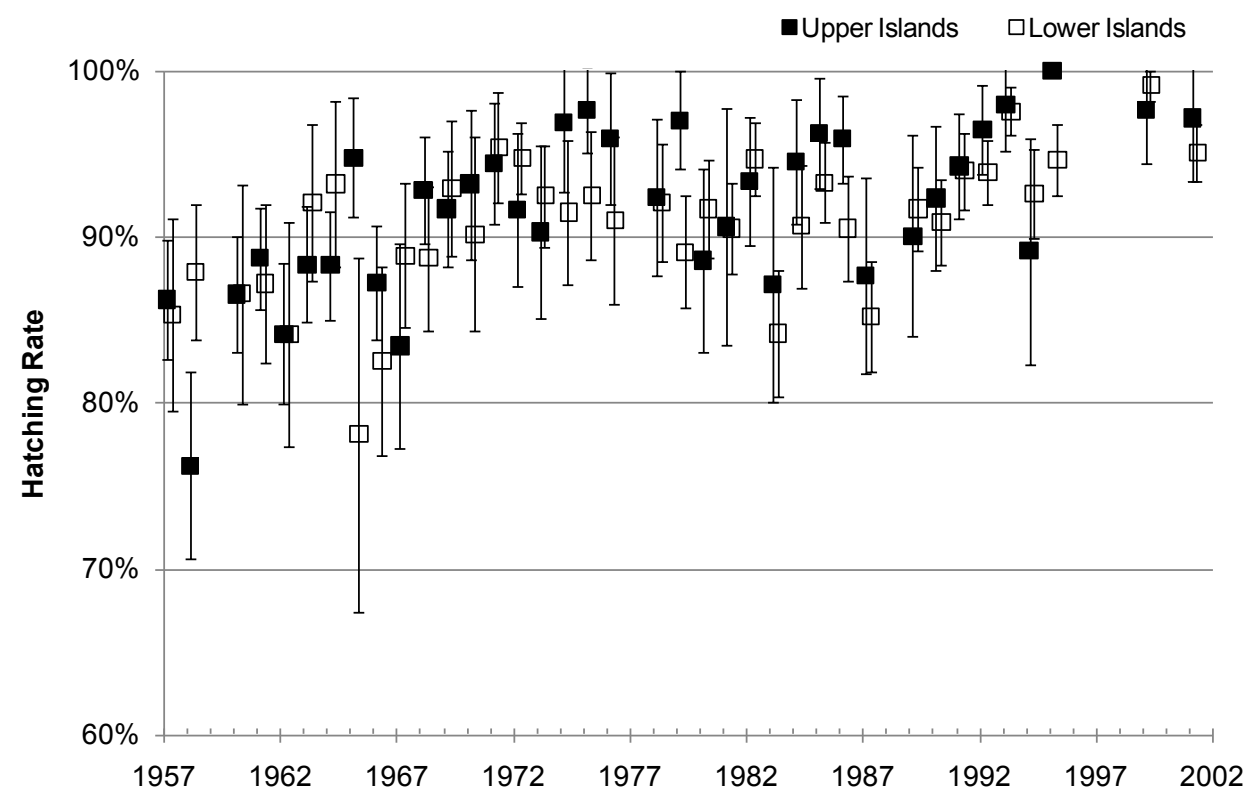

Figure 2.6. Hatching Rate for Successful Nests on Upper Islands (1 through 10) and Lower Islands (11 through 20) on the Hanford Reach, Columbia River. Data for 1977 and 1988 were excluded because of low sample sizes for upper islands $(1977, N=1 ; 1988, N=3)$; a special study in 1959 did not collect data to calculate hatching rate. Error bars are $\pm 95 \%$ confidence intervals.

\subsection{Discussion}

The health of the Canada goose population along the Hanford Reach has been monitored for the past 50 years for both management and radioecological purposes; many of the health measurements are centered around nesting activity. Nesting fate is a practical measurement for geese in this area where measurements reveal the relative impacts from the primary forces regulating the nesting population (flooding and predation). Clutch size also is an important biological indicator of pollution (Eeva and Lehikoinen 1995; Bustnes et al. 2003) and could potentially document any deleterious effects related to Hanford Site operations.

The primary change in nesting activity along the Hanford Reach has been the shift in the distribution of nests from the upper to the lower islands. Predation appears to be the primary driver for this shift, with major predation events observed over the years. Coyotes (Canis latrans) are a primary predator on the upper islands (Hanson and Eberhardt 1971; Fitzner and Rickard 1983). For example, in 1965, a single coyote on Island 6 (Locke Island) killed 7 geese, destroyed 11 nests, and caused 28 nests to be abandoned (Fitzner and Rickard 1983). In 1977, all nests on Islands 1 and 2 were destroyed by coyotes (DeWaard 1981), while in 1988, a common raven (Corvus corax) predated all 15 nests on Island 2 (Fitzner et al. 1994). In the early 1950s, Hanson and Browning (1959) found magpies (Pica pica) to be a major nest predator destroying all the nests (23) on a single island. 
Much of the decrease in nest numbers on the upper islands is attributable to changes on Island 6 (Locke Island). This is the largest of the 20 islands and, in years prior to the late 1960s, nesting on this island accounted for $30 \%$ of the total number of nests (Table 2.4). The 1965 predation event (see above) was followed by another in 1967 when two resident coyotes destroyed all but one of 21 nests. In 1968 several coyotes were shot and nesting rebounded for several years, but since 1970, coyotes have been more or less permanent residents on the island, with the result that few to no nests have been found.

Periodic coyote control efforts have been attempted in the Hanford Reach (Hanson and Eberhardt 1971; Fitzner and Rickard 1983) but have had little influence on the number of geese nesting on the islands subject to predation pressure.

The increase in predation by coyotes may be related to the change in river flow patterns following the completion of several upstream dams, including Priest Rapids Dam in 1959, Rocky Reach in 1961, Wanapum in 1962, and Wells in 1967. The flow pattern prior to the 1970s was characterized by peak flows in May and June around 350,000 cfs (Figure 2.7). Since the early 1970s, peak flows during the May-June period now average less than $200,000 \mathrm{cfs}$. This change may have allowed coyotes easier and more frequent access to the islands. In addition, lower flows have contributed to a change in the island vegetation, with an increase in the amount of willows and in the proportion of the area that is vegetated (DeWaard 1981). For example, there was only a single nesting attempt on Island 5 before 1978 when six nests were found in 1967. Hansen and Eberhardt (1971) described Island 5 as having a low profile and lacking in nesting cover. In 1981, DeWaard (1981) found more than $70 \%$ of the island vegetated and, since 1978, from 1 to 10 nests have been located on the island.

Although the upper islands are subject to predation, they are generally protected from human disturbance. Even with the lifting of boating restrictions in 1977, the upper islands are still further from population centers. This is not true of the lower islands, which, given their proximity to urban populations, are easily visited by boaters. Human disturbance is probably the primary reason for the higher proportion of abandoned nests on the lower islands compared to that on the upper islands (Hanson and Eberhardt 1971). DeWaard noted that Island 12 had the highest desertion rate of all the islands between 1971 and 1980. The island is adjacent to a fish hatchery, and the area near the hatchery is heavily fished. In 1980, 55\% of the deserted nests were on Island 12. Most of these were deserted over a 4-week period that was coincident with an unusually large spring run of steelhead (DeWaard 1981). In 1987, Fitzner et al. (1994) documented the presence of a fisherman with his dog on Island 17, with the result that more than $40 \%$ of the nests were either destroyed or abandoned.

The temporal change in the distribution of nests in the Hanford Reach is reflected also in the density of nests, with densities generally decreasing on the upper islands and increasing on the lower islands since the 1950s. However, the densities on the two northernmost islands (Islands 1 and 2) have remained high over the 40 years of monitoring and also have the highest density of all the islands (greater than 2 nests/ha). For comparison, Canada geese on Akimiski Island in Canada had a nesting density of 0.12 to 0.32 nests/ha (Leafloor et al. 2000).

Another measure of nesting performance is clutch size. Clutch size is affected by many factors, including latitude (Dunn and MacInnes 1987), the fitness of the female goose (Raveling et al. 2000), initiation date of the nest (Krapu et al. 2004), weather (Dunn and MacInnes 1987), and pollution (Sargeant and Raveling 1992). Clutch size for Canada geese in Canada averaged from 3.5 to 4.6 eggs/nest (Leafloor et al. 2000); Ball et al. (1981) found mean clutch sizes in Washington State to 
range from 5.4 to 6.2 eggs/nest. In the Hanford Reach, clutch sizes were smaller on the upper islands (mean 5.0 eggs/nest) compared to the lower islands (mean 5.9 eggs/nest). DeWaard (1981) suggested the difference in clutch size between upper and lower islands was due to crowding. This may be a factor, as Islands 1 and 2 have the highest densities and among the lowest clutch sizes.

Table 2.4. Number of Canada Goose Nests on All Islands and on Island 6 in the Hanford Reach of the Columbia River for the Survey Period

\begin{tabular}{|c|c|c|c|c|c|c|}
\hline \multirow[b]{2}{*}{ Survey Year } & \multicolumn{3}{|c|}{ Total Nests } & \multicolumn{3}{|c|}{ Successful Nests } \\
\hline & All Islands & Island 6 & $\%$ & All Islands & Island 6 & $\%$ \\
\hline 1957 & 265 & 122 & 46.0 & 166 & 76 & 45.8 \\
\hline 1958 & 307 & 108 & 35.2 & 146 & 50 & 34.2 \\
\hline $1959^{(\mathrm{a})}$ & 195 & 104 & 53.3 & & & \\
\hline 1960 & 246 & 97 & 39.4 & 165 & 64 & 38.8 \\
\hline 1961 & 231 & 97 & 42.0 & 198 & 87 & 43.9 \\
\hline 1962 & 170 & 69 & 40.6 & 128 & 58 & 45.3 \\
\hline 1963 & 226 & 103 & 45.6 & 146 & 66 & 45.2 \\
\hline 1964 & 166 & 84 & 50.6 & 132 & 72 & 54.5 \\
\hline 1965 & 130 & 47 & 36.2 & 51 & 3 & 5.9 \\
\hline 1966 & 242 & 85 & 35.1 & 180 & 64 & 35.6 \\
\hline 1967 & 187 & 21 & 11.2 & 109 & 1 & 0.9 \\
\hline 1968 & 170 & 40 & 23.5 & 117 & 30 & 25.6 \\
\hline 1969 & 167 & 52 & 31.1 & 133 & 47 & 35.3 \\
\hline 1970 & 119 & 3 & 2.5 & 83 & 0 & 0.0 \\
\hline 1971 & 113 & 10 & 8.8 & 86 & 8 & 9.3 \\
\hline 1972 & 157 & 9 & 5.7 & 127 & 2 & 1.6 \\
\hline 1973 & 130 & 1 & 0.8 & 106 & 1 & 0.9 \\
\hline 1974 & 147 & 0 & 0.0 & 75 & 0 & 0.0 \\
\hline 1975 & 114 & 5 & 4.4 & 83 & 0 & 0.0 \\
\hline 1976 & 112 & 0 & 0.0 & 83 & 0 & 0.0 \\
\hline 1977 & 126 & 0 & 0.0 & 71 & 0 & 0.0 \\
\hline 1978 & 138 & 1 & 0.7 & 105 & 0 & 0.0 \\
\hline 1979 & 133 & 0 & 0.0 & 99 & 0 & 0.0 \\
\hline 1980 & 155 & 0 & 0.0 & 100 & 0 & 0.0 \\
\hline 1981 & 157 & 0 & 0.0 & 124 & 0 & 0.0 \\
\hline 1982 & 172 & 9 & 5.2 & 138 & 8 & 5.8 \\
\hline 1983 & 227 & 3 & 1.3 & 145 & 0 & 0.0 \\
\hline 1984 & 202 & 0 & 0.0 & 124 & 0 & 0.0 \\
\hline 1985 & 193 & 0 & 0.0 & 157 & 0 & 0.0 \\
\hline 1986 & 168 & 0 & 0.0 & 152 & 0 & 0.0 \\
\hline 1987 & 248 & 0 & 0.0 & 179 & 0 & 0.0 \\
\hline 1988 & 215 & 0 & 0.0 & 147 & 0 & 0.0 \\
\hline 1989 & 264 & 1 & 0.4 & 194 & 0 & 0.0 \\
\hline 1990 & 253 & 0 & 0.0 & 194 & 0 & 0.0 \\
\hline 1991 & 316 & 0 & 0.0 & 244 & 0 & 0.0 \\
\hline
\end{tabular}


Table 2.4. (contd)

\begin{tabular}{lcccccc}
\hline & \multicolumn{3}{c}{ Total Nests } & \multicolumn{3}{c}{ Successful Nests } \\
\cline { 2 - 7 } Survey Year & All Islands & Island 6 & $\%$ & All Islands & Island 6 & $\%$ \\
\hline 1992 & 287 & 0 & 0.0 & 213 & 0 & 0.0 \\
1993 & 235 & 0 & 0.0 & 196 & 0 & 0.0 \\
1994 & 181 & 0 & 0.0 & 153 & 0 & 0.0 \\
1995 & 246 & 0 & 0.0 & 151 & 0 & 0.0 \\
1999 & 243 & 0 & 0.0 & 198 & 0 & 0.0 \\
2001 & 228 & 0 & 0.0 & 186 & 0 & 0.0 \\
\hline
\end{tabular}

(a) Limited number of surveys; nesting success not determined.

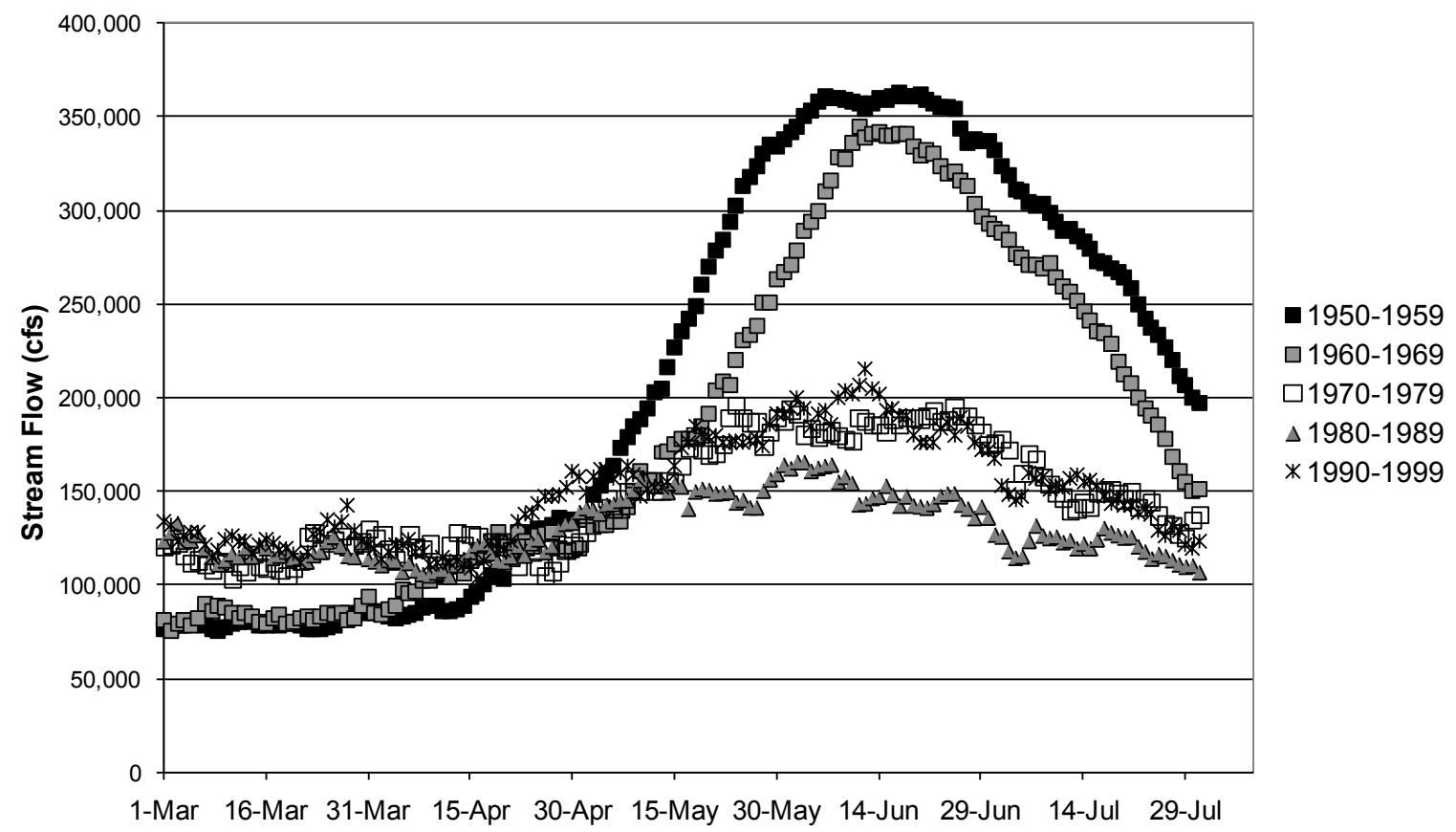

Figure 2.7. Daily Average Stream Flow in Cubic Feet per Second (cfs) Monitored on the Columbia River Downstream from Priest Rapids Dam. Source: DART (2008).

An additional factor affecting clutch size is the nest initiation date (Krapu et al. 2004). For Canada geese nesting along the Hanford Reach, clutch size decreased from an average 6.4 eggs/nest for nests located the last week of March to 4.9 eggs/nest for nests located by the first week of May (Figure 2.5). Krapu et al. (2004) conjectured that large early clutches are adaptive because of higher survival of early hatched young. In other studies, clutch size appears to be strongly related to the fitness of the female goose, and Raveling et al. (2000) noted that about $17 \%$ of the breeding-age geese raise $50 \%$ of the young, with aggressiveness positively related to nesting and brood-rearing success. In the Columbia Basin, early nesting females may be local birds that have spent the winter feeding on local fields and therefore may be larger than birds migrating to the area. The change in clutch size may also reflect re-nesting after losing the initial nest. The female would have fewer resources for the next clutch. However, without marking individual adults, the reason for the decline in clutch size is speculative. 
Clutch size appears to be correlated also to the number of surveys (Table 2.5). The number of surveys was generally similar between upper and lower islands; however, there was a shift over the years in the number of surveys conducted each season. Before 1970, the nests were surveyed weekly; this shifted to biweekly in 1971. The highest and least-variable clutch size was associated with between three and five surveys per nest (once the nest was established). Hatching rate was also correlated to the number of surveys; the longer time interval between surveys makes an accurate assessment of egg fates more difficult. The highest hatching rates were associated with nests that were visited a minimum of four times. In the late 1950s and 1960s, the average number of visits was over six; this fell to less than four in the late 1970s. More surveys were carried out in the 1980s (average 5.5 to 6 ) but fell again in the 1990s to around 4.25. The longer time between visits increased the uncertainty on the fate of eggs and adds another factor to the attempt to determine the cause for the fluctuations in clutch size and hatching rate.

Table 2.5. Clutch Size and Hatching Proportion as a Function of Number of Surveys to a Nest Once Eggs Were Present. Data only for successful nests where the fate of eggs was known.

\begin{tabular}{lccccc}
\hline \multirow{2}{*}{$\begin{array}{c}\text { Number of } \\
\text { Surveys }\end{array}$} & \multirow{2}{*}{$\begin{array}{c}\text { Number of } \\
\text { Nests }\end{array}$} & Mean & Std. Dev. & Mean & Std. Dev. \\
\cline { 3 - 6 } 1 & 223 & 3.6 & 1.96 & 0.18 & 0.379 \\
2 & 1716 & 5.4 & 1.77 & 0.60 & 0.466 \\
3 & 2369 & 5.8 & 1.44 & 0.80 & 0.360 \\
4 & 1427 & 5.8 & 1.42 & 0.86 & 0.282 \\
5 & 499 & 5.8 & 1.30 & 0.83 & 0.291 \\
6 & 119 & 5.9 & 1.70 & 0.77 & 0.333 \\
7 & 16 & 5.9 & 1.89 & 0.36 & 0.463 \\
8 & 1 & 6.0 & 0.00 & 1.00 & 0.000 \\
Total & 6370 & 5.6 & 1.60 & 0.74 & 0.401 \\
\hline
\end{tabular}

Weather also can affect clutch size. An analysis of various weather factors, including the number of days below freezing, precipitation, and minimum temperatures, found the number of March days below freezing had a slight negative impact on clutch size. However, weather, especially in the Columbia Basin, probably has a lesser impact on clutch size than on brood survival, especially on prefledged young (Sargeant and Raveling 1992). On the other hand, a cool early spring could affect female weight, with more energy expended in staying warm than on egg production.

In general, the islands of the Hanford Reach have provided good habitat for Canada geese nesting over the past 50 years. This is evidenced by an average of nearly 200 nests per year and a hatching success rate of more than 70\%. Spatial and temporal changes in Canada goose nesting appear to be related more to changes in the dynamics of the predator population than to Hanford Site operations. 


\subsection{Goose Banding Studies}

Canada geese using the Hanford Site are distributed widely in areas west of the Continental Divide (Terres 1980). Some populations migrate from northern Mexico and the U.S. Southwest to nest in the Pacific Northwest and southern Canada (Terres 1980), while breeding populations from Canada may winter in the Pacific Northwest or continue further south. However, not all populations migrate, and resident populations exist along the Columbia River. These populations, especially the nesting birds, have been monitored over the past 50 years to evaluate possible impacts from Hanford Site activities. Although one of the main focuses of monitoring Canada geese at the site has been nesting success, geese also were banded to determine the distribution of the birds after nesting and fledging. Geese that remained in the area would be expected to have increased potential exposure to Hanford Site contaminants, whereas migrating birds could be exposed to different contaminants during migration.

\subsection{Methods}

Banding studies began in 1950, with a total of 3430 geese banded between 1950 and 1994. The initial banding study between 1950 and 1970 was conducted with the Washington Department of Fish and Wildlife under its Federal permit. In 1983, banding was resumed under a PNNL permit and continued until 1994.

Birds were captured for banding approximately 6 to 8 weeks after hatching was completed. Two methods were used to capture birds: one involved herding the birds toward traps, and the second (and more successful method) involved surrounding and capturing the birds by hand (termed freebanding). A more complete description of banding methods is found in Hanson and Eberhardt (1971).

Banding and recovery data were obtained from the U.S. Geological Survey (USGS) Bird Banding Laboratory (2006a). Banding and recoveries for 1950 through 1970 were compared to Hanson and Eberhardt (1971), while data for 1983 through 1994 were checked against our laboratory records. Discrepancies in banding numbers between those reported in Hanson and Eberhardt (1971) and the records supplied by the Banding Laboratory were few and had a minor impact on the overall recovery rates. Recovery rates are expressed as the ratio of the bands recovered to the total number of geese banded; distances were calculated with the Haversine formula (Sinnott 1984), used in navigation to give distances between two points on a sphere.

\subsection{Results}

A total of 1009 adults (birds more than 1 year old) and 2421 goslings or juveniles were banded from 1950 through 1994. Banding was done yearly between 1950 and 1970, except for 1967. Banding resumed in 1983 and continued intermittently until 1994 (no banding was conducted in 1985, 1986, or 1992). More than 1400 banded geese were recovered, resulting in a banding recovery of approximately $30 \%$. There were no significant differences $(P<0.05)$ in recovery rates between adults and juveniles (Figure 3.1) or in number of years post-banding (Figure 3.2). More than $50 \%$ of the recoveries occurred 
within 3 years of banding, with few birds recovered beyond 10 years (Figure 3.3). A single bird was recovered after 24 years. According to the USGS, the record for band recovery for Canada geese is 30 years (USGS 2006b).

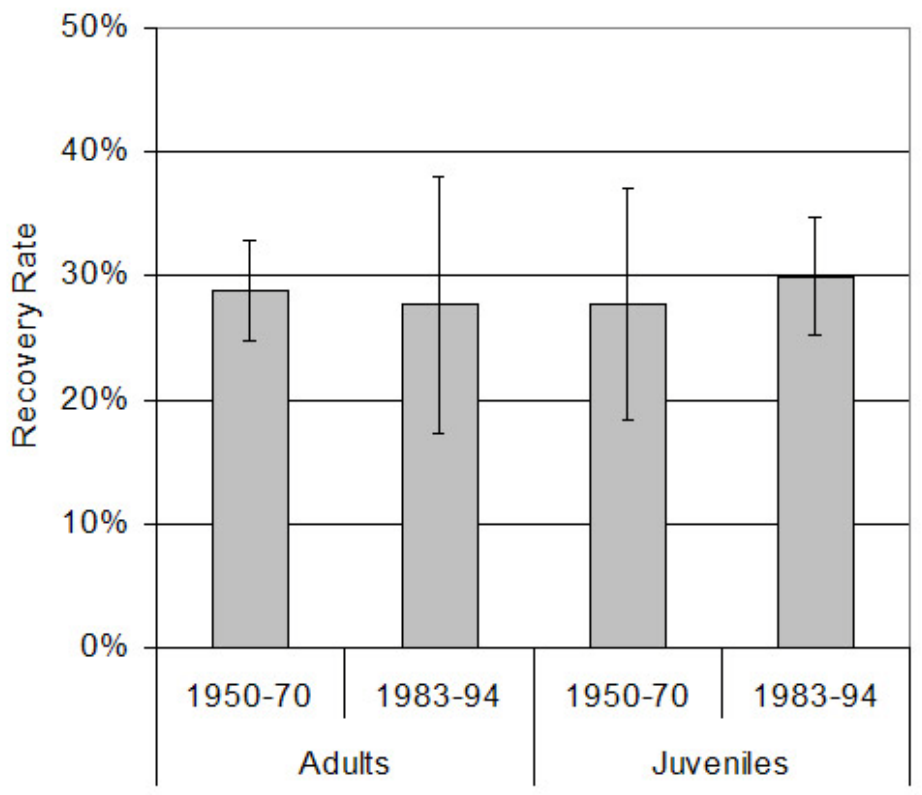

Figure 3.1. Recovery Rates for Adult and Juvenile Canada Geese Banded Either 1950-1970 or 1983-1994. Bars represent 95\% confidence intervals.

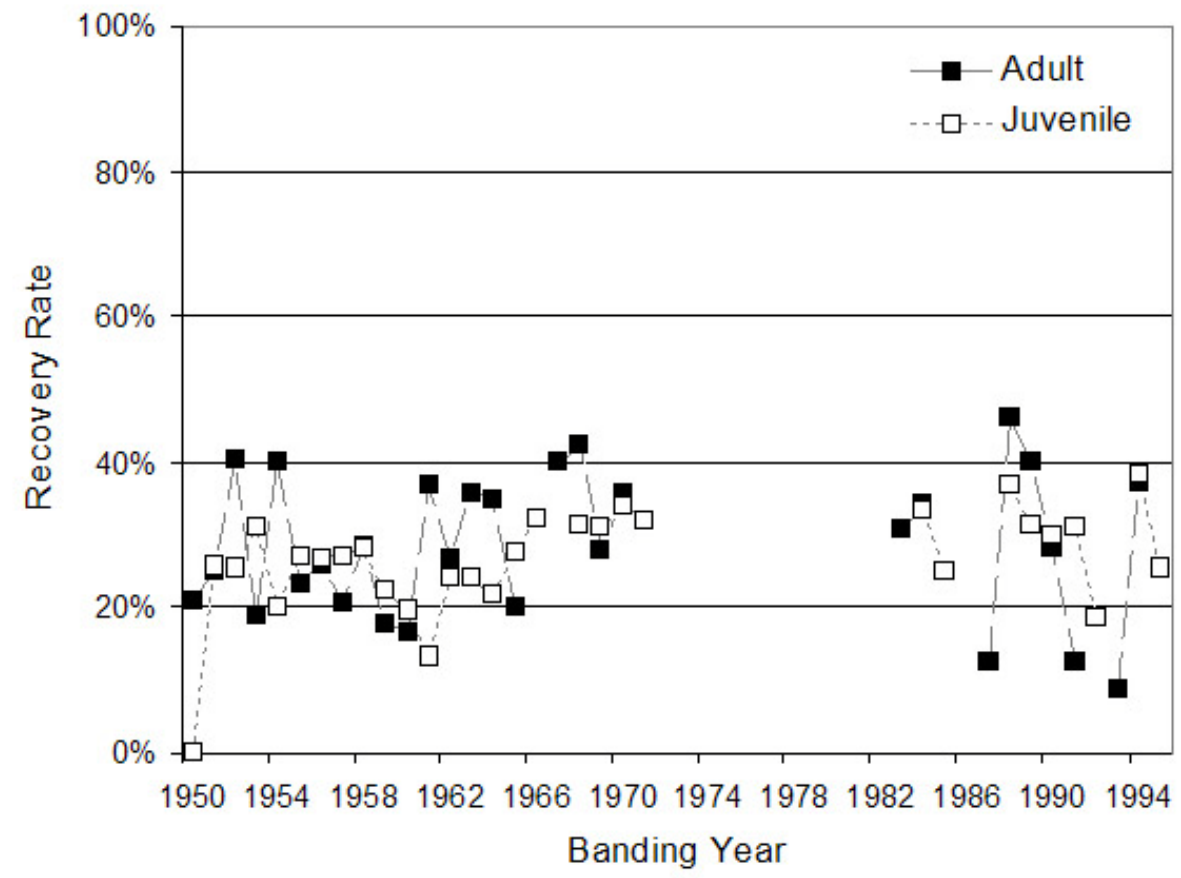

Figure 3.2. Recovery Rate for Canada Geese by Banding Year and Age at Banding 


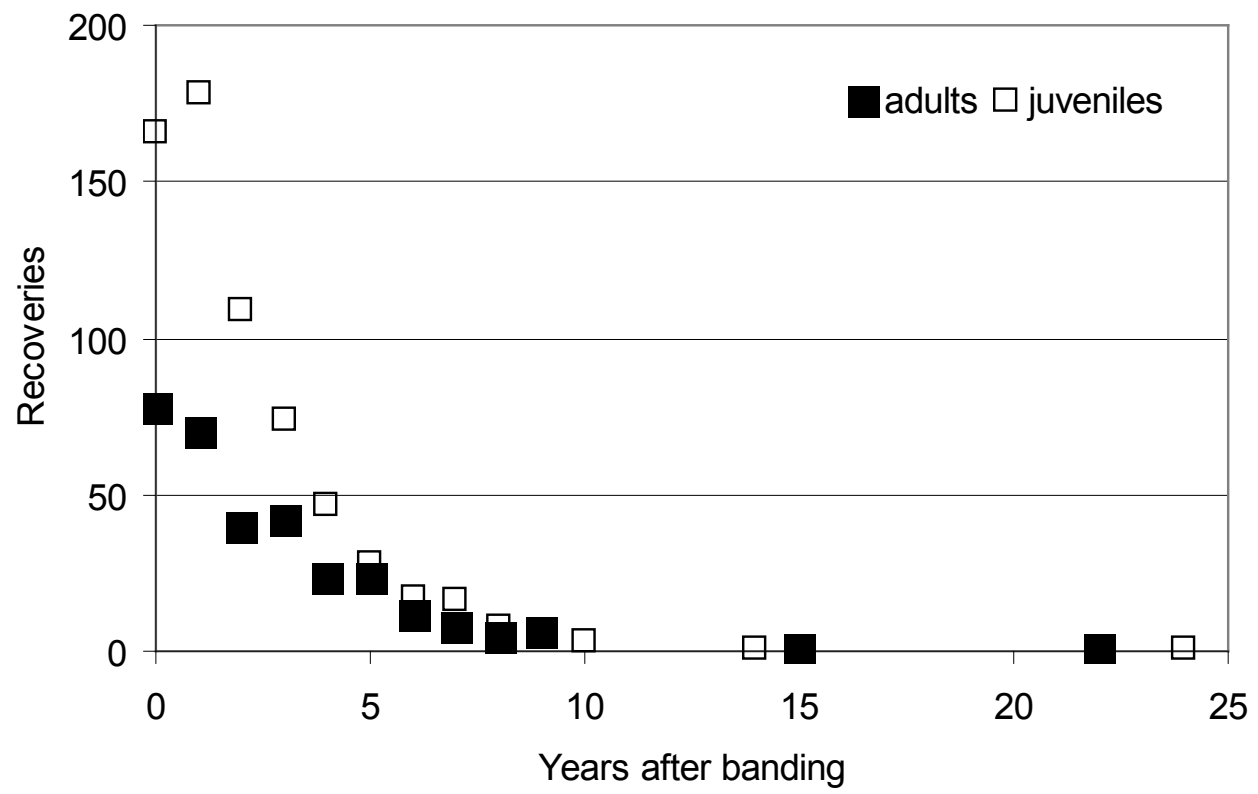

Figure 3.3. Number of Canada Geese Recovered as a Function of Years Since Banding and Age at Banding (adults more than 1 year; juveniles less than 1 year)

The distribution of recoveries (Figure 3.4, Table 3.1) indicates that more than $60 \%$ of the Canada geese were recovered locally (i.e., within $80 \mathrm{~km}$ ). A chi-square test of association within each age group was significant $(P<0.01)$, indicating an association between banding year and recovery distance. In general, the percentage of birds remaining locally increased from less than $60 \%$ in the 1950 s to more than $70 \%$ in the 1980s. In addition, there were differences in recoveries for geese banded as adult versus those banded as juveniles. For birds banded as juveniles, 90\% were recovered locally the first year. This dropped to $40 \%$ the following year for the now-adult birds, and after 3 years, recoveries of these juvenilebanded geese were again predominantly local.

\subsection{Discussion}

The banding and recovery of Canada geese in the Columbia Basin has taken place for over 50 years. During that time, major changes have occurred, including the addition of multiple dams on the river, both upstream and downstream of the Hanford Site, and the shift from a primarily agrarian area with small farms to a medium-sized urban area surrounded by large irrigated agricultural areas. In addition, activities at the Hanford Site have changed from the production of plutonium for national defense and management of the resulting wastes to cleanup of the reactor and processing facilities and associated waste sites. The banding studies provide information on the distribution of geese that nest or hatched in the Hanford Reach. This information, along with the contaminant burden of the geese (Section 4) could be used to evaluate the potential distribution of Hanford Site contaminants. 


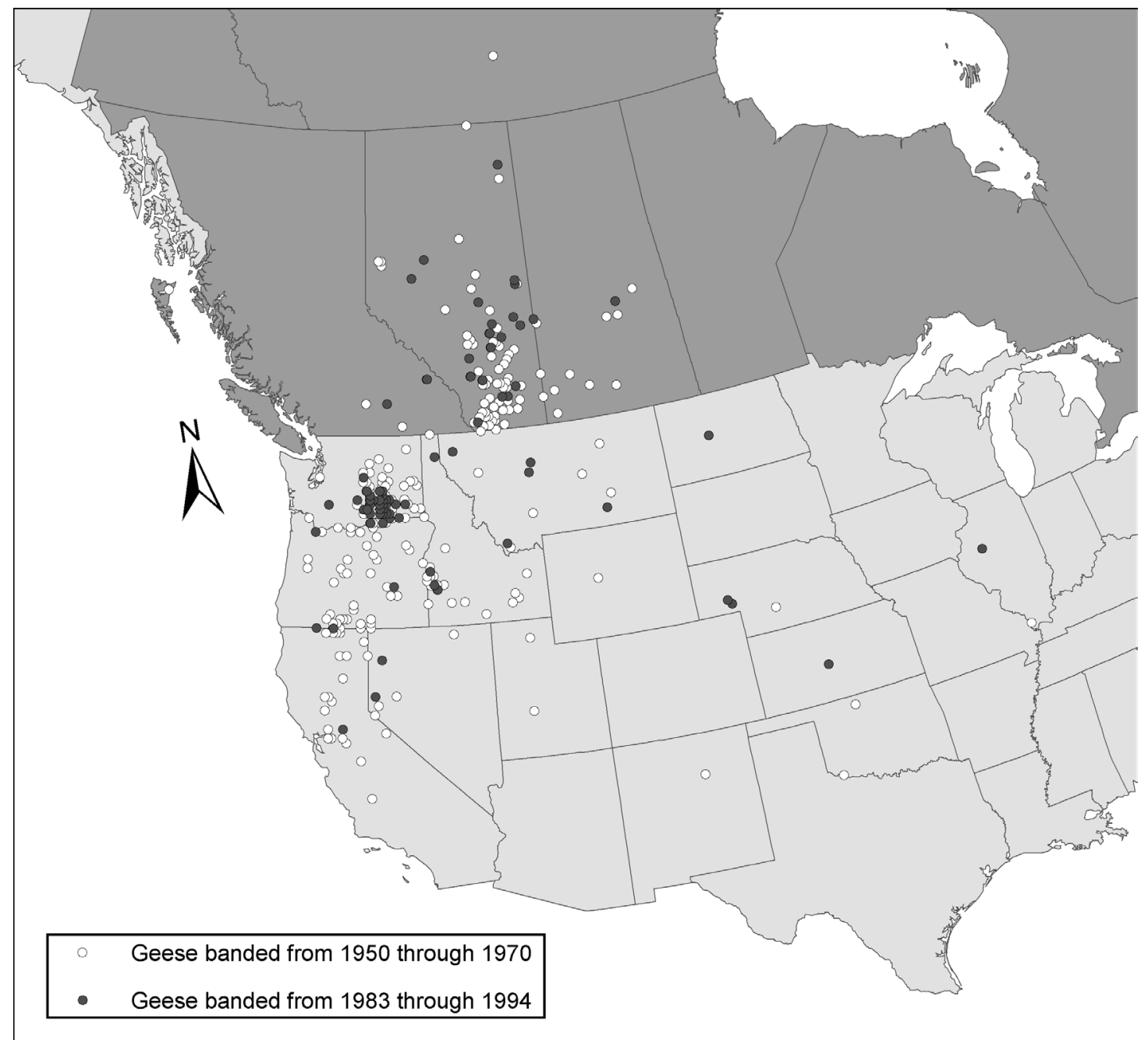

Figure 3.4. Distribution of Recoveries of Canada Geese Banded in Hanford Reach Vicinity, 1950-1994

Table 3.1. Number of Canada Geese Recoveries by Age at Banding, Banding Years, and Recovery Distance

\begin{tabular}{cccccc}
\hline & & \multicolumn{4}{c}{ Recovery Distance } \\
\cline { 3 - 6 } Years & Number & \multicolumn{2}{c}{ Adults } & \multicolumn{2}{c}{ Juveniles } \\
\cline { 3 - 6 } & of Years & Less than $80 \mathrm{~km}$ & More than $80 \mathrm{~km}$ & Less than $80 \mathrm{~km}$ & More than $80 \mathrm{~km}$ \\
\hline $1950-1959$ & 10 & 80 & 54 & 138 & 130 \\
$1960-1970$ & 10 & 75 & 25 & 156 & 95 \\
$1983-1994$ & 9 & 55 & 16 & 86 & 37 \\
\hline
\end{tabular}

Migrating birds tended to move either southward into California or to the northeast into southern Alberta and southwestern Saskatchewan. Hanson and Eberhardt (1971) speculated that migrating birds initially migrated to California and, on their return north, many appeared to continue on into Canada. Ball et al. (1981) analyzed the recovery pattern for more than 8,000 birds banded between 1950 and 1977 in Washington State. These results show a similar spatial distribution in recoveries, although they reported 
that a majority of the migrating geese headed northeast into southern Alberta and southwestern Saskatchewan. This northward migration was thought to be a molt migration. When geese molt, they lose both flight and tail feathers and are rendered flightless (Reed et al. 2003). Birds taking part in a molt migration are generally the nonbreeders or failed breeders. There is some controversy about whether the geese recovered in Canada represent a molt migration (i.e., nonbreeding birds) or breeding population (Ball et al. 1981). Both breeding and nonbreeding birds were recovered in Canada. However, younger birds (i.e., $1.5 \mathrm{yrs}$ ) represented a higher proportion of the total recoveries.

Overall, more than $60 \%$ of the birds are year-round residents. Similar results were reported by Culbertson et al. (1971) for Canada geese nesting on the Snake River. Hanson and Eberhardt (1971) determined that $75 \%$ of the Hanford Reach geese remained in the local area the first year after banding. Local recoveries were concentrated in the areas northeast of the Hanford Site and were highly dependent on where the birds were banded (Ball et al. 1981), indicating that the birds tend to move in family units.

The proportion of the Canada goose population staying local in the Columbia Basin has changed over the 50 years of study. In the 1950s, slightly more than half of the geese stayed all year, while in the 1980s those geese remaining locally increased to $73 \%$. Reasons for the shift are probably related to the increase in large-scale agriculture within the area, which provides a more stable food supply. Hanson and Eberhardt (1971) suggested that one of the reasons for the increasing population of geese nesting in the Hanford Reach was the proximity to agriculture and the lack of public access to the islands. While there is more agriculture, there is no longer protection from the public. However, the birds seem to have adapted to the presence of people and are abundant in grass and lawn areas such as those found in parks and at schools. 


\subsection{Surveillance of Contaminants in Canada Geese}

Canada geese and other waterfowl are one of several species of fish and wildlife and other abiotic media that have been used to monitor the fate and transport of contaminants associated with Hanford Site operations under long-standing environmental surveillance programs (DOE 2007). Historic operations at the Hanford Site resulted in the production of both radiological and nonradiological wastes, including metals. These wastes were placed in various disposal sites at the Hanford Site, including trenches, cribs, ditches, ponds, and underground tanks (Poston et al. 2001). Fly ash also was released into the atmosphere from coal-fired steam power plants associated with each reactor; these effluents contained trace metals and natural radionuclides (uranium and thorium decay series, carbon-14, potassium-40, and others) that may have deposited on the soil around the reactor areas.

In addition to waste associated with past Hanford Site operations, geese were exposed to fallout from nuclear weapons testing and metals generated from upriver mining and smelting activities that have been transported down the Columbia River and into the Hanford Reach (Johnson et al. 2005). Also, contaminants associated with past and present agricultural practices have contributed to the contaminant inventory at the Hanford Site (Yokel and Delistraty 2003). For example, arsenic is likely associated with historical applications of lead arsenate, a commonly used insecticide in fruit tree orchards. Studies examining the extent of arsenic contamination in pre-Hanford Site orchard soils near the 100 Area have shown elevated levels of arsenic in the soil compared to background levels (Yokel and Delistraty 2003).

Contaminants have been monitored in geese that inhabit the Columbia River and the Hanford Site since the 1960s as part of a much broader surveillance program. Extensive monitoring of waterfowl occurred during the early to mid 1960s when single-pass reactors were in maximum operating mode and much of the Hanford Reach was closed to the public (Keating and Harvey 2003). Single-pass reactors discharged a large amount of neutron activation products into the Columbia River, which subsequently were distributed throughout the river ecosystem (Becker 1990). Results from surveillance efforts have tracked this distribution in waterfowl and Canada geese; results were reported annually beginning in 1959. Since 1971, data on radionuclides found in waterfowl samples collected from the Hanford Reach have been stored in the Hanford Environmental Information System (HEIS) database. The HEIS data (1971-2007) were used for this evaluation of contaminant burdens in Canada geese.

Adult Canada geese graze on aquatic plants, grasses, and other upland and shoreline plants (Rickard and Sweany 1977) and have access to areas of the Hanford Site that contain radioactive or chemical contamination. Monitoring the level of contaminants in tissues of geese may help identify changes in environmental conditions over time and describe the extent and degree to which Hanford Site materials are present in the environment and the responses of biota to contaminant exposure. Geese exposed to Hanford Site contaminants might be harvested for food and may potentially contribute to offsite public exposure.

Most of the contaminant monitoring and analysis of wildlife on the Hanford Site has focused on radionuclides associated with reactor operations, fuel processing, or wastes generated during the historical production of plutonium onsite. Recent waste cleanup activities have expanded the monitoring focus to include possible heavy metal contamination. 
Objectives of this section are to review and evaluate radionuclide concentrations for 1971 through 2007 and trace metal concentrations for 2001 through 2007 found in Canada goose tissue and eggshell samples collected as part of Hanford Site monitoring and surveillance programs. A fundamental question regarding metals is whether or not geese residing along the Hanford Reach have accumulated higher concentrations of metals than those geese collected from reference areas away from the Hanford Site. A study conducted in 2001 also examined the relationship between trace metal levels in eggshells and hatching success. The remainder of this section discusses the methods used to collect and analyze these samples; the time frame and sampling sites for contaminant surveillance of Canada goose muscle, bone, and eggshells; and the radionuclide and trace metal concentrations in goose tissue. These concentrations are discussed in the context of dose estimates for radionuclides and a comparison to available toxicological benchmarks and biomarkers for metals.

\subsection{Methods}

This section describes the sample collection sites and the history of sampling Canada geese on the Hanford Site. The methods used to analyze radionuclides and metals are described, as are the statistical methods and models used to evaluate spatial differences in contaminant levels.

\subsubsection{Study Area and Years}

Geese were sampled from two main areas of the Hanford Site for contaminant monitoring. The first area encompassed the 100 Areas, including D Island at RK 607 (RM 377). A second collection area extended from the Hanford town site at RK 584 (RM 363) downstream to the 300 Area at RK 554 (RM 344). Reference samples were collected from a third area upstream of Priest Rapids Dam at RK 644 (RM 400) in 1999, 2001, 2003 and 2005. In 2007, five geese were obtained from the Moses Lake area as reference samples, which were tentatively identified as lesser Canada geese (B. c. parvipes). Sampling objectives of the monitoring efforts changed over time, and those changes are reflected in where geese were sampled, what tissues were collected, and which contaminants were identified for analysis.

From 1971 through 1989, geese were collected from specific locations in the Hanford Reach for gamma spectrometry of muscle samples. The locations included the six 100 Areas $(\mathrm{B} / \mathrm{C}, \mathrm{K}, \mathrm{N}, \mathrm{D}$ (including D Island), H, and F), White Bluffs, the Hanford town site, and Savage Island (Figure 4.1). Sampling of Canada geese resumed in 1994 for both gamma spectroscopy and strontium-90 analysis of muscle and bone tissue. In 1995, sampling was placed on an alternating year schedule; the last sample for this report was collected in 2007.

Beginning in 1991 and continuing on an intermittent basis, Canada goose eggshells were sampled and analyzed for strontium- 90 as part of the surveillance and ecological monitoring programs. Eggshells were collected in 1991-1993, 1995, 2001, and 2003. With the exception of the last two sampling events, all eggshells were collected from islands in the Hanford Reach. Eggshell samples were collected also in the 1980s for special studies (Rickard and Sweany 1977; Rickard and Price 1990). Sampling of eggshells for contaminants is a method that circumvents the sampling of live birds and, for some contaminants, is clearly an effective and nondestructive approach to contaminant surveillance. 


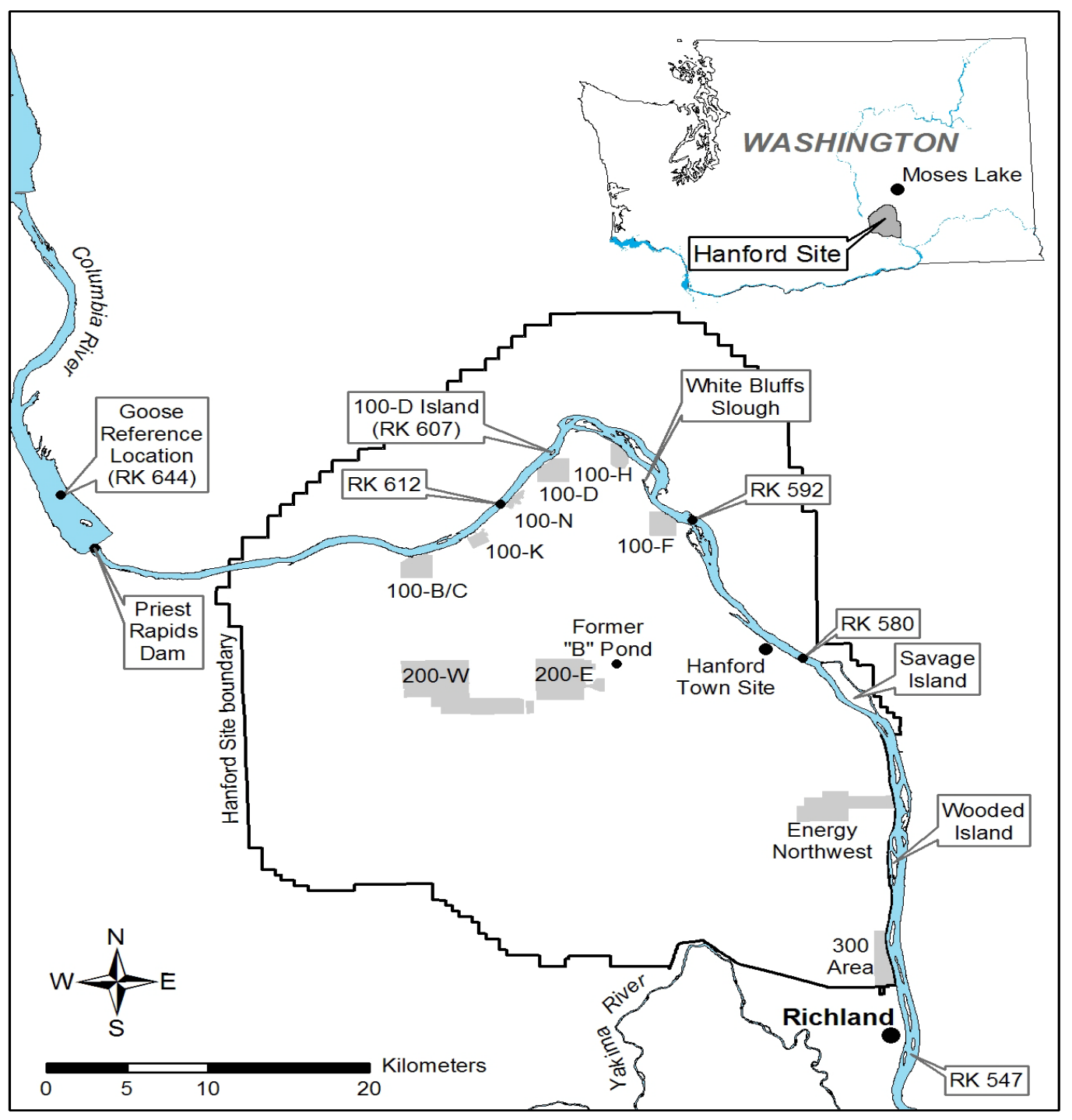

Figure 4.1. Canada Goose Collection Locations in the Hanford Reach of the Columbia River and at the Upstream Reference Location, 1971-2007

\subsubsection{Sample Collection}

A total of 218 adult and juvenile geese were collected along the Hanford Reach from 1971 to 2007 for contaminant analyses. In the early years, only goose muscle (breast) was analyzed for radionuclides. However, beginning in 1994, bone tissue also was analyzed for strontium-90. Beginning in 2001, liver samples also were taken for metals analyses from all geese sampled. Along the shoreline or on the islands near the 100 Areas, 151 geese were collected; 41 geese were collected downstream of the 100 Areas, in the region extending from the Hanford town site to the 300 Area (Figure 4.1). Eleven geese were collected at the Priest Rapids Dam pool reference location upstream of the Hanford Site in 1999 (radionuclide analyses only), 2001, 2003, and 2005. Five additional reference geese were collected from the Moses Lake area in December 2007. 
A total of 178 eggshell samples collected from 1985 through 2001 were analyzed for strontium-90, and 31 samples collected in 2001 were analyzed for metals. The eggshells were collected after hatching had occurred. In 2001, eggshells were collected from nests where either the hatch was $100 \%(N=21)$ or where some eggs had not hatched but at least one egg had hatched $(N=10)$. The objective of sorting the data based on hatching success was to see whether the results for metal concentrations in eggshells might be related to hatching success. In previous years, eggshell fragments were collected with no information on nest hatching success. Eggshells were collected from the reference location in the Priest Rapids Dam pool $(N=13)$, the ten upper islands adjacent to the 100 Area sampling locations $(N=31)$, and the lower islands $(N=134)$ located downstream of the Hanford town site to the city of Richland. Unhatched eggs, for the most part, were infertile. If the nest had been used in previous years, there was no absolute assurance that eggshell fragments collected in any one year were from eggs laid that year. However, nest material ordinarily is dispersed between breeding seasons, and the collection of eggshell fragments after the goslings have fledged usually ensures that the eggshell fragments were recent.

\subsubsection{Radionuclide Analysis}

This review covers the period 1971 through 2007, which includes the tail-end of the period when single-pass reactors were operating. Radionuclides associated with single-pass reactor discharges included phosphorus-32, cobalt-58, zinc-65, manganese-54, europium-152, and zirconium-niobium-95. These radionuclides, formed by neutron activation, were analyzed in samples of Canada goose muscle in the 1970s. With the exception of europium-152, the half-lives of the predominant activation products associated with single-pass reactor operations ranged from 14.3 to 312 days. The primary focus of our review is on gamma emitters (cobalt-60 and cesium-137) in muscle samples, and strontium-90 in bone and eggshell. These isotopes, in addition to having relatively long half-lives, are the most frequently measured radionuclides in wildlife samples.

All radionuclide analyses for goose samples (muscle and bone) were performed by Severn Trent Laboratories or its predecessor parent companies of U.S. Testing (1965-1990), International Technologies-Analytical Services (1990-1998), or Quanterra Environmental Services (1998-2000). Samples analyzed for gamma emitters were analyzed by gamma spectroscopy. In 1971 and 1972, analyses were performed with a sodium iodide crystal. Subsequent analyses were performed with a lithium-drifted germanium ( $\mathrm{Ge}[\mathrm{Li}])$ detector with a multichannel pulse-height analyzer. Analysis for strontium-90 in muscle, bone, and eggshell samples required a radiochemical methodology. Samples were ashed in a muffle furnace and dissolved in nitric acid. The dissolved ash was scavenged with barium nitrate, and the strontium was precipitated as a carbonate that was transferred to a stainless steel planchet and counted on a gas flow proportional counter. At least $10 \mathrm{~g}$ of sample media were needed to attain a detection limit of 0.005 picocuries per gram (pCi/g) wet weight (wt). In 2003, the detection limit was raised to $0.05 \mathrm{pCi} / \mathrm{g}$ wet $\mathrm{wt}$ to facilitate analysis and still provide an adequate margin of safety for dose-based standards.

Eggshell samples were submitted as essentially dry samples, and the results are reported as dry rather than wet weight. All other radionuclide analyses were reported on a wet weight basis. 


\subsubsection{Metal Analyses}

A number of metals (e.g., chromium, copper, lead, mercury, and uranium) have the potential to accumulate in certain fish and wildlife tissues and have been identified in the Hanford Site environment as potential contaminants of concern, particularly in areas of the Site where contaminated groundwater enters the Columbia River along the shoreline (Poston et al. 2003). Organisms can accumulate metals through incidental soil ingestion and water uptake and by eating food from both plant and animal sources that have been exposed to metals in the soil, air, and water.

Tissue samples were removed from geese, placed in pre-tared sample vials, frozen, and shipped to the analytical laboratory via overnight mail for processing and analysis. The frozen samples were freezedried and homogenized using a ball-mill prior to digestion according to Battelle SOP MSL-C-003, Percent Dry Weight and Homogenizing Dry Sediment, Soil and Tissue. Tissue samples were digested according to Battelle SOP MSL-I-024, Mixed Acid Tissue Digestion. An approximately 500-mg aliquot of each dried, homogeneous sample was combined with nitric and hydrochloric acids (aqua regia) in a Teflon vessel and heated in an oven at $130^{\circ} \mathrm{C}\left( \pm 10^{\circ} \mathrm{C}\right)$ for a minimum of eight hours. After heating and cooling, deionized water was added to the acid-digested tissue to achieve analysis volume, and the digestates were submitted for analysis.

The same process was used for the analysis of metals in eggshell fragments. The eggshells were cleaned with deionized water, and any dried membrane residue was removed prior to submitting the samples for analysis.

Soft tissue samples were collected in 2001, 2003, 2005, and 2007 for metals analysis. In 2001, samples included both kidney and liver. The 2001 samples were analyzed primarily with inductively coupled plasma (ICP) spectrometry analyses. However, the ICP sample preparation had high and variable recoveries due to faulty sample preparation, and the results were questionable. The mercury analysis used a separate preparation, and those results were acceptable and are summarized here.

For samples collected in 2003, digested samples were analyzed for barium, chromium, copper, and manganese using inductively coupled plasma optical emission spectroscopy (ICP-OES) according to Battelle SOP MSL-I-033, Determination of Elements in Aqueous and Digestate Samples by ICP-OES. This procedure is based on two methods modified and adapted for analysis of low-level samplesU.S. Environmental Protection Agency (EPA) Method 6010B, Inductively Coupled Plasma-Atomic Emission Spectrometry, and Method 200.7, Trace Elements in Water, Solids, and Biosolids by Inductively Coupled Plasma-Atomic Emission Spectrometry.

Inductively coupled plasma optical emission spectroscopy was also used to analyze for aluminum and chromium in samples collected during 2005. All other metals reported for 2003 and 2005 samples were analyzed by using inductively coupled plasma mass spectrometry (ICP-MS) according to Battelle SOP MSL-I-022, Determination of Elements in Aqueous and Digestate Samples by ICP/MS. This procedure is based on two methods modified and adapted for analysis of low-level solid sample digestates-EPA Method 1638, Determination of Trace Elements in Ambient Waters by Inductively Coupled Plasma-Mass Spectrometry, and EPA Method 200.8, Determination of Trace Elements in Waters and Wastes by Inductively Coupled Plasma - Mass Spectrometry. 
All digested samples were analyzed for mercury by cold vapor atomic absorption spectroscopy (CVAA) according to Battelle SOP MSL-I-016, Total Mercury in Tissues and Sediments by Cold Vapor Atomic Absorption, which is based on EPA Method 245.6, Determination of Mercury in Tissue by Cold Vapor Atomic Absorption Spectrometry.

\subsubsection{Grouping of Metals by Detection Limits}

For many of the radionuclides and metals, concentrations in tissues were below levels that can be detected by the analytical laboratory. In those cases, the achieved laboratory detection limit was used as a conservative estimate of the minimum detectable amount of the contaminant for metals analysis (Table 4.1). Because of slight differences in methods and, to some degree, the actual concentrations of metals found in goose liver, metals were partitioned into two groups based on how frequently they were detected in liver samples. Metals in Group I were aluminum, arsenic, cadmium, chromium, copper, lead, manganese, mercury, thallium, selenium, and zinc; these metals were detected in nearly all if not all samples collected in 2003, 2005, and 2007. Metals from a second subset (Group II), antimony, beryllium, barium, nickel, silver, thorium and uranium, were detected less frequently and, as a result, were not subjected to the statistical analyses performed on the first group.

\subsubsection{Statistical Methods}

Descriptive statistics were generated for metals data in liver samples. Data were screened to remove those metals for which the majority or all of the results were below detection or analyses were missing (Group II metals; Appendix B). For Group I metals, the data were log-transformed to reduce the variability and analyzed using analysis of variance (ANOVA). A one-way ANOVA was conducted based on general sampling areas (onsite and offsite). Differences between specific sampling locations were also analyzed by ANOVA, and Scheffé's post hoc tests for multiple comparisons were conducted with an alpha level of 0.05 . Metal concentrations reported as less than detection were analyzed at the reported detection level for the metal.

\subsubsection{Comparisons to Benchmarks}

To gain a better understanding of the potential risk associated with hepatic metal concentrations, we reviewed toxicological benchmarks for waterfowl and the range of concentrations of metals detected in other populations of waterfowl in North America. We recognize that there are likely species differences in both the tolerance and metabolism of metals. The amount of toxicity information available for geese was limited, and we restricted our comparisons to waterfowl (primarily ducks) to minimize the variability and uncertainty for these comparisons. In addition to the open literature, toxicity benchmarks have been compiled in the Environmental Residue-Effects Database (ERED; U.S. Army Corps of Engineers/ U.S. Environmental Protection Agency [USACE/EPA] 2005). The USGS Contaminants Exposure and Effects Database (Rattner et al. 2006) also was reviewed to collect additional information on benchmarks and the levels of metals reported in waterfowl collected in North America. 
Table 4.1. Laboratory-Achieved Detection Limits ( $\mu \mathrm{g} / \mathrm{g}$ dry wt) for Group I and II Metals

\begin{tabular}{|c|c|c|c|c|c|c|c|c|c|c|c|c|c|c|c|}
\hline \multirow[b]{2}{*}{ Metal } & \multicolumn{3}{|c|}{2003 - Batch 1} & \multicolumn{3}{|c|}{$2003-$ Batch 2} & \multicolumn{3}{|c|}{2005 - Batch 1} & \multicolumn{3}{|c|}{2007 - Batch 1} & \multicolumn{3}{|c|}{$2007-$ Batch 2} \\
\hline & $\mathrm{LADL}^{(\mathrm{a})}$ & $N^{(\mathrm{b})}$ & $N>\mathrm{DL}^{(\mathrm{c})}$ & LADL & $N$ & $N>\mathrm{DL}$ & $\overline{\text { LADL }}$ & $N$ & $N>\mathrm{DL}$ & LADL & $N$ & $N>\mathrm{DL}$ & LADL & $N$ & $N>\mathrm{DL}$ \\
\hline \multicolumn{16}{|c|}{ Group I } \\
\hline Aluminum & 0.109 & 7 & 7 & 0.109 & 6 & 6 & 1 & 17 & 17 & 0.5 & 10 & 10 & 0.5 & 5 & 5 \\
\hline Arsenic & 0.2 & 7 & 6 & 0.2 & 6 & 0 & 0.07 & 17 & 15 & 0.1 & 10 & 10 & 0.1 & 5 & 0 \\
\hline Cadmium & 0.025 & 7 & 7 & 0.025 & 6 & 6 & 0.008 & 17 & 17 & 0.002 & 10 & 10 & 0.002 & 5 & 5 \\
\hline Chromium & 0.1 & 7 & 7 & 0.015 & 6 & 6 & 0.1 & 17 & 17 & 0.1 & 10 & 10 & 0.042 & 5 & 5 \\
\hline Copper & 0.04 & 7 & 7 & 0.08 & 6 & 6 & 0.05 & 17 & 17 & 0.09 & 10 & 10 & 0.08 & 5 & 5 \\
\hline Lead & 0.034 & 7 & 5 & 0.034 & 6 & 6 & 0.03 & 17 & 15 & 0.003 & 10 & 10 & 0.003 & 5 & 5 \\
\hline Manganese & 0.009 & 7 & 7 & 0.034 & 6 & 6 & 0.033 & 17 & 17 & 0.07 & 10 & 10 & 0.02 & 5 & 5 \\
\hline Mercury & 0.005 & 7 & 7 & 0.005 & 6 & 6 & 0.002 & 17 & 17 & 0.005 & 10 & 10 & 0.005 & 5 & 5 \\
\hline Selenium & 0.5 & 7 & 7 & 0.05 & 6 & 6 & 0.1 & 17 & 17 & 0.2 & 10 & 10 & 0.2 & 5 & 5 \\
\hline Thallium & 0.018 & 7 & 7 & 0.018 & 6 & 6 & 0.004 & 17 & 11 & 0.003 & 10 & 10 & 0.01 & 5 & 3 \\
\hline Zinc & 0.94 & 7 & 7 & 0.94 & 6 & 6 & 0.7 & 17 & 17 & 0.1 & 10 & 10 & 0.1 & 5 & 5 \\
\hline \multicolumn{16}{|c|}{ Group II } \\
\hline Antimony & 0.019 & 7 & 5 & 0.019 & 6 & 0 & 0.01 & 17 & 5 & 0.02 & 10 & 0 & 0.02 & 5 & 0 \\
\hline Beryllium & 0.019 & 7 & 0 & 0.019 & 6 & 5 & 0.007 & 17 & 1 & 0.02 & 10 & 0 & 0.01 & 5 & 0 \\
\hline Barium & 0.03 & 7 & 7 & $\mathrm{NA}^{(\mathrm{d})}$ & & & NA & & & NA & & & NA & & \\
\hline Nickel & 0.045 & 7 & 2 & 0.045 & 6 & 2 & 0.05 & 17 & 2 & 0.04 & 10 & 2 & 0.04 & 5 & 0 \\
\hline Silver & 0.045 & 7 & 1 & 0.045 & 6 & 1 & 0.003 & 17 & 17 & 0.01 & 10 & 4 & 0.01 & 5 & 3 \\
\hline Thorium & 0.021 & 7 & 1 & 0.021 & 6 & 0 & 0.01 & 17 & 10 & 0.003 & 10 & 8 & 0.01 & 5 & 1 \\
\hline Uranium & 0.031 & 7 & 0 & 0.031 & 6 & 0 & 0.002 & 17 & 17 & 0.002 & 10 & 4 & 0.002 & 5 & 0 \\
\hline
\end{tabular}

(a) $\mathrm{LADL}=$ laboratory achieved detection limit.

(b) $N=$ number of samples.

(c) $N>\mathrm{DL}=$ number of samples greater than the detection limit.

(d) NA = not analyzed. 


\subsection{Results}

Results are organized into two sections_-radionuclides and metals.

\subsubsection{Radionuclides}

Radionuclides discharged to the Columbia River were either neutron activation products or, in some cases, fission products that were released following fuel element failures. The activation products are associated with single-pass reactor operations. The more persistent radionuclides found in Canada geese are fission products associated with historic weapons testing fallout and 100-N reactor operations. Because goose samples were collected over a longer period of time, the data for radionuclides allow for an assessment of trends.

\subsubsection{Activation Products}

With the exception of europium-152 and cobalt-60, the half-lives of the predominant activation products associated with single-pass reactor operations for Canada goose muscle were less than a year, ranging from 14.3 to 312 days (Table 4.2). Most of the values reported for manganese-54, cobalt-58, cobalt-60, zinc-65, and zirconium-niobium-95 were less than detection. Within a few years of the cessation of single-pass reactor operations, these radionuclides had essentially decayed to stable decay products (Cushing et al. 1980). Europium-152 has not been detected since 1980 in goose samples and is strongly associated with river sediment samples (Patton and Dirkes 2007). Cobalt-60, observed only infrequently in goose samples, is discussed in more detail below.

Table 4.2. Median and Maximum Radionuclide Concentrations (pCi/g wet wt) Reported in Canada Goose Muscle Samples After Cessation of Single-Pass Reactor Operations in 1971

\begin{tabular}{|c|c|c|c|c|c|}
\hline Radionuclide & Half-Life $^{(a)}$ & Median & Maximum & $\begin{array}{l}\text { Samples Greater } \\
\text { Than Detection/ } \\
\text { Total Samples }\end{array}$ & Years \\
\hline Phosphorus-32 & 14.3 days & 0.52 & 1.19 & $9 / 10$ & 1971 \\
\hline Cobalt-58 & 70.8 days & 0.28 & 0.57 & $1 / 2$ & $1971-1972$ \\
\hline Cobalt-60 & 5.27 years & 0.02 & 0.17 & $26 / 165$ & 1972-2005 \\
\hline Zinc-65 & 244.2 days & 0.01 & 1.32 & $43 / 107$ & 1971-1976 \\
\hline Manganese-54 & 312.0 days & $\mathrm{NA}^{(\mathrm{b})}$ & 0.02 & $0 / 1$ & 1977 \\
\hline Europium-152 & 13.5 years & 3.07 & 4.25 & $5 / 5$ & 1971,1980 \\
\hline Zirconium-niobium-95 & 65 days -35 days ${ }^{(\mathrm{c})}$ & 0.01 & 0.02 & $0 / 6$ & 1977,1994 \\
\hline \multicolumn{6}{|c|}{$\begin{array}{l}\text { (a) Half-lives taken from Unterweger et al. (2006) and Shlein (1992). } \\
\text { (b) NA - not applicable. } \\
\text { (c) The two values (days) reflect the half-lives for zirconium-95 and niobium-95, respectively. }\end{array}$} \\
\hline
\end{tabular}

\section{Cobalt-60}

Measurable concentrations of cobalt- 60 were found infrequently in Canada goose muscle in the early 1970s. Cobalt-60 concentrations above the detection limit (nominally $0.02 \mathrm{pCi} / \mathrm{g}$ wet wt) were not detected in tissue samples after 1976 (Figure 4.2). Concentrations measured in the early 1970s may 
reflect discharges from the single-pass reactors. The three values above $0.02 \mathrm{pCi} / \mathrm{g}$ wet weight between 1997 and 2003 were recorded as below detection because quality assurance procedures determined there were high analytical uncertainties for that particular analysis.

\subsubsection{Fission Products}

The fission products cesium-137 and strontium-90 are the predominant radionuclides found in Canada goose samples in recent years.

\section{Cesium-137}

Since the 1980s, concentrations of cesium-137 in Canada goose muscle have fluctuated around the level of detection ( $~ 0.015$ to $0.02 \mathrm{pCi} / \mathrm{g}$ wet wt; Figure 4.3$)$. The maximum concentration in goose muscle collected from the Columbia River $(3.7 \mathrm{pCi} / \mathrm{g}$ ) was measured in 1976 . Concentrations of cesium-137 in Canada goose muscle have historically fallen below concentrations observed in onsite resident waterfowl such as mallard ducks and are similar to levels expected from historic weapons fallout. Because the recent concentrations were below detection, no statistical analyses were conducted on cesium-137 in Canada goose muscle.

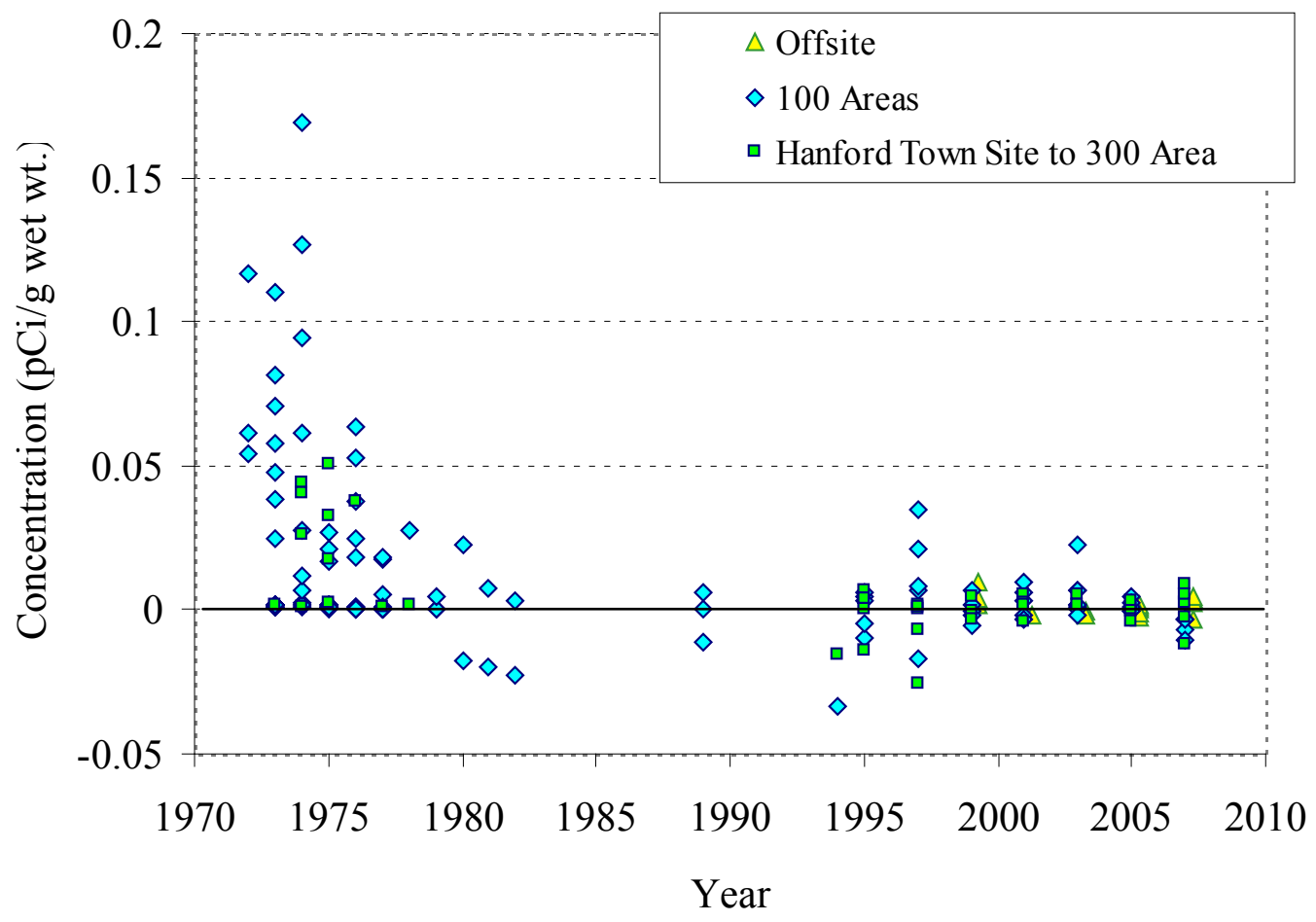

Figure 4.2. Cobalt-60 in Canada Goose Muscle, 1971-2007 


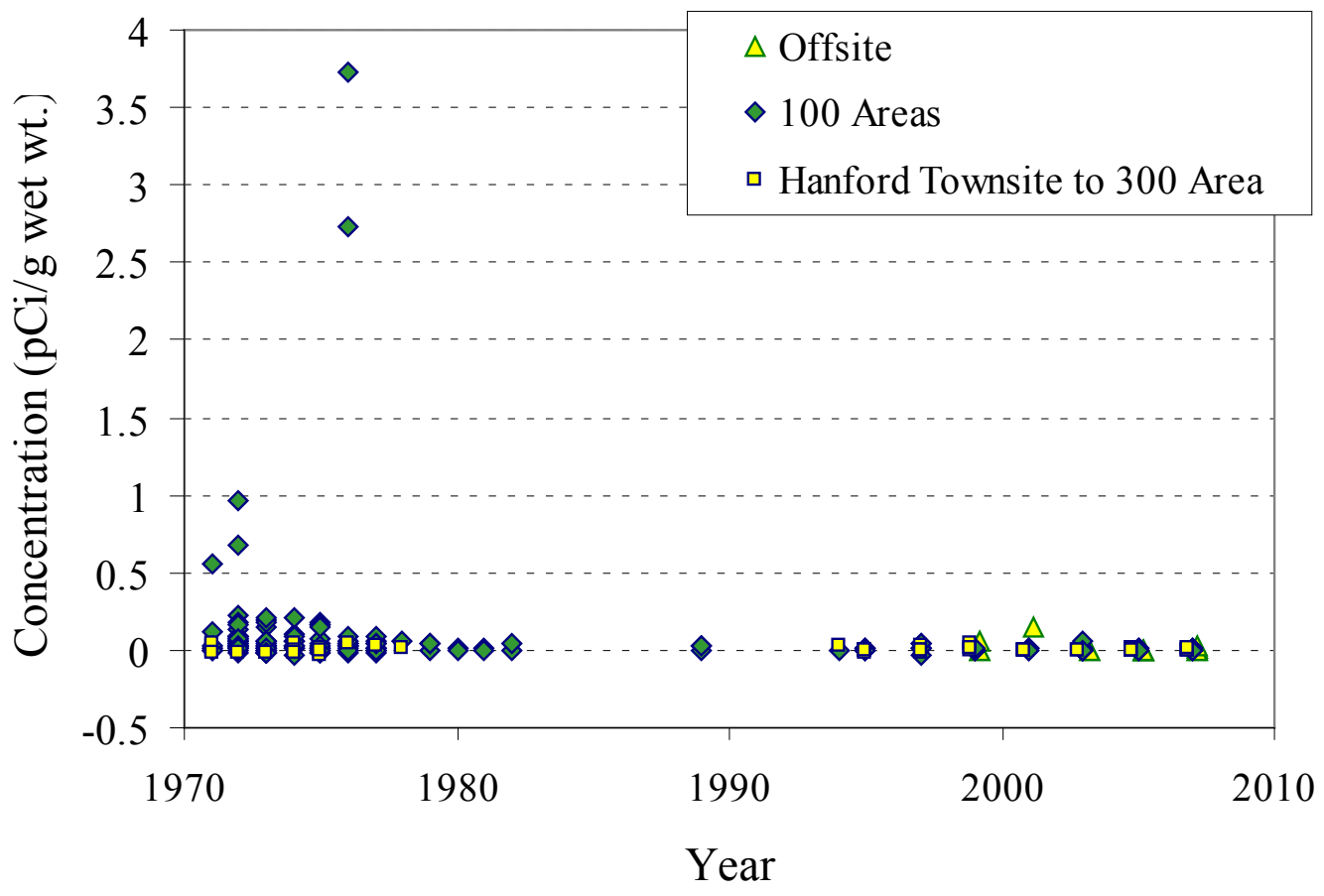

Figure 4.3. Cesium-137 in Canada Goose Muscle, 1971-2007

\section{Strontium-90}

Strontium-90 was analyzed in muscle, bone, and eggshell samples of Canada geese. Concentrations of strontium-90 in goose muscle were analyzed in 1972 and again in 1994, 1995, and 1997. Only 2 of the 14 muscle sample concentrations from 1972 were less than detection (essentially " 0 " pCi/g); however, no quantification of analytical error was provided, and most of the 1972 results (13 of 14) were reported at concentrations that fall below the contractual minimum detectable concentration (MDC) of the 1990s ( $0.005 \mathrm{pCi} / \mathrm{g})$. In muscle samples collected from 1994 through 1997, 17 of 22 concentrations fell below the detection level of $0.005 \mathrm{pCi} / \mathrm{g}$ wet wt. The maximum value reported was $0.098( \pm 0.060) \mathrm{pCi} / \mathrm{g}$ wet wt from a sample collected from the Hanford town site in 1997.

Strontium-90 was detected frequently in goose bone samples collected from 1994 through 2005, with concentrations onsite decreasing after 1995 (Figure 4.4). The maximum concentrations of strontium-90 were highest in samples collected from the 100 Areas in 1995 (Figure 4.5). A Kruskal-Wallis nonparametric analysis of the data by location indicated no significant difference $(P=0.25)$ in strontium concentration in bone between locations for all data collected between 1994 and 2005. No adjustments were made in the analysis for radiological decay over the 12 years of sample collection.

Strontium-90 concentrations were analyzed in eggshells collected from Canada goose nests. Analytical results (Figure 4.6) show strontium-90 levels have decreased since the late 1980s when concentrations were generally greater than 1 pCi/g dry wt. In 1995 and 2001, strontium-90 concentrations in eggshells collected from islands in the Hanford Reach were similar to those in eggshells collected at the reference location upstream of the Hanford Site from an island in the Priest Rapids Dam pool (see Figure 4.1). 


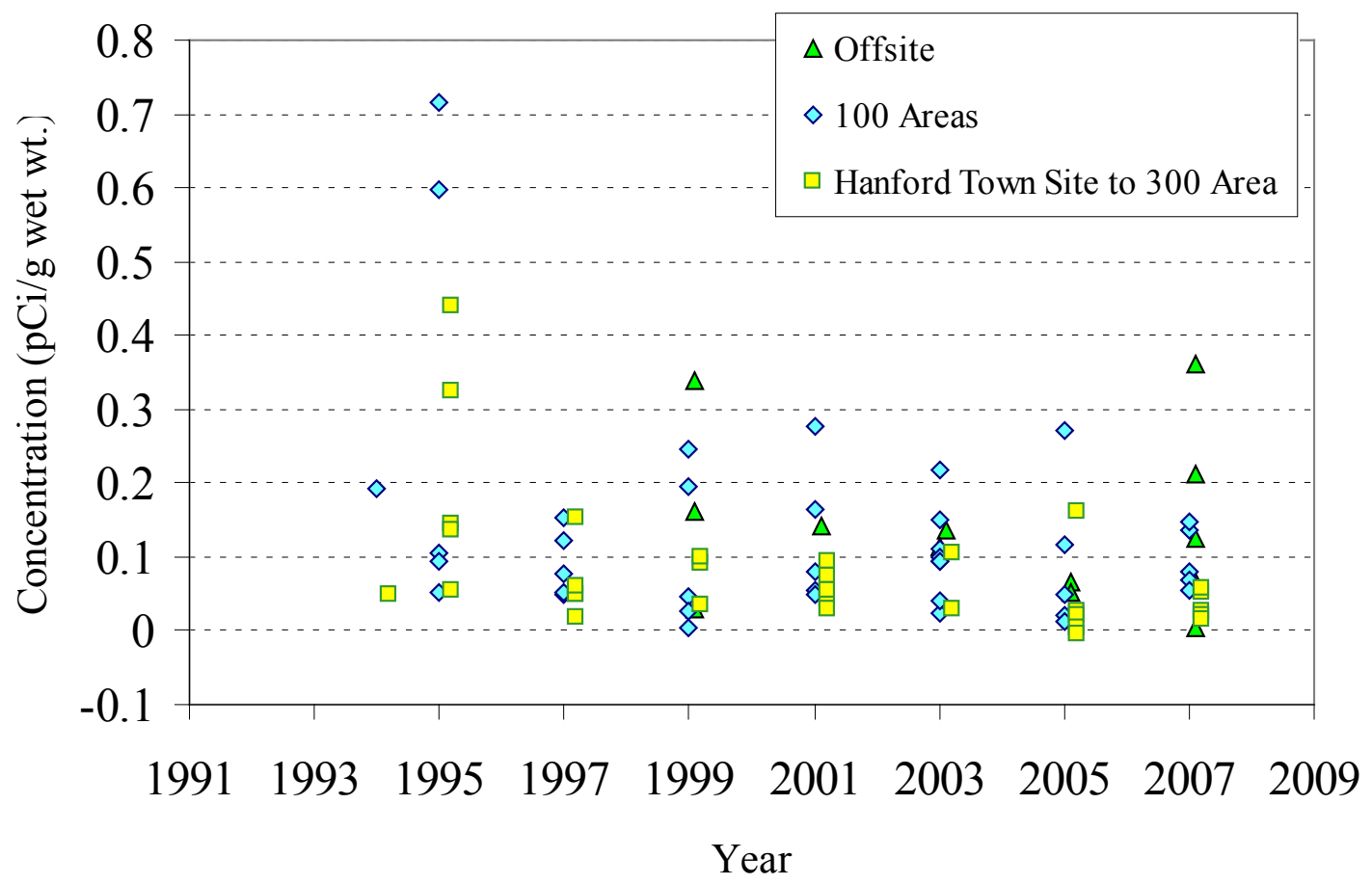

Figure 4.4. Strontium-90 in Canada Goose Bone, 1994-2007

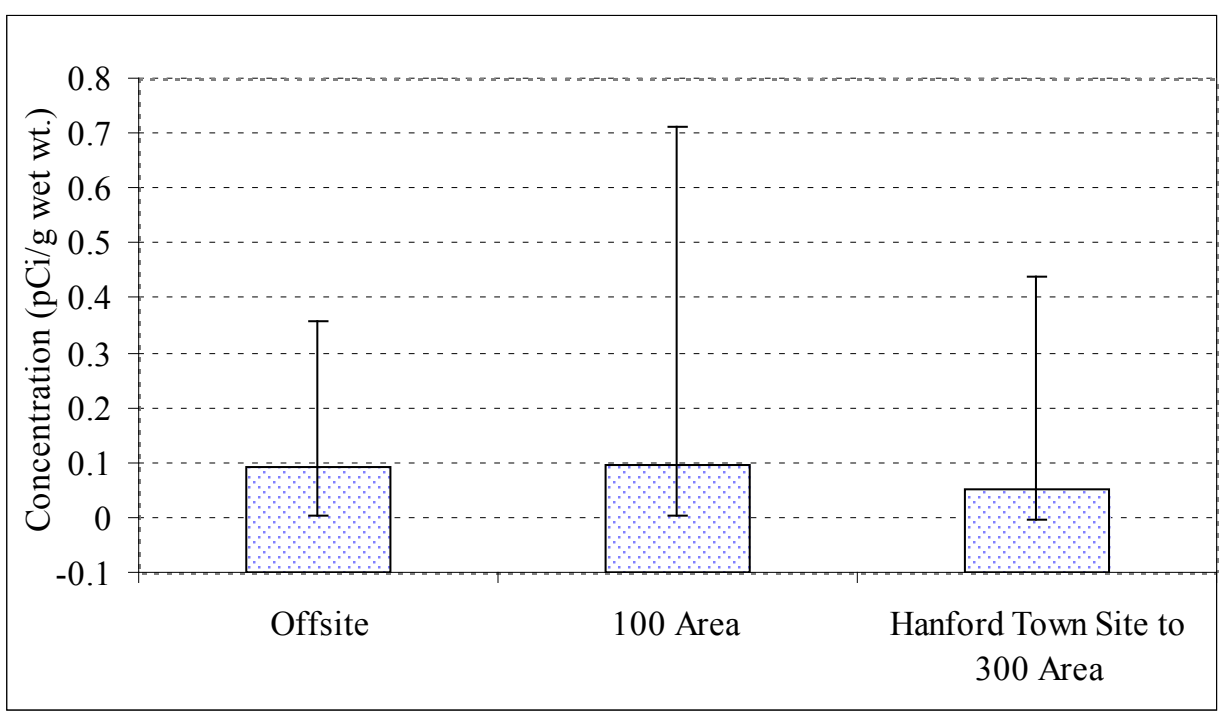

Figure 4.5. Maximum, Median, and Minimum Concentrations of Strontium- 90 in Canada Goose Bone by Sampling Area, 1994-2007 


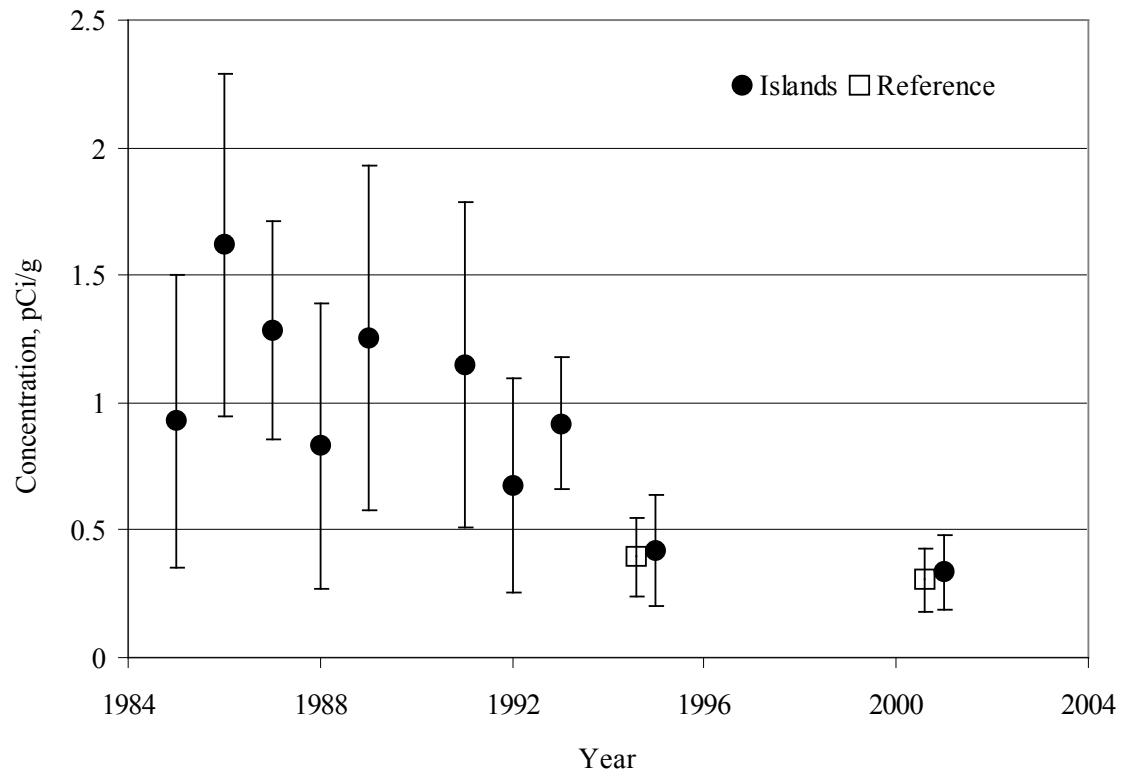

Figure 4.6. Mean Strontium-90 Concentration (pCi/g dry wt \pm 1.0 Standard Deviation $[\mathrm{SD}]$ ) in Canada Goose Eggshells from Islands in the Hanford Reach, Columbia River, 1985-2001. Reference samples were collected from the Priest Rapids Reservoir upstream of the Hanford Site.

\subsubsection{Metals}

Metals analyses were performed on goose liver samples collected in 2001, 2003, 2005, and 2007. Metals analysis was performed also on eggshells and kidney tissue collected in 2001. Due to poor analytical recoveries in liver and kidney samples collected in 2001 (see Section 4.1.4), only results for mercury concentrations were used in this report.

\subsubsection{Metals Concentrations in Goose Liver}

The Group I metals (aluminum, arsenic, cadmium, chromium, copper, lead, manganese, mercury, selenium, thallium, and zinc) were evaluated statistically for differences between sampling areas and for general descriptive parameters. Only basic descriptive statistics were calculated for the Group II metals (antimony, beryllium, barium, nickel, silver, thorium, and uranium). Information collected for the Group II metals is provided in Appendixes A and B.

Metal concentrations in Canada geese liver were quite variable, and initial inspection of the data does not indicate any obvious differences between metal concentrations in Canada geese collected onsite in comparison to those collected at reference locations at the Priest Rapids pool and near Moses Lake (Figure 4.7). A complete compilation of basic descriptive statistics for Group I metals, including sampling year and sampling location, may be found in Appendix A, Table A.2). These descriptive statistics provide basic information on the distribution of the metals data. To statistically analyze the data, the metal concentrations first were log-transformed because the distribution of environmental data is generally skewed. The log-transformed data then were analyzed by ANOVA. 


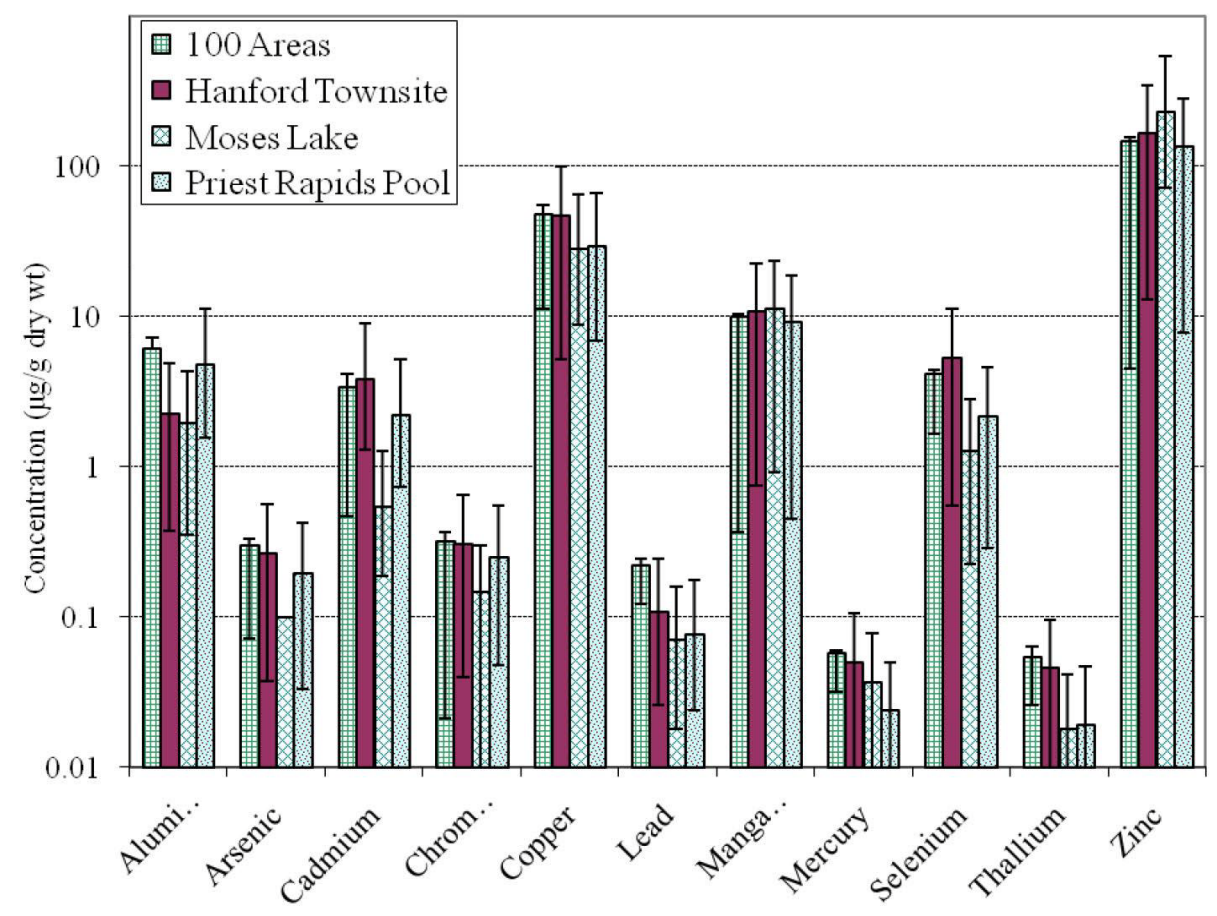

Figure 4.7. Mean ( $\pm 1 \mathrm{SE})$ of Group I Metal Concentrations in Canada Goose Liver $(\mu \mathrm{g} / \mathrm{g}$ dry wt)

Two analyses were conducted. The first test compared metal concentrations from Canada geese collected on the Hanford Site to metals concentrations found in birds collected offsite. Onsite included the 100 Areas and Hanford town site to the 300 Area, and offsite included Priest Rapids pool and Moses Lake. Of the 11 Group I metals, there was no apparent difference between the onsite and offsite data for aluminum, cadmium, manganese, and zinc (Table 4.3). Differences were significant $(P<0.05)$ for arsenic, chromium, copper, lead, mercury, selenium, and thallium. For these seven metals, the mean hepatic liver concentrations from geese collected onsite exceeded those collected offsite.

The second analysis looked for differences between sampling locations to determine if there were statistically significant differences (Table 4.3). The ANOVA indicated that statistically significant differences were detected for six of the seven metals identified in the onsite-offsite analysis; only the analysis of lead was not significant for individual locations. Scheffé's multiple comparison test was used to compare the six possible combinations of location pairs (Table 4.3). For all 11 Group I metals, there was no statistically significant difference between the two onsite locations (100 Areas and Hanford town site to the 300 Area) or between the two offsite areas (Priest Rapids pool and Moses Lake). In all cases where statistically significant differences were detected between sampling locations, the log-transformed mean concentrations in livers collected from the on site location exceed the log-transformed mean concentration at the offsite location. Interestingly, while the ANOVA for locations for copper was significant $(P=0.0382)$, none of the multiple comparison tests was significant.

Collectively, the statistical analysis of the liver metal data indicates elevated concentrations of metals in goose liver collected from Canada geese along the Hanford Reach shoreline compared to those collected at either the upstream reference location at Priest Rapids pool or at the Moses Lake location. Selenium and thallium were consistently higher in Hanford Reach geese compared to both the Priest Rapids pool geese and the Moses Lake geese. Hepatic concentrations of arsenic and chromium in Canada 
Table 4.3. ANOVA Based on Onsite Versus Offsite and Specific Sample Location of Hepatic Metal Concentrations in Canada Geese, 2003-2007

\begin{tabular}{|c|c|c|c|c|c|c|c|c|c|}
\hline \multirow[b]{4}{*}{ Metal } & & & \multirow[b]{4}{*}{$\begin{array}{c}\text { ANOVA } \\
(\text { Significance; } P \text { ) } \\
\end{array}$} & \multicolumn{6}{|c|}{ Specific Locations } \\
\hline & & & & \multicolumn{6}{|c|}{ Scheffé's Post Hoc Comparison (Significance; $P)^{(\mathrm{a})}$} \\
\hline & \multicolumn{2}{|c|}{ Onsite vs. Offsite } & & \multirow[b]{2}{*}{$\begin{array}{c}100 \text { Areas } \\
\text { vs. Hanford } \\
\text { Town Site }\end{array}$} & \multirow[b]{2}{*}{$\begin{array}{c}100 \text { Areas } \\
\text { vs. Moses } \\
\text { Lake }\end{array}$} & \multirow{2}{*}{$\begin{array}{c}100 \text { Areas } \\
\text { vs. Priest } \\
\text { Rapids } \\
\text { Pool }\end{array}$} & \multirow{2}{*}{$\begin{array}{l}\text { Hanford } \\
\text { Town Site } \\
\text { vs. Moses } \\
\text { Lake }\end{array}$} & \multirow{2}{*}{$\begin{array}{c}\text { Hanford } \\
\text { Town Site } \\
\text { vs. Priest } \\
\text { Rapids Pool }\end{array}$} & \multirow[b]{2}{*}{$\begin{array}{c}\text { Moses Lake } \\
\text { vs. Priest } \\
\text { Rapids Pool }\end{array}$} \\
\hline & $\begin{array}{c}\text { ANOVA } \\
(\text { Significance; } P)^{(\mathrm{a})}\end{array}$ & $\begin{array}{c}\text { Onsite vs. } \\
\text { Offsite } \\
(<, \approx,>)^{(b)}\end{array}$ & & & & & & & \\
\hline Aluminum & 0.7217 & $\approx$ & 0.2002 & 0.5317 & 0.6664 & 0.9352 & 0.9991 & 0.3793 & 0.4850 \\
\hline Arsenic & 0.0014 & $>$ & 0.0019 & 0.8870 & 0.0029 & 0.3466 & 0.0202 & 0.7496 & 0.2288 \\
\hline Cadmium & 0.0945 & $\approx$ & 0.0841 & $>0.9999$ & 0.1067 & 0.9960 & 0.1385 & 0.9972 & 0.2700 \\
\hline Chromium & 0.0011 & $>$ & 0.0019 & 0.9809 & 0.0034 & 0.3975 & 0.0121 & 0.6406 & 0.2185 \\
\hline Copper & 0.0038 & $>$ & 0.0382 & 0.9869 & 0.2138 & 0.2868 & 0.1657 & 0.2221 & 0.9873 \\
\hline Lead & 0.0482 & $>$ & 0.1419 & 0.6497 & 0.3859 & 0.2888 & 0.8951 & 0.8712 & $>0.9999$ \\
\hline Manganese & 0.9687 & $\approx$ & 0.3953 & 0.7252 & 0.6976 & 0.9872 & 0.9901 & 0.6737 & 0.6337 \\
\hline Mercury & 0.0006 & $>$ & 0.0025 & 0.9824 & 0.5190 & 0.0043 & 0.7221 & 0.0181 & 0.4276 \\
\hline Selenium & $<0.0001$ & $>$ & $<0.0001$ & 0.4172 & $<0.0001$ & 0.0010 & $<0.0001$ & $<0.0001$ & 0.0731 \\
\hline Thallium & $<0.0001$ & $>$ & $<0.0001$ & 0.9561 & 0.0043 & $<0.0001$ & 0.0193 & $<0.0001$ & 0.5491 \\
\hline Zinc & 0.7076 & $\approx$ & 0.0770 & 0.7944 & 0.1847 & 0.9150 & 0.5685 & 0.5480 & 0.1205 \\
\hline
\end{tabular}

(a) Values $<0.05$ are significant.

(b) < indicates less than; $\approx$ indicates no difference; $>$ indicates greater than. 
metals in geese were higher in Hanford Reach birds than those collected at Moses Lake but not at the Priest Rapids pool area. Conversely, hepatic mercury concentrations were higher in Hanford Reach geese compared to Priest Rapids pool geese but not when compared to Moses Lake geese.

\subsubsection{Mercury in Liver and Kidney Samples, 2001}

Median mercury concentrations in goose kidney were slightly higher than median concentrations in goose liver (Appendix A, Table A.1). The median concentrations in liver collected in 2001 were similar to the median concentrations observed in samples collected in 2003, 2005, and 2007 (Appendix A, Table A.2). Maximum values for mercury in liver samples in 2001 ranged from 0.062 to $0.104 \mu \mathrm{g} / \mathrm{g}$ dry wt. These liver concentrations were lower than the maximum liver concentration $(0.157 \mu \mathrm{g} / \mathrm{g}$ dry wt $)$ observed in 2003 from the 100 Areas.

\subsubsection{Goose Eggshells}

Canada goose eggshells were collected in 2001 and analyzed for metals. Results were blankcorrected (i.e., the analytical blank concentration, if detected in the blank, was subtracted to produce the reported value) and are reported on a dry weight basis. Hatch rates were evaluated for the nests where the eggshells were collected. Hatching was either complete (all eggs hatched) or incomplete (at least one egg did not hatch). For nests with incomplete hatch, the mean percentage hatch rate was $72 \%$ and ranged from $23 \%$ to $84 \%$. All the nests with incomplete hatch rates were found in the lower part of the Hanford Reach between Wooded Island and the 300 Area (Figure 4.1).

Sixteen metals were analyzed in Canada goose eggshells. Nickel results were not used because of a systematic analytical interference from calcium. For the remaining metals, concentrations of arsenic, beryllium, silver, mercury, selenium, uranium, and antimony were generally below the detection limits. Comparison of metal concentrations in eggshells from nests with $100 \%$ hatch with eggshells from nests with unhatched eggs found a statistically significant difference $(P<0.05)$ for manganese and zinc. Manganese was higher in eggshells from nests with $100 \%$ hatch, while zinc was higher in eggshells with less than 100\% hatch (Table 4.4). No research was found linking manganese or zinc to hatching success in geese; however there is ample research for fowl and some other species of birds (Cooper 2001; Holthem and Powell 2000; Jamieson and Ryan 1999; Wiemeyer 2005). Studies examining hatching success in other species of birds exposed to manganese and zinc indicate that dietary deficiency of these two trace metals can impact hatchability of eggs. No apparent relationship was found between the concentration of the more toxic metals (i.e., lead, mercury, cadmium, arsenic, chromium) and hatching success. Chromium did not appear to be elevated in eggshells, nor was hatching success lower on the upper islands where exposure to chromium is potentially greater due to its presence in groundwater seepage along the 100 Areas shoreline (Hope and Petersen 1996). Concentrations of metals in eggshells collected from the reference location generally were similar to the levels in eggshells collected from the upper and lower parts of the Hanford Reach. 
Table 4.4. Metal Concentrations ( $\mu \mathrm{g} / \mathrm{g}$ dry wt) in Eggshells from Nests with Either $100 \%$ Hatch or Less Than 100\% Hatch (average $72 \%$ ) in 2006

\begin{tabular}{|c|c|c|c|c|c|c|c|c|c|c|}
\hline \multirow[b]{2}{*}{ Metal } & \multicolumn{4}{|c|}{$\begin{array}{l}\text { Hatched Eggs }(100 \% ; N=21) \\
\text { Islands } 1,5,10,15,18,19, \mathrm{PRP}^{(\mathrm{a})}\end{array}$} & \multicolumn{4}{|c|}{$\begin{array}{c}\text { Unhatched Eggs }(72 \% ; N=10) \\
\text { Islands } 17,18,19,20\end{array}$} & \multicolumn{2}{|c|}{$\begin{array}{c}\text { Reference Site }^{(\mathrm{a})} \\
(N=3)\end{array}$} \\
\hline & Mean & $2 \mathrm{SE}^{(\mathrm{b})}$ & $\begin{array}{l}\text { Maxi- } \\
\text { mum }\end{array}$ & $\begin{array}{c}\text { Number } \\
\text { Above } \\
\text { Detection }\end{array}$ & Mean & $2 \mathrm{SE}$ & $\begin{array}{c}\text { Maxi- } \\
\text { mum }\end{array}$ & $\begin{array}{c}\text { Number } \\
\text { Above } \\
\text { Detection }\end{array}$ & Mean & $\begin{array}{c}\text { Number } \\
\text { Above } \\
\text { Detection }\end{array}$ \\
\hline Arsenic & $<\operatorname{Det}^{(\mathrm{c})}$ & & & 0 of 21 & $<$ Det & & & 0 of 10 & $<$ Det & 0 of 3 \\
\hline Silver & $<$ Det & & & 0 of 21 & $<$ Det & & & 0 of 10 & $<$ Det & 0 of 3 \\
\hline Beryllium & $<$ Det & & & 0 of 21 & 0.04 & & 0.06 & 1 of 10 & $<$ Det & 0 of 3 \\
\hline Uranium & 0.010 & & 0.013 & 1 of 21 & $<$ Det & & & 0 of 10 & $<$ Det & 0 of 3 \\
\hline Selenium & 0.20 & & 0.26 & 1 of 21 & 0.21 & & 0.26 & 1 of 10 & $<$ Det & 0 of 3 \\
\hline Mercury & 0.001 & & 0.002 & 1 of 21 & 0.002 & 0.002 & 0.009 & 2 of 10 & 0.001 & 1 of 3 \\
\hline Antimony & 0.010 & 0.001 & 0.015 & 2 of 21 & 0.010 & 0.001 & 0.013 & 2 of 10 & 0.012 & 1 of 3 \\
\hline Chromium & 0.15 & 0.03 & 0.43 & 16 of 21 & 0.12 & 0.01 & 0.15 & 8 of 10 & 0.11 & 2 of 3 \\
\hline Lead & 0.08 & 0.03 & 0.35 & 20 of 21 & 0.12 & 0.11 & 0.46 & 9 of 10 & 0.14 & 3 of 3 \\
\hline Aluminum & 13.94 & 2.16 & 22.7 & 21 of 21 & 11.29 & 1.01 & 13.9 & 10 of 10 & 14.44 & 3 of 3 \\
\hline Cadmium & 0.07 & 0.01 & 0.10 & 21 of 21 & 0.06 & 0.01 & 0.08 & 10 of 10 & 0.10 & 3 of 3 \\
\hline Copper & 2.33 & 0.49 & 6.13 & 21 of 21 & 2.00 & 0.15 & 2.26 & 10 of 10 & 1.38 & 3 of 3 \\
\hline Manganese & 2.71 & 1.18 & 12.35 & 21 of 21 & 0.88 & 0.38 & 2.10 & 10 of 10 & 2.44 & 3 of 3 \\
\hline Thorium & 7.56 & 0.61 & 9.94 & 21 of 21 & 8.29 & 0.61 & 9.98 & 10 of 10 & 9.66 & 3 of 3 \\
\hline Zinc & 1.67 & 0.82 & 6.89 & 21 of 21 & 4.35 & 2.52 & 12.14 & 10 of 10 & 0.94 & 3 of 3 \\
\hline $\begin{array}{l}\text { (a) PRP = } \\
\text { hatche } \\
\text { (b) } 2 \text { stand } \\
\text { (c) Less th }\end{array}$ & $\begin{array}{l}\text { ggs. } \\
\text { errc } \\
\text { dete }\end{array}$ & & & & & & & & & \\
\hline
\end{tabular}

\subsection{Discussion}

This discussion addresses the significance and limitations of surveillance results for radionuclides and metals in Canada geese from the Hanford Site and reference areas. A major limiting factor in the evaluation of contaminants in Canada goose liver is the relatively small number of geese sampled in recent years and the associated restrictions on statistical robustness of the data. This limitation applies primarily to the metals data. Environmental surveillance at the Hanford Site was reduced following phase-out of the single-pass reactors and final closure of N Reactor. Annual surveillance sampling includes groundwater, seeps, river water, sediment, and other biota, including soil and vegetation, on a rotating schedule. The current design is supported by an extensive historical database of sampling and results that provide a thorough and comprehensive understanding of the fate of contaminants in Hanford Site environs. This base of information is enhanced by additional ongoing site-specific ecological risk assessments being conducted by DOE and its Hanford Site contractors. The numbers of geese collected in 2003, 2005, and 2007 as an annual stand-alone effort would be inadequate to meet the broader objectives of the surveillance program if the other surveillance activities involving other environmental media were not conducted. This assessment of contaminants in Canada geese has been conducted 
singularly without addressing contaminant data in other Hanford Site environmental media and, as such, does not constitute a risk assessment. Instead, the report has been written as an attempt to characterize our knowledge about the state of contaminant monitoring in Canada geese and provide some perspective on evaluating the potential impacts of those contaminants on Canada geese.

\subsubsection{Radionuclides}

The discussion of radionuclides focuses first on activation products and then on fission products. This organization parallels historic site operations in that during the operation of single-pass reactors, activation products dominated the releases to the Columbia River. Since the shutdown of the single-pass reactors, radiological characterization of Hanford Site environs have become dominated by fission products, of which a large component outside site facilities has been derived from atmospheric fallout. The third section addresses dose estimates to Canada geese.

\subsubsection{Activation Products}

Because most of the activation products associated with single-pass reactor operations have decayed to stable isotopes, our focus is on cobalt-60 measured by gamma spectroscopy in muscle samples. Cobalt-60 is an activation product found as a minor (trace) dissolved constituent of liquid effluents of single-pass reactors (Healey et al. 1958), with a half-life of approximately 5.2 years. Radioactive metal particles containing elevated concentrations of cobalt-60 were discharged to the Columbia River in reactor effluent during the single-pass reactor operations. These particles have been deposited on islands and along the shoreline of the Columbia River (Sula 1980; Cooper and Woodruff 1993). In the 1970s, concentrations of cobalt-60 were frequently detected in various abiotic environmental media. Richard and Sweany (1977) reported concentrations of cobalt-60 in goose embryos and eggshells collected from the Hanford Reach. Their values were expressed in $\mathrm{pCi} / \mathrm{kg}$ of ash weight and are not directly comparable to surveillance data. However, since then, environmental concentrations have dropped to below detection levels. Without the operation of the production reactors, there is no production of cobalt-60 at DOE facilities on the Hanford Site, and it presents no substantive radiological hazard to Canada geese or those animals or human hunters that could consume them.

\subsubsection{Fission Products}

Cesium-137 is a gamma emitter of special importance because it is chemically similar to potassium, which is found in edible muscle tissue. On the Hanford Site, the primary sources of cesium-137 contamination are associated with waste management activities in the 200 Area. Cesium-137 has never been a major component of radiological liquid discharges to the Columbia River at the Hanford Site, as it is neither an activation product associated with single-pass reactor operations nor a significantly mobile component of contaminated groundwater. Environmental levels of cesium-137 in the river are attributable mainly to atmospheric fallout. Before 1994, the Hanford Site had several low-level waste ponds associated with waste management in the 200 Areas. These ponds were a source of exposure to low levels of radionuclides for waterfowl (Poston and Cooper 1994); however, they were rarely used by Canada geese because the Columbia River provided more suitable habitat. Mallard ducks were the most common species sampled at the waste ponds. With the closure of the last pond (B pond) in 1994, monitored levels of cesium-137 have dropped below detection limits in waterfowl. 
Strontium-90 is chemically similar to calcium and accumulates in hard tissues rich in calcium such as bones, antler, and shells, including eggshells. Hard-tissue concentrations of strontium-90 reflect that organism's exposure; however, strontium-90 in hard tissue generally does not contribute much to human dose because it does not accumulate in edible tissue. Contaminated groundwater entering the Columbia River via shoreline springs near the $100-\mathrm{N}$ and $100-\mathrm{H}$ Areas is the primary Hanford source for strontium-90. However, in 2001, the contribution to the river from these springs was less that $4.3 \%$ of the contribution from historic fallout from atmospheric nuclear weapons testing. In 1990, the contribution was about 11\% (Jaquish 1993). While Rickard has identified a reed canary grass to goose pathway along the Columbia River (Rickard and Price 1990), levels of strontium-90 measured in goose muscle, bone, or eggshells have not attained levels that would result in estimated dose levels in excess of those designated to protect populations of wildlife and have, in recent years, declined to more benign levels close to the limit of detection. DOE guidance has adopted a value of $0.1 \mathrm{rad} / \mathrm{d}$ as protective of terrestrial animals (DOE 2002).

Cesium-137 concentrations in goose muscle and in other biota from the Hanford Site now are at levels close to or below the detection limits for the radionuclides (Stegen et al. 2006). Hanford Site waste management practices and the chemical propensity for cesium-137 adsorb to sediment have effectively sequestered the radionuclide such that it does not migrate through Hanford Site environs at levels that can be readily measured. The ability to measure strontium- 90 has fared a little better because the radiochemical methodology for strontium-90 frequently can detect concentrations an order of magnitude lower than cesium-137 in environmental media. The decrease of strontium-90 in eggshells through time is similar to a decrease observed in fish samples collected over the same period (Poston 1994). Because of its affinity for hard tissue, strontium-90 has proven useful for following trends in the environment with goose eggshells as well as deer antlers (Tiller and Poston 2000), bone samples of rabbits and deer (Poston and Cooper 1994), and in Asiatic clams (Corbicula fluminea).

\subsubsection{Radionuclide Dose Rates}

The relative risk to geese resulting from the accumulation of radionuclides in their tissue can be assessed by using the maximum observed concentrations to calculate an estimated dose rate. Internal dose conversion factors (DCFs) were taken from the RESRAD-BIOTA program (Interagency Steering Committee on Radiation Standards 2004) and Amiro (1997). The DCFs, when multiplied by the maximum observed concentration in a tissue, produces an estimated dose rate. The DCFs are conservative in that they assume all the energy from gamma emissions is adsorbed by the tissue when, in fact, much of the energy is dispersed into the surrounding environment when the gamma photon exits the animal. All the energy from beta decay is adsorbed by the organism. Dose rates resulting from strontium-90 include the beta decay emissions of yttrium-90, the radioactive progeny of strontium- 90 . Dose rates are compared to the proposed benchmark of $0.1 \mathrm{rad} /$ day for populations of terrestrial organisms (DOE 2002). All the radionuclides evaluated in this assessment fell well below the screening level of $0.1 \mathrm{rad} /$ day (Table 4.5).

The hazard to developing goose embryos from strontium-90 in the eggshell is mitigated in part by adsorption of the beta particles within the shell matrix, the inner membrane, and albumin of the egg. Beta particles are effectively attenuated by liquids and solids, and the majority of emissions from the eggshell would not reach the developing embryo until its body filled the egg. At that time, the emissions would affect the developing epidermis of the embryo. To bracket the maximum dose rate, we can assume that 
tissue adjacent to the shell would receive the same exposure as the shell matrix. The maximum strontium-90 concentration in eggshell was observed in 1991 and was $3.15 \mathrm{pCi} / \mathrm{g}$. Based on the dose conversion factor of $5.78 \times 10^{-5} \mathrm{rad} / \mathrm{day}$ per $\mathrm{pCi} / \mathrm{g}$, the associated dose rate is $1.8 \times 10^{-4} \mathrm{rad} / \mathrm{day}$ and is well below the guidance level of $0.1 \mathrm{rad} /$ day.

Table 4.5. Conservative Radiological Dose Rates Associated with Maximum Radionuclide Concentrations in Canada Goose Tissue Samples Collected from 1971-2005

\begin{tabular}{|c|c|c|c|c|c|}
\hline Radionuclide & Emissions & $\begin{array}{c}\text { Dose Conversion } \\
\text { Factor } \\
(\mathrm{rad} / \text { day per } \mathrm{pCi} / \mathrm{g} \\
\text { wet } \mathrm{wt})^{(\mathrm{a})}\end{array}$ & $\begin{array}{c}\text { Maximum } \\
\text { Concentration } \\
\text { (pCi/g wet wt) }\end{array}$ & Year & $\begin{array}{l}\text { Screening Dos } \\
\text { Rate (rad/day) }\end{array}$ \\
\hline Phosphorus-32 & $\beta^{-}$ & $3.56 \times 10^{-05}$ & 1.19 & 1971 & $4.23 \times 10^{-05}$ \\
\hline Cobalt-58 & $\mathrm{EC}, \beta^{+}, \gamma$ & $5.15 \times 10^{-05}$ & 0.57 & 1972 & $2.94 \times 10^{-05}$ \\
\hline Zinc-65 & $\mathrm{EC}, \gamma$ & $3.01 \times 10^{-05}$ & 1.32 & 1971 & $3.98 \times 10^{-05}$ \\
\hline Manganese-54 & $\mathrm{EC}, \gamma$ & $4.30 \times 10^{-05}$ & $0.02(\mathrm{MDC})^{(\mathrm{b})}$ & 1977 & $8.60 \times 10^{-07}$ \\
\hline Europium-152 & $\mathrm{EC}, \beta^{-}, \beta^{+}, \gamma$ & $6.52 \times 10^{-05}$ & 4.25 & 1971 & $2.77 \times 10^{-04}$ \\
\hline Zirconium-niobium-95 & $\beta, \gamma$ & $8.52 \times 10^{-05}$ & $0.02(\mathrm{MDC})$ & 1977 & $1.70 \times 10^{-06}$ \\
\hline Cobalt-60 & $\beta, \gamma$ & $1.33 \times 10^{-04}$ & 0.17 & 1974 & $2.26 \times 10^{-05}$ \\
\hline Cesium- $137^{(\mathrm{c})}$ & $\beta, \gamma$ & $4.33 \times 10^{-05}$ & 3.73 & 1976 & $1.61 \times 10^{-04}$ \\
\hline Strontium- $90^{(\mathrm{c})}$ (bone) & $\beta^{-}$ & $5.78 \times 10^{-05}$ & 0.72 & 1995 & $4.16 \times 10^{-05}$ \\
\hline Strontium- $90^{(\mathrm{c})}$ (muscle) & $\beta^{-}$ & $5.78 \times 10^{-05}$ & 0.017 & 1972 & $9.83 \times 10^{-07}$ \\
\hline Strontium- $90^{(\mathrm{c})}\left(\right.$ shell $\left.^{(\mathrm{d})}\right)$ & $\beta^{-}$ & $5.78 \times 10^{-05}$ & 3.15 & 1991 & $1.82 \times 10^{-04}$ \\
\hline \multicolumn{6}{|c|}{ Dose conversion factors taken from RESRAD-BIOTA code (Interagency Steering Committee on Radiation } \\
\hline \multicolumn{6}{|c|}{ (b) Minimum detectable concentration; value reported was less than detection limit shown. } \\
\hline \multicolumn{6}{|l|}{ (c) $\operatorname{Ir}$} \\
\hline \multicolumn{6}{|l|}{ (d) Calculated as dose 1} \\
\hline
\end{tabular}

\subsubsection{Metals}

The evaluation of metals in Canada goose tissues involved a much smaller data set than that for radionuclides and focused primarily on the Group I metals. Information on Group II metals may be found in Appendixes A and B. Without a tool like radiological dose assessment to put tissue concentrations of contaminants in perspective, the evaluation of metals in goose tissue employed other evaluation techniques. We addressed the question of location effects with parametric statistical analysis to determine if metal concentrations in goose liver indicated greater exposure for geese collected on the Hanford Site relative to geese collected at offsite reference locations upstream and distant to the site. In addition, metal concentrations in liver of Canada geese from this study were compared to reported levels of metals in other waterfowl across the country. This comparison does not necessarily indicate adverse conditions at Hanford or elsewhere, but it does indicate where the distribution of metals departs from the norm as defined by other data sets.

\subsubsection{Location Effects}

Seven of eleven Group I metals were elevated in livers of Hanford Reach geese when compared to Canada geese collected from offsite reference areas. The primary vector of accumulation for these metals 
is the food chain that, for Canada geese, is more terrestrial than aquatic. Geese are preferential grazers and feed on emergent grasses (reed canary grass along the shoreline, along with other plants in the riparian zone). After the juveniles fledge, the potential for grazing in adjacent agricultural fields increases. While concentrations of the metals were elevated in onsite geese compared to samples collected in offsite geese, the source and specific pathways for these metals are unknown. Some shoreline areas have groundwater seepage with distinctively elevated concentrations of chromium, so this is a possible source of exposure for geese feeding in these riparian areas. Metal-based pesticides, which could account for the elevated levels of arsenic, lead, and possibly mercury, may have been applied to abandoned orchards and fields on the Hanford Site. Sources of copper and thallium are unknown.

\subsubsection{Comparison to Metals Concentrations in Liver of Canada Geese to Other Waterfowl}

While the analysis indicates statistically significant differences in liver concentrations by sampling region, the question of biological and toxicological implications associated with the increased hepatic concentrations remains. Many of these metals, while toxic at elevated concentrations, are essential micronutrients (e.g., arsenic, chromium, copper, manganese, selenium, and zinc). Lead, mercury, aluminum, thallium, and cadmium are considered nonessential metals with little if any benefit to life forms.

To evaluate the biological and toxicological implications, hepatic concentrations of metals in geese sampled on the Hanford Site were compared to values published in the literature for both toxicological benchmarks in waterfowl of the family Anatidae and the range of hepatic metal concentrations for metals in other species of waterfowl across the United States. Toxicity benchmarks have been compiled in the ERED (USACE/EPA 2005), and the USGS Contaminants Exposure and Effects Database (Rattner et al. 2006) contains information on the levels of metals reported in waterfowl collected in North America. This second database provides an indication of the range of metal concentrations in the tissues of wild waterfowl, but in most cases, the potential for these fowl to be exposed to elevated levels of metals is unknown; the summarized data simply provide a point of reference. A comprehensive table and supporting narrative of the literature review is provided in Appendix B (Table B.1).

Data were not available for Canada geese in either of these databases, so our assessment used results for other waterfowl of the family Anatidae, including lesser snow geese (Chen (formerly Anser) caerulescens caerlescens; Hui et al. 1998), the black duck (Anas rubripes), canvasback (Aythya valisineria), greater scaup (Aythya marila), and redhead (Aythya americana). Data for these last four species were obtained primarily from Rattner et al. (2006). Data in these reports consisted of listings of means, medians, associated estimates of uncertainty (e.g., standard deviation, standard error), raw data, or maximums.

The data for the Group I metals have been summarized for the Hanford Site Canada goose data, literature survey of waterfowl, and the toxicological benchmarks and biomarkers in Figure 4.8. Comparisons were made by defining the spread of the data (minimum value to maximum value) with a narrow striped band. Symbols (inverted triangles) in the band show the overall mean metal concentration for 2003, 2005, and 2007 samples for the Hanford Site (solid) and the offsite locations (open). The values reported were taken from Table A.2 and Appendix B. Faded sections of the band with an arrow pointing to the left indicate some results in the data set were reported at less than detection concentrations. 


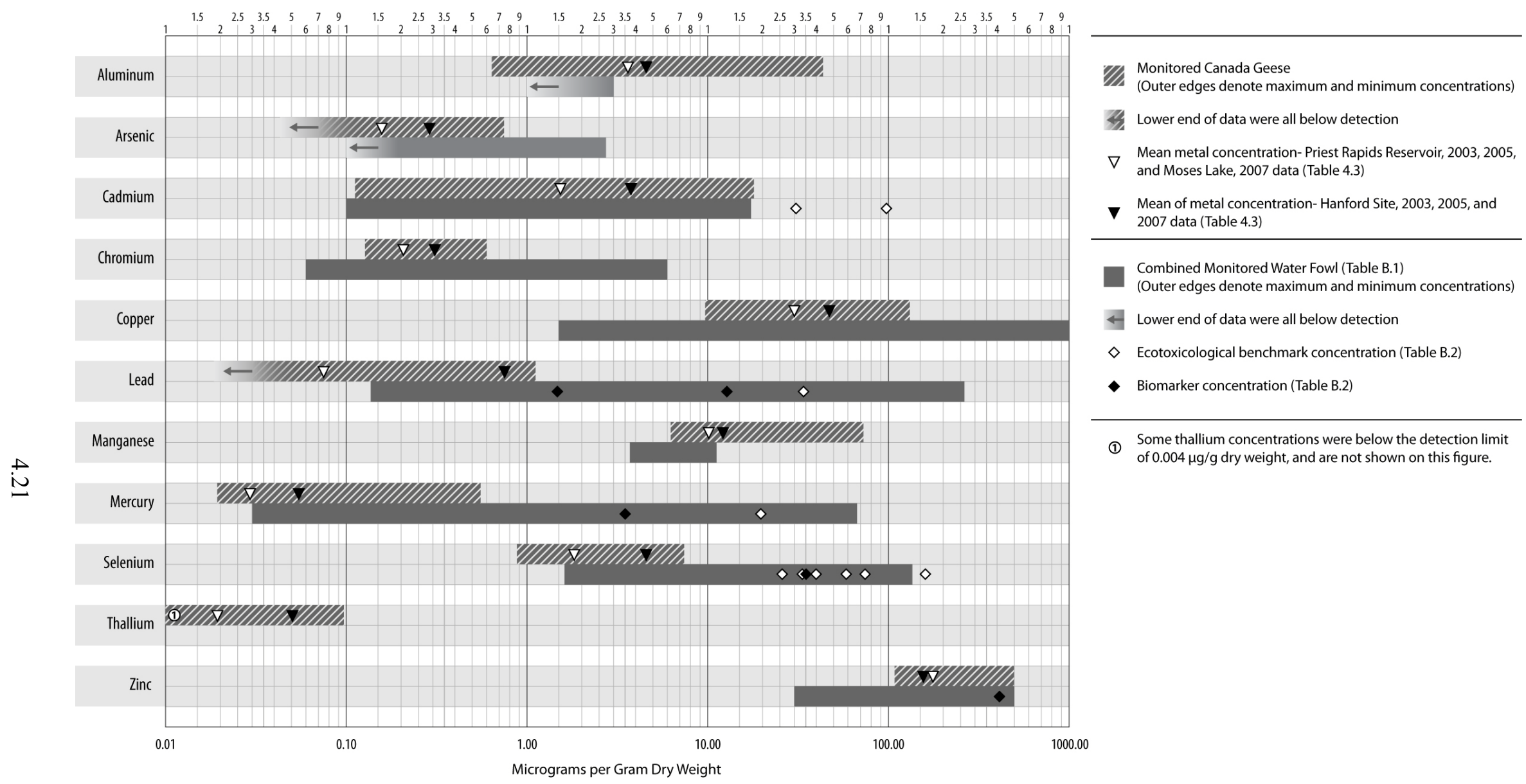

Figure 4.8. Comparison of the Concentrations of Hepatic Metals in Geese from the Hanford Site and Associated Reference Areas with Values Obtained in a Review of Technical Literature of Other Waterfowl 
For the literature data, a separate band was constructed showing the range (minimum and maximum reported values) taken from Table B.1. For chromium, the range of the data was not reported and only the range of reported means is presented. Symbols for available ecotoxicological benchmarks (empty diamond) or biomarker concentrations (solid diamond) are reported for cadmium, lead, mercury, selenium, and zinc (Table B.2).

The literature review provided meaningful comparisons for the majority of Group I metals (Figure 4.8). The exceptions were aluminum and thallium, for which there was a dearth of reported liver concentrations in waterfowl. Only the range of manganese concentrations in Hanford Site goose livers were in excess of literature values reported in other waterfowl. Ecotoxicological benchmarks and biomarkers exceeded the maximum observed concentrations of cadmium, lead, mercury, selenium, and zinc in Hanford Site Canada goose liver samples, suggesting that there is low probability of risk to geese associated with these metals.

\subsubsection{Metals in Canada Goose Eggshells}

Heavy metal concentrations in eggshells were comparable to concentrations found for other waterfowl and shorebirds at uncontaminated and contaminated sites (Table 4.6) (Rodriguez-Navarro et al. 2002; Morera et al. 1997; Currie and Valkama 1998; Rickard and Schuler 1990). It has been proposed that birds eliminate heavy metal by excretion and deposition in feathers and eggs (Burger 1994). Although eggshells provide an efficient and effective way to monitor for metals in biota, little is published on the comparative distribution of metals in goose or waterfowl tissues and eggshells. Studies on house sparrows (Passer domesticus) indicate that eggshells were the least enriched tissue for metal accumulation compared to other soft tissues, including liver, muscle, heart, stomach, brain, egg contents, lung, bone, and feathers (Swaileh and Sansur 2006). Other studies suggest that contaminants are not generally passed from adult to egg. Studies of grackles (Bryan et al. 2003) and eiders (Grand et al. 2002) found selenium was the only contaminant for which there was a relationship between levels in adults and egg contents. In eiders, there was no relationship between contaminant levels and hatching rate. Metals may be passively excreted in eggs and eggshells, but this would be counter adaptive because elevated levels of metals in eggshells would potentially be toxic to the developing embryo if mobilized from the shell. If metals were present in the yolk or albumen, they could also exert a toxic effect. Assuming that the tissue distribution of metals indicated in house sparrows holds for waterfowl, the excretion of metals in eggshells and egg contents is likely at best passive and incidental to the function of reproduction.

Conclusions regarding the relationship between metal concentrations in Canada geese eggshells and hatching success are limited by the number of samples, the fact that data were collected for only a single nesting season, and the lack of information on other factors that may affect hatching success. For example, data are lacking on the contaminant burdens of nesting geese and on the resulting hatching success and clutch size. Also, collected eggshells may be from geese that migrated to the Hanford Reach, which casts additional uncertainty regarding the contaminant exposure history. Overall, no conclusions can be derived regarding the observations on metal concentrations in eggshells, hatching success, and general proximity to industrialized areas on the Hanford Site. However, these data sets provide baseline information regarding the range of metal concentrations in eggshells compared to liver. Eggshells are most appropriate for monitoring metals that may behave as chemical analogues of calcium, such as strontium-90. 
Table 4.6. Mean Heavy Metal Concentrations ( $\mu \mathrm{g} / \mathrm{g}$ dry wt) in Eggshells from Canada Geese Compared to Those of Other Birds Collected from Reference (i.e., Background) or Polluted Sites, 2001 Data

\begin{tabular}{|c|c|c|c|c|c|}
\hline Species & Mean & $2 \mathrm{SE}^{(\mathrm{a})}$ & Range & Method & Source \\
\hline \multicolumn{6}{|c|}{ Copper } \\
\hline Canada geese (unhatched) & 2.00 & 0.154 & & ICP-MS & This study \\
\hline Canada geese (hatched) & 2.33 & 0.49 & & ICP-MS & This study \\
\hline Canada geese $(1989 ; \mathrm{N}=3)$ & 12.2 & & $8.5-16$ & $\mathrm{XRF}$ & Rickard and Schuler (1990) \\
\hline Ring-billed gull $(\mathrm{N}=3)$ & 8.5 & & $8.1-9.1$ & $\mathrm{XRF}$ & Rickard and Schuler (1990) \\
\hline Great blue heron $(\mathrm{N}=8)$ & 9.0 & & $7.0-11$ & $\mathrm{XRF}$ & Rickard and Schuler (1990) \\
\hline Osprey $(\mathrm{N}=3)$ & 9.3 & & $7.2-12$ & $\mathrm{XRF}$ & Rickard and Schuler (1990) \\
\hline Audouin's gull & 2.14 & 0.19 & & ICP-MS & Morera et al. (1997) \\
\hline Clapper rail (reference) & 1.37 & 0.36 & & ICP-MS & Rodriguez-Navarro et al. (2002) \\
\hline Clapper rail (polluted) & 1.71 & 0.25 & & ICP-MS & Rodriguez-Navarro et al. (2002) \\
\hline Curlew (reference 1) & 7.7 & 0.56 & & ICP-MS & Currie and Valkama (1998) \\
\hline Curlew (reference 2) & 8.03 & 0.48 & & ICP-MS & Currie and Valkama (1998) \\
\hline Curlew (polluted) & 9.56 & 1.22 & & ICP-MS & Currie and Valkama (1998) \\
\hline \multicolumn{6}{|c|}{ Manganese } \\
\hline Canada geese (unhatched) & 0.88 & 0.38 & & ICP-MS & This study \\
\hline Canada geese (hatched) & 2.71 & 1.18 & & ICP-MS & This study \\
\hline Audouin's gull & 0.29 & 0.12 & & ICP-MS & Morera et al. (1997) \\
\hline Clapper rail (reference) & 5 & 1.11 & & ICP-MS & Rodriguez-Navarro et al. (2002) \\
\hline Clapper rail (polluted) & 7 & 1.31 & & ICP-MS & Rodriguez-Navarro et al. (2002) \\
\hline \multicolumn{6}{|c|}{ Mercury } \\
\hline Canada geese (unhatched) & 0.002 & & $<$ Det. -0.0 .009 & CVAA & This study \\
\hline Canada geese (hatched) & 0.001 & & $<$ Det. -0.002 & CVAA & This study \\
\hline Audouin's gull & 0.22 & 0.03 & & CVAA & Morera et al. (1997) \\
\hline Clapper rail (reference) & 0.105 & 0.04 & & ICP-MS & Rodriguez-Navarro et al. (2002) \\
\hline Clapper rail (polluted) & 0.37 & 0.23 & & ICP-MS & Rodriguez-Navarro et al. (2002) \\
\hline \multicolumn{6}{|c|}{ Zinc } \\
\hline Canada geese ( $100 \%$ hatched) & 1.67 & 0.82 & & ICP-MS & This study \\
\hline Canada geese (unhatched) & 4.35 & 2.52 & & ICP-MS & This study \\
\hline Canada geese $(1989 ; \mathrm{N}=3)$ & 1.6 & & $<$ Det. -4.8 & $\mathrm{XRF}$ & Rickard and Schuler (1990) \\
\hline Ring-billed gull $(\mathrm{N}=3)$ & 9.4 & & $6.3-13$ & $\mathrm{XRF}$ & Rickard and Schuler (1990) \\
\hline Great blue heron $(\mathrm{N}=8)$ & 6.7 & & $<$ Det. -16 & $\mathrm{XRF}$ & Rickard and Schuler (1990) \\
\hline Osprey $(\mathrm{N}=3)$ & 14 & & $3.2-23$ & $\mathrm{XRF}$ & Rickard and Schuler (1990) \\
\hline Audouin's gull & 6.58 & 0.57 & & ICP-MS & Morera et al. (1997) \\
\hline Clapper rail (reference) & 4.8 & 1.31 & & ICP-MS & Rodriguez-Navarro et al. (2002) \\
\hline Clapper rail (polluted) & 6.33 & 1.83 & & ICP-MS & Rodriguez-Navarro et al. (2002) \\
\hline Curlew (reference 1) & 3.77 & 1.08 & & ICP-MS & Currie and Valkama (1998) \\
\hline
\end{tabular}


Table 4.6. (contd)

\begin{tabular}{|c|c|c|c|c|c|}
\hline Species & Mean & $2 \mathrm{SE}^{(\mathrm{a})}$ & Range & Method & Source \\
\hline \multicolumn{6}{|c|}{ Zinc } \\
\hline Curlew (reference 2) & 4.53 & 0.76 & & ICP-MS & Currie and Valkama (1998) \\
\hline Curlew (polluted) & 5.2 & 2.68 & & ICP-MS & Currie and Valkama (1998) \\
\hline \multicolumn{6}{|c|}{ Lead } \\
\hline Canada geese (hatched) & 0.079 & 0.033 & & ICP-MS & This study \\
\hline Canada geese (unhatched) & 0.121 & 0.105 & & ICP-MS & This study \\
\hline Clapper rail (reference) & 0.23 & 0.555 & & ICP-MS & Rodriguez-Navarro et al. (2002) \\
\hline Clapper rail (polluted) & 0.37 & 0.227 & & ICP-MS & Rodriguez-Navarro et al. (2002) \\
\hline \multicolumn{6}{|c|}{ Selenium } \\
\hline Canada geese (hatched) & 0.203 & 0.005 & & ICP-MS & This study \\
\hline Canada geese (unhatched) & 0.206 & 0.012 & & ICP-MS & This study \\
\hline Clapper rail (reference) & 0.71 & 0.155 & & ICP-MS & Rodriguez-Navarro et al. (2002) \\
\hline Clapper rail (polluted) & 0.9 & 0.113 & & ICP-MS & Rodriguez-Navarro et al. (2002) \\
\hline \multicolumn{6}{|c|}{$\begin{array}{l}\text { (a) } 2 \text { standard errors. } \\
\text { CVAA }=\text { cold vapor atomic absorption. } \\
\text { ICP-MS }=\text { inductively coupled plasma mass spectrometry. } \\
\text { XRF }=\text { x-ray fluorescence. }\end{array}$} \\
\hline
\end{tabular}

\subsection{Conclusions}

Monitoring data describing the contaminant concentrations of Canada geese for radionuclides do not indicate any significant exposures of these waterfowl to contaminants that may compromise their health, either as individuals or as a population. Data collected from 1971 through 2005 do not indicate that Canada geese accumulated radionuclides to levels in excess of conservative guidelines established for the protection of biota. Eggshells and bone samples are good media for tracking strontium-90.

Monitoring of waterfowl at the Hanford Site initially focused on the hazards posed by consumption of waterfowl by hunters. Much of the emphasis in these early collections was on ducks collected from the Columbia River and low-level waste management ponds on the Central Plateau. At the time of singlepass reactor operations up through 1971, a preponderance of Hanford Reach Canada geese nested on the upper islands (see Section 2). Geese utilizing the upper islands potentially had greater exposure to reactor effluents due to closer proximity to effluents than those nesting on the lower islands. Early assessments of risk to the public who consumed waterfowl in the Mid-Columbia area concluded that the levels of radioactivity in Hanford Reach waterfowl did not constitute a significant vector to human populations residing in the Mid Columbia (Hanson and Case 1963; see also annual environmental monitoring reports for the Hanford Site at http://hanford-site.pnl.gov/envreport/). The influx of migratory waterfowl into the Mid-Columbia Basin during the hunting seasons further reduced the probability that a hunter would harvest and consume resident ducks or geese. Consequently, risk of human exposure to Hanford contaminants was reduced. The banding studies (Section 3) provide an indication of how far resident geese disperse during migrations. Assuming that these geese accumulated contaminants at the Hanford Site, the risk to hunters at these distant locations is mitigated also by the low probability of harvesting 
multiple birds that had resided at the Hanford Site. Additionally, the levels of site contaminants, if elevated above background, will equilibrate to background due to decay (radionuclides) and biological turnover.

Hepatic metal concentrations of seven metals in Canada geese collected at locations within the Hanford Site exceeded concentrations collected at the offsite reference location. When compared with other lines of evidence, hepatic metal concentrations did not indicate that exposure of Canada geese to metals at the site presents a threat of elevated risk. Comparisons of hepatic metal concentrations to other waterfowl suggested that only manganese levels were greater in Canada geese collected at the Hanford Site than observed elsewhere in the country; all other concentrations of Group I metals were lower. There is some uncertainty in the benchmarks available for waterfowl because they come from different species and the benchmarks are limited in number. The concentrations of Group I metals were below reported ecotoxicological screening benchmarks and biomarkers.

Low concentrations of contaminants found in Canada geese that inhabit the Hanford Reach is consistent with other aspects of Canada goose population monitoring, indicating that the Hanford Reach Canada goose population is generally healthy and robust. 


\subsection{References}

65 FR 37253-37257. June 13, 2000. Presidential Proclamation, "Establishment of the Hanford Reach National Monument." Federal Register.

Amiro BD. 1997. "Radiological Dose Conversion Factors for Generic Non-Human Biota Used for Screening Potential Ecological Impacts." Journal of Environmental Radioactivity 35(1):37-51.

Ball IJ, EL Bowhay, and CF Yocom. 1981. Ecology and Management of the Western Canada Goose in Washington. Biological Bulletin No. 17, Washington Department of Game, Olympia.

Becker CD. 1990. Aquatic Bioenvironmental Studies: The Hanford Experience: 1944-1984. Elsevier Publishing Company, New York.

Bjornstad BN. 2006. Past, Present, Future Erosion at Locke Island. PNNL-15941, Pacific Northwest National Laboratory, Richland, Washington.

Bryan AL Jr, WA Hopkins, JA Baionno, and BP Jackson. 2003. "Maternal Transfer of Contaminants to Eggs in Common Grackles (Quiscalus quiscala) Nesting on Coal Fly Ash Basins." Archives of Environmental Contamination and Toxicology. 45:273-277.

Burger J. 1994. "Heavy Metals in Avian Eggshells: Another Excretion Method." Journal of Toxicology and Environmental Health 41:207-220.

Bustnes JO, KE Erikstad, JU Skaare, V Bakken, and F Mehlum. 2003. "Ecological Effects of Organochlorine Pollutants in the Arctic: A Study of the Glaucous Gull." Ecological Applications 13:504-515.

DART. 2008. "DART Streamflow for Columbia River Basin." Columbia Basin Research, School of Aquatic \& Fishery Sciences, University of Washington, Seattle. Available at http://www.cbr.washington.edu/dart/headwater_com.html (February 2010).

Cooper AT and RW Woodruff. 1993. Investigations of Exposure Rates and Radionuclides and Trace Metal Distributions Along the Hanford Reach of the Columbia River. PNL-8789, Pacific Northwest Laboratory, Richland, Washington.

Cooper RG. 2001. "Handling, Incubation and Hatchability of Ostrich (Struthio camelus var. domesticus) Eggs: A Review." Journal of Applied Poultry Research 10:262-273.

Culbertson JL, LL Cadwell, and IO Buss. 1971. "Nesting and Movement of Canada Geese on the Snake River in Washington." The Condor 73:230-236.

Currie D and J Valkama. 1998. "Limited Effects of Heavy Metal Pollution on Foraging and Breeding Success in the Curlew (Numenius arquata)." Environmental Pollution 101:253-261.

Cushing CE, DG Watson, AJ Scott, and JM Gurtisen. 1980. Decline of Radionuclides in Columbia River Biota. PNL-3269, Pacific Northwest Laboratory, Richland, Washington. 
DeWaard BK. 1981. Reproduction and Ecology of Canada Geese on the Hanford Reservation, 19531980. Masters thesis, Washington State University, Pullman.

Dirkes RL and RW Hanf, Jr. 1996. Hanford Site Environmental Report for Calendar Year 1995. PNNL-11139, Pacific Northwest National Laboratory, Richland, Washington.

Dirkes RL and RW Hanf, Jr. 1998. Hanford Site Environmental Report for Calendar Year 1997. PNNL-11795, Pacific Northwest National Laboratory, Richland, Washington.

DOE (U.S. Department of Energy). 2007. Environmental Monitoring Plan United States Department of Energy Richland Operations Office. DOE/RL-91-50, Rev. 4, U.S. Department of Energy, Richland Operations Office, Richland, Washington.

DOE (U.S. Department of Energy). 2002. A Graded Approach for Evaluating Radiation Doses to Aquatic and Terrestrial Biota. DOE-STD-1153-2002, U.S. Department of Energy, Washington, D.C. Available at http://www.hss.energy.gov/NuclearSafety/ns/techstds/standard/standard.html (February 2010).

Dunn EH and CD MacInnes. 1987. "Geographical Variation in Clutch Size and Body Size of Canada Geese.” Journal of Field Ornithology 58:355-371.

Eberhardt LE, RG Anthony, and WH Rickard. 1989a. "Survival of Juvenile Canada Geese During the Rearing Period." Journal of Wildlife Management 53:372-377.

Eberhardt LE, RG Anthony, and WH Rickard. 1989b. "Movement and Habitat Use by Great Basin Canada Goose Broods.” Journal of Wildlife Management 53:740-748.

Eberhardt LE, GG Brooks, RG Anthony, and WH Rickard. 1989c. "Activity Budgets of Canada Geese During Brood Rearing." The Auk 106:218-224.

Eeva T and T Lehikoinen. 1995. "Egg Shell Quality, Clutch Size and Hatching Success of the Great Tit (Parus major) and the Pied Flycatcher (Ficedula hypoleuca) in an Air Pollution Gradient." Oecologia 102:312-323.

Fitzner RE and WH Rickard. 1983. "Canada Goose Nesting Performance along the Hanford Reach of the Columbia River, 1971-1981.” Northwest Science 57:267-272.

Fitzner RE, LE Eberhardt, WH Rickard, Jr., and RH Gray. 1994. "Great Basin Canada Goose Nesting on the Mid-Columbia River, Washington: An Historical Perspective and Update, 1981-1990." Northwest Science 68:37-42.

Gochfeld M and JB Grand, JC Franson, PL Flint, and MR Petersen. 2002. "Concentrations of Trace Elements in Eggs and Blood of Spectacled and Common Eiders on the Yukon-Kuskokwim Delta, Alaska, USA.” Environmental Toxicology and Chemistry 21:1673-1678. 
Hanson WC and AC Case. 1963. “A Method of Measuring Waterfowl Dispersion Utilizing Phosphorous-32 and Zinc-65." In Radioecology - Proceedings of the First National Symposium on Radioecology, V Schultz and AW Klement (eds.), pp. 451-454. Reinhold Publishing Company, New York.

Hanson WC and LE Eberhardt. 1971. "A Columbia River Canada Goose Population, 1950-1970." Wildlife Monograph 28, Alliance Communications Group, Lawrence, Kansas.

Hanson WC and RL Browning. 1959. "Nesting Studies of Canada Geese on the Hanford Reservation," 1953-1956. Journal of Wildlife Management 23:124-137.

Healey JW, BV Anderson, HV Clukey, and JK Soldat. 1958. "Radiation Exposure to People in the Vicinity of a Major Production Atomic Energy Plant." In Proceedings of the Second United Nations International Conference on the Peaceful Uses of Atomic Energy, Volume 18, pp. 309-318. United Nations, Geneva.

Hothem RL and AN Powell. 2000. "Contaminants in Eggs of Western Snowy Plovers and California Least Terns: Is There a Link to Population Decline?" Bulletin of Environmental Contamination and Toxicology 65:42-50.

Hope SJ and RE Petersen. 1996. Pore Water Chromium Concentrations at 100-H Reactor Area Adjacent to Fall Chinook Salmon Spawning Habitat of the Hanford Reach, Washington. BHI-00345, Rev. 1, Bechtel Hanford, Inc., Richland, Washington.

Hui CA, JY Takekawa, VV Baranyuk, and KV Litvin. 1998. "Trace Metal Concentrations in Two Subpopulations of Lesser Snow Geese from Wrangel Island, Russia." Archives of Environmental Contamination and Toxicology 34:197-203.

Interagency Steering Committee on Radiation Standards. 2004. RESRAD-BIOTA: A Tool for Implementing a Graded Approach to Biota Dose Evaluation. User's Guide, Version 1. DOE/EH-0676, Interagency Steering Committee on Radiation Standards (ISCORS) Technical Report 2004-02, U.S. Department of Energy, Washington, D.C.

Jaquish RE. 1993. Contribution of Hanford Liquid Effluents to Strontium-90 Levels in Offsite Soils. PNL-8817, Pacific Northwest Laboratory, Richland, Washington.

Jamieson IG and CJ Ryan. 1999. "Causes of low reproductive success of translocated takahe (Porphyrio mantelli) on predator-free islands." Science for Conservation 125. New Zealand Department of Conservation, Wellington, New Zealand.

Johnson DH and TL Shaffer. 1990. "Estimating Nest Success: When Mayfield Wins." The Auk 107:595-600.

Johnson VG, RE Peterson, and KB Olson. 2005. "Heavy metal Transport and Behavior in the Lower Columbia River, USA.” Environmental Monitoring and Assessment 110:271-289. 
Keating JK and DW Harvey. 2003. "Site Security." Section 8 in Hanford Site Historic District, History of the Plutonium Productin Facilities 1943-1990. DOE/RL-97-1047, U.S. Department of Energy, Richland Operations Office, Battelle Press, Columbus, Ohio.

Krapu GL, RE Reynolds, GA Sargeant, and RW Renner. 2004. "Patterns of Variation in Clutch Sizes in a Guild of Temperate-Nesting Dabbling Ducks." The Auk 121:695-706.

Leafloor JO, MRJ Hill, DH Rusch, KF Abraham, and RK Ross. 2000. "Towards Conservation of the Diversity of Canada Geese (Branta canadensis)." In Nesting Ecology and Gosling Survival of Canada Geese on Akimiski Island, Nunavut, Canada, KM Dickson (ed), Canadian Wildlife Service Occasional Paper No. 103, pp. 109-116. Canadian Wildlife Service, Ottawa, Ontario, Canada.

Morera M, C Sampera, S Crespo, L Jover, and X Ruiz. 1997. "Inter- and Intraclutch Variability in Heavy Metals and Selenium Levels in Audouin's Gull Eggs from the Ebro Delta, Spain." Archives of Environmental Contamination and Toxicology 33:71-75.

Patton GW and RL Dirkes. 2007. Summary of Radiological Monitoring of Columbia and Snake River Sediment, 1988-2004. PNNL-16990, Pacific Northwest National Laboratory, Richland, Washington.

Poston TM. 1994. Trends in Radionuclide Concentrations in Hanford Reach Fish, 1982 through 1992. PNL-9960, Pacific Northwest Laboratory, Richland, Washington.

Poston TM and AT Cooper. 1994. A Qualitative Evaluation of Radionuclide Concentrations in Hanford Site Wildlife, 1983 through 1992. PNL-10174, Pacific Northwest Laboratory, Richland, Washington.

Poston TM, RW Hanf, Jr., and RL Dirkes (eds). 2000. Hanford Site Environmental Report for Calendar Year 1999. PNNL-13230, Pacific Northwest National Laboratory, Richland, Washington.

Poston TM, RW Hanf Jr, R Dirkes, and LF Morasch (eds). 2001. Hanford Site Environmental Report for Calendar Year 2000. PNNL-13487, Pacific Northwest National Laboratory, Richland, Washington.

Poston TM, RW Hanf, Jr., RL Dirkes, and LF Morasch (eds). 2002. Hanford Site Environmental Report for Calendar Year 2001. PNNL 13910, Pacific Northwest National Laboratory, Richland, Washington.

Poston TM, RW Hanf Jr, RL Dirkes, and LF Morasch (eds). 2003. Hanford Site Environmental Report for Calendar Year 2002. PNNL-14295, Pacific Northwest National Laboratory, Richland, Washington.

Poston, RM, RW Hanf, RL Dirkes, and LF Morasch (eds). 2004. Hanford Site Environmental Report for Calendar Year 2003. PNNL-14687. Pacific Northwest National Laboratory, Richland, Washington.

Poston, TM, RW Hanf, RL Dirkes, and LF Morasch. 2006. Hanford Site Environmental Report for Calendar Year 2005. PNNL-15892, Pacific Northwest National Laboratory, Richland, Washington.

Poston TM, JP Duncan, and RL Dirkes. 2008. Hanford Site Environmental Report for Calendar Year 2007. PNNL-17603, Pacific Northwest National Laboratory, Richland, Washington. 
Rattner BA et al. 2006. "Contaminant Exposure and Effects--Terrestrial Vertebrates (CEE-TV) Database. Version 6.0. Updated May 2006.” U.S. Geological Survey, Patuxent Wildlife Research Center, Laurel, Maryland. Available at http://www.pwrc.usgs.gov/contaminants-online/ (February 2010).

Raveling DG, JS Sedinger, and DS Johnson. 2000. "Reproductive Success and Survival in Relation to Experience During the First Two Years in Canada Geese." The Condor 102:941-945.

Reed ET, J Bety, J Mainguy, G Gauthier, and JF Giroux. 2003. "Molt Migration in Relation to Breeding Success in Greater Snow Geese." Arctic 56:76-81.

Rickard WH and KR Price. 1990. "Strontium-90 in Canada Goose Eggshells and Reed Canary Grass from the Columbia River, Washington." Environmental Monitoring and Assessment 14:71-76.

Rickard WH and CA Schuler. 1990. "Mineral Composition of Eggshells of Wild Birds from the Columbia Basin, Washington." Northwestern Naturalist 71:5-8.

Rickard WH and HA Sweany. 1977. "Radionuclides in Canada Goose Eggs." In Biological Implications of Metals in the Environment. CONF-750985, U.S. Department of Energy Technical Information Center, Oak Ridge, Tennessee.

Rodriguez-Navarro AB, KF Gaines, CS Romanek, and GR Masson. 2002. "Mineralization of Clapper Rail Eggshell from a Contaminated Salt Marsh System." Archives of Environmental Contamination and Toxicology 43:449-460.

Sargeant AB and DG Raveling. 1992. "Mortality during the breeding season." In Ecology and Management of Breeding Waterfowl, BDJ Batt, AD Afton, MG Anderson, CD Ankney, DH Johnson, JA Kadlec, and GL Krapu (eds.). Northern Prairie Wildlife Research Center, University of Minnesota Press, Minneapolis. Available at http://www.npwrc.usgs.gov/resource/birds/ecomanag/chap12/chap12.htm (February 2010).

Shlein B. 1992. The Health Physics and Radiological Health Handbook. Revised edition. Scinta, Inc., Silver Spring, Maryland.

Sinnott RW. 1984. "Virtues of the Haversine.” Sky Telescope 68:158.

Stegen JA, RE Durham, and KD Hand. 2006. "Monitoring of Fish and Wildlife for Hanford-Produced Contaminants." In Hanford Site Environmental Report for Calendar Year 2005. TM Poston, RW Hanf, RL Dirkes, and LF Morasch (eds). PNNL-15892, Pacific Northwest National Laboratory, Richland, Washington.

Sula MJ. 1980. Radiological Survey of Exposed Shorelines and Islands of the Columbia River between Vernita and the Snake River Confluence. PNL-3127, Pacific Northwest Laboratory, Richland, Washington.

Swaileh KM and R Sansur. 2006. "Monitoring urban heavy metal pollution using the House Sparrow (Passer domesticus)." Journal of Environmental Monitoring 8:209-213. 
Terres JK. 1980. The Audubon Society Encyclopedia of North American Birds. Alfred A. Knopf, New York.

Tiller BL and TM Poston. 2000. "Efficacy of Mule Deer Antlers as Biomonitors of Strontium-90 in the Hanford Site Environment." Journal of Environmental Radioactivity 47:29-44.

Unterweger MP, DD Hoppes, FJ Schima, and JS Coursey. 2006. "Radionuclide Half-Life Measurements Made at NIST." Available at http://physics.nist.gov/PhysRefData/Halflife/halflifeT.html (February 2010).

USACE/EPA (U.S. Army Corps of Engineers/U.S. Environmental Protection Agency). 2005. "The Environmental Residue-Effects Database (ERED).” Available at http://el.erdc.usace.army.mil/ered/ (February 2010).

USGS (U.S. Geological Survey). 2006a. "Bird Banding Laboratory - The North American Bird Banding Program." Available at http://www.pwrc.usgs.gov/bbl/ (February 2010).

USGS (U.S. Geological Survey). 2006b. "USGS Patuxent Wildlife Research Center - Waterfowl (Ducks, Geese and Swans), AOU Numbers 129.0 - 181.0 Longevity Records.” Available at http://www.pwrc.usgs.gov/bbl/homepage/longvlst.cfm (February 2010).

Wiemeyer SN. 2005. Metals and Trace Elements in Eggs of American White Pelicans at Anaho Island, Nevada 2004. U.S. Fish and Wildlife Service, Reno, Nevada.

Yokel J and DA Delistraty. 2003. "Arsenic, lead, and other trace elements in soils contaminated with pesticide residues at the Hanford site (USA)." Environmental Toxicology 18(2):104-114.

Additional information on contaminant levels in Hanford Site waterfowl and the Hanford environs can be found in previous Hanford Site environmental monitoring reports. Reports from 1959 through 2007 are available electronically at http://hanford-site.pnl.gov/envreport/. 


\section{Appendix A}

Supplemental Data Tables on Metal Contaminants in Canada Geese 


\section{Appendix A}

\section{Supplemental Data Tables on Metal Contaminants in Canada Geese}

\section{A.1 Mercury in Liver and Kidney Samples, 2001}

Because of a problem with sample preparation, only mercury was evaluated for goose samples collected in 2002. Median mercury concentrations in goose kidney were slightly higher than median concentrations in liver (Table A.1). The median concentrations in liver collected in 2001 were similar to the median concentrations observed in samples collected in 2003, 2005, and 2007. Maximum values for mercury in liver samples in 2001 ranged from 0.062 to $0.104 \mu \mathrm{g} / \mathrm{g}$ dry wt. These liver concentrations were lower than the maximum liver concentration $(0.157 \mu \mathrm{g} / \mathrm{g}$ dry wt) observed in 2003 from the 100 Areas.

Table A.1. Descriptive Statistics for Concentrations of Mercury in Canada Goose Kidney and Liver Collected in 2001 (blank-corrected data, $\mu \mathrm{g} / \mathrm{g}$ dry wt)

\begin{tabular}{lcccccc}
\hline & Mean & Median & Standard Error & Minimum & Maximum & Count \\
\hline & & \multicolumn{5}{c}{ Kidney } \\
100 Areas & 0.079 & 0.083 & 0.014 & 0.032 & 0.118 & 6 \\
Hanford town site & 0.066 & 0.056 & 0.019 & 0.031 & 0.119 & 4 \\
& & & Liver & & & \\
100 Areas & 0.071 & 0.073 & 0.011 & 0.035 & 0.104 & 6 \\
Hanford town site & 0.046 & 0.046 & 0.006 & 0.023 & 0.062 & 5 \\
\hline
\end{tabular}

\section{A.2 Descriptive Statistics of Metals in Canada Goose Livers}

Tables A.2 and A.3 provide descriptive statistics for Group I and Group II metals in Canada goose livers by year and sampling area. The values reported have not been corrected to significant digits; and it is assumed that for general review, no more than two significant digits should be assumed. Other important factors to consider when reviewing the data are the number of results that were below detection and, at some sampling locations, the actual number of samples collected. 
Table A.2. Descriptive Statistics for Concentrations of Group I Metals in Canada Goose Liver Collected in 2003, 2005, and 2007 (not blank-corrected, $\mu \mathrm{g} / \mathrm{g}$ dry wt)

\begin{tabular}{|c|c|c|c|c|c|c|c|}
\hline Location & Year & Mean & Median & $\begin{array}{l}\text { Standard } \\
\text { Error }\end{array}$ & Minimum & Maximum & Count \\
\hline \multicolumn{8}{|c|}{ Aluminum } \\
\hline \multirow{3}{*}{100 Areas } & 2003 & 11.421 & 5.26 & 6.172 & 2.34 & 54.2 & 8 \\
\hline & 2005 & 2.412 & 2.3 & 0.373 & 1.29 & 3.5 & 5 \\
\hline & 2007 & 1.4 & 1.16 & 0.367 & 0.631 & 2.8 & 5 \\
\hline \multirow{3}{*}{ Hanford town site } & 2003 & 4.485 & 4.485 & 0.495 & 3.99 & 4.98 & 2 \\
\hline & 2005 & 2.482 & 2.61 & 0.232 & 1.86 & 3.18 & 5 \\
\hline & 2007 & 1.153 & 1.24 & 0.101 & 0.836 & 1.41 & 5 \\
\hline Onsite & 2003-07 & 4.586 & 2.475 & 1.752 & 54.2 & 0.631 & 30 \\
\hline Moses Lake & 2007 & 1.967 & 1.77 & 0.353 & 1.2 & 2.89 & 5 \\
\hline \multirow{2}{*}{ Priest Rapids pool } & 2003 & 3.155 & 3.155 & 1.315 & 1.84 & 4.47 & 2 \\
\hline & 2005 & 5.478 & 3.77 & 2.121 & 1.91 & 13.8 & 5 \\
\hline Offsite & 2003-07 & 3.628 & 2.795 & 0.982 & 13.8 & 1.2 & 12 \\
\hline \multicolumn{8}{|c|}{ Arsenic } \\
\hline \multirow{3}{*}{100 Areas } & 2003 & 0.356 & 0.3 & 0.071 & $0.199^{(\mathrm{a})}$ & 0.746 & 8 \\
\hline & 2005 & 0.162 & 0.169 & 0.01 & 0.132 & 0.191 & 5 \\
\hline & 2007 & 0.34 & 0.329 & 0.033 & 0.267 & 0.446 & 5 \\
\hline \multirow{3}{*}{ Hanford town site } & 2003 & 0.199 & 0.199 & 0 & $0.199^{(\mathrm{a})}$ & 0.199 & 2 \\
\hline & 2005 & 0.156 & 0.151 & 0.031 & $0.07^{(\mathrm{a})}$ & 0.245 & 5 \\
\hline & 2007 & 0.398 & 0.396 & 0.015 & 0.366 & 0.445 & 5 \\
\hline Onsite & 2003-07 & 0.284 & 0.256 & 0.027 & 0.746 & 0.07 & 30 \\
\hline Moses Lake & 2007 & 0.1 & 0.1 & 0 & 0.1 & 0.1 & 5 \\
\hline \multirow{2}{*}{ Priest Rapids pool } & 2003 & 0.282 & 0.282 & 0.084 & $0.199^{(\mathrm{a})}$ & 0.366 & 2 \\
\hline & 2005 & 0.159 & 0.141 & 0.021 & $0.103^{(a)}$ & 0.211 & 5 \\
\hline Offsite & 2003-07 & 0.155 & 0.118 & 0.023 & 0.366 & 0.1 & 12 \\
\hline \multicolumn{8}{|c|}{ Cadmium } \\
\hline \multirow{3}{*}{100 Areas } & 2003 & 3.288 & 2.455 & 1.136 & 0.622 & 10.4 & 8 \\
\hline & 2005 & 4.151 & 4.77 & 1.684 & 0.217 & 8.15 & 5 \\
\hline & 2007 & 2.871 & 2.84 & 1.134 & 0.204 & 5.54 & 5 \\
\hline \multirow{3}{*}{ Hanford town site } & 2003 & 8.985 & 8.985 & 6.615 & 2.37 & 15.6 & 2 \\
\hline & 2005 & 2.89 & 1.04 & 1.201 & 0.892 & 6.48 & 5 \\
\hline & 2007 & 2.705 & 0.4 & 1.44 & 0.31 & 6.35 & 5 \\
\hline Onsite & 2003-07 & 3.578 & 2.605 & 0.663 & 15.6 & 0.204 & 30 \\
\hline Moses Lake & 2007 & 0.539 & 0.423 & 0.188 & 0.116 & 0.993 & 5 \\
\hline \multirow{2}{*}{ Priest Rapids pool } & 2003 & 2.395 & 2.395 & 0.595 & 1.8 & 2.99 & 2 \\
\hline & 2005 & 2.149 & 0.904 & 1.038 & 0.682 & 6.11 & 5 \\
\hline Offsite & 2003-07 & 1.519 & 0.937 & 0.487 & 6.11 & 0.116 & 12 \\
\hline
\end{tabular}


Table A.2. (contd)

\begin{tabular}{|c|c|c|c|c|c|c|c|}
\hline Location & Year & Mean & Median & $\begin{array}{l}\text { Standard } \\
\text { Error }\end{array}$ & Minimum & Maximum & Count \\
\hline \multicolumn{8}{|c|}{ Chromium } \\
\hline \multirow{3}{*}{100 Areas } & 2003 & 0.418 & 0.406 & 0.024 & 0.333 & 0.548 & 8 \\
\hline & 2005 & 0.202 & 0.2 & 0.007 & 0.181 & 0.22 & 5 \\
\hline & 2007 & 0.278 & 0.27 & 0.032 & 0.215 & 0.397 & 5 \\
\hline \multirow{3}{*}{ Hanford town site } & 2003 & 0.422 & 0.422 & 0.085 & 0.337 & 0.507 & 2 \\
\hline & 2005 & 0.224 & 0.234 & 0.021 & 0.162 & 0.286 & 5 \\
\hline & 2007 & 0.343 & 0.279 & 0.076 & 0.23 & 0.646 & 5 \\
\hline Onsite & $2003-07$ & 0.314 & 0.277 & 0.022 & 0.646 & 0.162 & 30 \\
\hline Moses Lake & 2007 & 0.146 & 0.139 & 0.007 & 0.132 & 0.167 & 5 \\
\hline \multirow{2}{*}{ Priest Rapids pool } & 2003 & 0.428 & 0.428 & 0.066 & 0.362 & 0.495 & 2 \\
\hline & 2005 & 0.178 & 0.176 & 0.004 & 0.169 & 0.194 & 5 \\
\hline Offsite & $2003-07$ & 0.207 & 0.172 & 0.032 & 0.495 & 0.132 & 12 \\
\hline \multicolumn{8}{|c|}{ Copper } \\
\hline \multirow{3}{*}{100 Areas } & 2003 & 52.762 & 37 & 14.19 & 19.7 & 125 & 8 \\
\hline & 2005 & 53.76 & 59 & 7.147 & 26.3 & 65.3 & 5 \\
\hline & 2007 & 33.86 & 35.7 & 4.331 & 17.8 & 44.1 & 5 \\
\hline \multirow{3}{*}{ Hanford town site } & 2003 & 28.7 & 28.7 & 6.8 & 21.9 & 35.5 & 2 \\
\hline & 2005 & 59.34 & 58 & 9.828 & 25.9 & 85.8 & 5 \\
\hline & 2007 & 42.86 & 43.9 & 1.664 & 37.8 & 47 & 5 \\
\hline Onsite & $2003-07$ & 47.62 & 44 & 4.5 & 125 & 17.8 & 30 \\
\hline Moses Lake & 2007 & 28.008 & 28.4 & 8.715 & 9.74 & 59.1 & 5 \\
\hline \multirow{2}{*}{ Priest Rapids pool } & 2003 & 55.18 & 55.18 & 6.08 & 49.1 & 61.26 & 2 \\
\hline & 2005 & 19.5 & 18.5 & 2.182 & 13.2 & 26.7 & 5 \\
\hline Offsite & $2003-07$ & 28.992 & 23.7 & 5.16 & 61.26 & 9.74 & 12 \\
\hline \multicolumn{8}{|c|}{ Mercury } \\
\hline \multirow{3}{*}{100 Areas } & 2003 & 0.071 & 0.07 & 0.016 & 0.019 & 0.157 & 8 \\
\hline & 2005 & 0.052 & 0.032 & 0.015 & 0.027 & 0.104 & 5 \\
\hline & 2007 & 0.044 & 0.042 & 0.003 & 0.036 & 0.056 & 5 \\
\hline \multirow{3}{*}{ Hanford town site } & 2003 & 0.03 & 0.03 & 0.007 & 0.023 & 0.037 & 2 \\
\hline & 2005 & 0.063 & 0.061 & 0.007 & 0.04 & 0.082 & 5 \\
\hline & 2007 & 0.044 & 0.041 & 0.004 & 0.034 & 0.057 & 5 \\
\hline Onsite & $2003-07$ & 0.055 & 0.042 & 0.005 & 0.157 & 0.019 & 30 \\
\hline Moses Lake & 2007 & 0.037 & 0.041 & 0.004 & 0.024 & 0.043 & 5 \\
\hline \multirow{2}{*}{ Priest Rapids pool } & 2003 & 0.031 & 0.031 & 0.003 & 0.028 & 0.034 & 2 \\
\hline & 2005 & 0.021 & 0.021 & 0.001 & 0.019 & 0.025 & 5 \\
\hline Offsite & 2003-07 & 0.029 & 0.026 & 0.003 & 0.043 & 0.019 & 12 \\
\hline
\end{tabular}


Table A.2. (contd)

\begin{tabular}{|c|c|c|c|c|c|c|c|}
\hline Location & \multicolumn{7}{|c|}{ Standard } \\
\hline \multicolumn{8}{|c|}{ Manganese } \\
\hline \multirow{3}{*}{100 Areas } & 2003 & 12.08 & 11.4 & 1.139 & 8.07 & 16.4 & 8 \\
\hline & 2005 & 9.412 & 9.87 & 1.137 & 6.3 & 13 & 5 \\
\hline & 2007 & 7.148 & 6.59 & 0.718 & 6.15 & 10 & 5 \\
\hline \multirow{3}{*}{ Hanford town site } & 2003 & 11.48 & 11.48 & 1.62 & 9.86 & 13.1 & 2 \\
\hline & 2005 & 10.934 & 9.69 & 1.669 & 7.2 & 17.1 & 5 \\
\hline & 2007 & 10.524 & 9.63 & 0.773 & 9.08 & 12.5 & 5 \\
\hline Onsite & 2003-07 & 10.323 & 9.865 & 0.553 & 17.1 & 6.15 & 30 \\
\hline Moses Lake & 2007 & 11.262 & 12 & 0.921 & 8.87 & 13.6 & 5 \\
\hline \multirow{2}{*}{ Priest Rapids pool } & 2003 & 10.405 & 10.405 & 0.585 & 9.82 & 10.99 & 2 \\
\hline & 2005 & 8.644 & 8.3 & 0.418 & 7.95 & 10.25 & 5 \\
\hline Offsite & 2003-07 & 10.028 & 9.579 & 0.541 & 13.6 & 7.95 & 12 \\
\hline \multicolumn{8}{|c|}{ Lead } \\
\hline \multirow{3}{*}{100 Areas } & 2003 & 0.141 & 0.121 & 0.046 & 0.036 & 0.445 & 8 \\
\hline & 2005 & 0.263 & 0.129 & 0.133 & 0.041 & 0.743 & 5 \\
\hline & 2007 & 0.31 & 0.094 & 0.209 & 0.049 & 1.14 & 5 \\
\hline \multirow{3}{*}{ Hanford town site } & 2003 & 0.075 & 0.075 & 0.029 & 0.046 & 0.105 & 2 \\
\hline & 2005 & 0.134 & 0.069 & 0.053 & 0.05 & 0.328 & 5 \\
\hline & 2007 & 0.097 & 0.066 & 0.035 & 0.038 & 0.226 & 5 \\
\hline Onsite & 2003-07 & 0.176 & 0.099 & 0.043 & 1.14 & 0.036 & 30 \\
\hline Moses Lake & 2007 & 0.071 & 0.078 & 0.018 & 0.022 & 0.123 & 5 \\
\hline \multirow{2}{*}{ Priest Rapids pool } & 2003 & 0.047 & 0.047 & 0.014 & 0.034 & 0.061 & 2 \\
\hline & 2005 & 0.087 & 0.065 & 0.032 & $0.03^{(a)}$ & 0.207 & 5 \\
\hline \multirow[t]{2}{*}{ Offsite } & 2003-07 & 0.074 & 0.063 & 0.015 & 0.207 & 0.022 & 12 \\
\hline & & & Seleniu & & & & \\
\hline \multirow{3}{*}{100 Areas } & 2003 & 3.863 & 3.75 & 0.317 & 2.66 & 5.5 & 8 \\
\hline & 2005 & 3.538 & 3.57 & 0.229 & 2.77 & 4.2 & 5 \\
\hline & 2007 & 5.114 & 4.87 & 0.452 & 3.97 & 6.41 & 5 \\
\hline \multirow{3}{*}{ Hanford town site } & 2003 & 2.625 & 2.625 & 0.545 & 2.08 & 3.17 & 2 \\
\hline & 2005 & 4.982 & 4.03 & 0.82 & 3.44 & 7.27 & 5 \\
\hline & 2007 & 6.736 & 6.79 & 0.115 & 6.33 & 6.97 & 5 \\
\hline Onsite & 2003-07 & 4.6 & 4.115 & 0.279 & 7.27 & 2.08 & 30 \\
\hline Moses Lake & 2007 & 1.279 & 1.14 & 0.225 & 0.893 & 2.11 & 5 \\
\hline \multirow{2}{*}{ Priest Rapids pool } & 2003 & 2.338 & 2.338 & 1.088 & 1.25 & 3.425 & 2 \\
\hline & 2005 & 2.107 & 2.18 & 0.217 & 1.55 & 2.75 & 5 \\
\hline Offsite & 2003-07 & 1.8 & 1.63 & 0.226 & 3.425 & 0.893 & 12 \\
\hline
\end{tabular}


Table A.2. (contd)

\begin{tabular}{|c|c|c|c|c|c|c|c|}
\hline Location & Year & Mean & Median & $\begin{array}{l}\text { Standard } \\
\text { Error }\end{array}$ & Minimum & Maximum & Count \\
\hline \multicolumn{8}{|c|}{ Thallium } \\
\hline \multirow{3}{*}{100 Areas } & 2003 & 0.057 & 0.058 & 0.005 & 0.039 & 0.082 & 8 \\
\hline & 2005 & 0.05 & 0.04 & 0.012 & 0.032 & 0.099 & 5 \\
\hline & 2007 & 0.051 & 0.044 & 0.01 & 0.024 & 0.08 & 5 \\
\hline \multirow{3}{*}{ Hanford town site } & 2003 & 0.032 & 0.032 & $4.50 \mathrm{E}-04$ & 0.032 & 0.033 & 2 \\
\hline & 2005 & 0.046 & 0.05 & 0.004 & 0.033 & 0.054 & 5 \\
\hline & 2007 & 0.05 & 0.048 & 0.005 & 0.036 & 0.063 & 5 \\
\hline Onsite & 2003-07 & 0.05 & 0.048 & 0.003 & 0.099 & 0.024 & 30 \\
\hline Moses Lake & 2007 & 0.018 & 0.012 & 0.005 & 0.01 & 0.039 & 5 \\
\hline \multirow{2}{*}{ Priest Rapids pool } & 2003 & 0.054 & 0.054 & 0.006 & 0.048 & 0.061 & 2 \\
\hline & 2005 & 0.005 & 0.004 & 0.001 & $0.004^{(\mathrm{a})}$ & 0.008 & 5 \\
\hline Offsite & 2003-07 & 0.019 & 0.01 & 0.006 & 0.061 & 0.004 & 12 \\
\hline \multicolumn{8}{|c|}{ Zinc } \\
\hline \multirow{3}{*}{100 Areas } & 2003 & 144 & 136 & 11.77 & 107 & 198 & 8 \\
\hline & 2005 & 152 & 146 & 7.35 & 134 & 178 & 5 \\
\hline & 2007 & 152 & 150 & 4.59 & 141 & 166 & 5 \\
\hline \multirow{3}{*}{ Hanford town site } & 2003 & 223 & 223 & 67.50 & 155 & 290 & 2 \\
\hline & 2005 & 142 & 145 & 11.46 & 111 & 176.5 & 5 \\
\hline & 2007 & 169 & 169 & 7.10 & 147 & 188 & 5 \\
\hline Onsite & 2003-07 & 156 & 148.5 & 6.246 & 290 & 107 & 30 \\
\hline Moses Lake & 2007 & 233 & 135 & 72.00 & 129 & 500 & 5 \\
\hline \multirow{2}{*}{ Priest Rapids pool } & 2003 & 140 & 140 & 29.00 & 111 & 169 & 2 \\
\hline & 2005 & 135 & 135 & 6.55 & 115 & 153 & 5 \\
\hline Offsite & 2003-07 & 176 & 135 & 31.809 & 500 & 111 & 12 \\
\hline
\end{tabular}

(a) Value shown is the lower limit of detection. Group I metals arsenic, lead, and thallium had some values where the analytical result was less than detection. 
Table A.3. Descriptive Statistics for Concentrations of Group II Metals in Canada Goose Liver Collected in 2003, 2005, and 2007 (not blank-corrected, $\mu \mathrm{g} / \mathrm{g}$ dry wt)

\begin{tabular}{|c|c|c|c|c|c|c|c|c|}
\hline Location & Year & $\mathrm{LADL}^{\text {(a) }}$ & Mean & Median & $\begin{array}{l}\text { Standard } \\
\text { Error }\end{array}$ & Minimum & Maximum & Count \\
\hline \multicolumn{9}{|c|}{ Antimony } \\
\hline \multirow{3}{*}{100 Areas } & 2003 & 0.019 & 0.022 & 0.019 & 0.0020 & 0.019 & 0.03 & 8 \\
\hline & 2005 & 0.01 & 0.01 & 0.01 & 0.0000 & 0.01 & 0.01 & 5 \\
\hline & 2007 & 0.02 & 0.02 & 0.02 & 0.0000 & 0.02 & 0.02 & 5 \\
\hline \multirow{3}{*}{$\begin{array}{l}\text { Hanford town site/ } \\
300 \text { Area }\end{array}$} & 2003 & 0.019 & 0.019 & 0.019 & 0.0000 & 0.019 & 0.019 & 2 \\
\hline & 2005 & 0.01 & 0.01 & 0.01 & 0.0002 & 0.01 & 0.011 & 5 \\
\hline & 2007 & 0.02 & 0.02 & 0.02 & 0.0000 & 0.02 & 0.02 & 5 \\
\hline Moses Lake & 2007 & 0.02 & 0.02 & 0.02 & 0.0000 & 0.02 & 0.02 & 5 \\
\hline \multirow{2}{*}{ Priest Rapids pool } & 2003 & 0.019 & 0.033 & 0.033 & 0.0140 & 0.019 & 0.047 & 2 \\
\hline & 2005 & 0.01 & 0.012 & 0.011 & 0.0010 & 0.01 & 0.014 & 5 \\
\hline \multicolumn{9}{|c|}{ Barium } \\
\hline 100 Areas & 2003 & 0.03 & 0.179 & 0.198 & 0.0330 & 0.104 & 0.282 & 5 \\
\hline Priest Rapids pool & 2003 & 0.03 & 0.086 & 0.086 & NA & 0.086 & 0.086 & 1 \\
\hline \multicolumn{9}{|c|}{ Beryllium } \\
\hline \multirow{3}{*}{100 Areas } & 2003 & 0.019 & 0.035 & 0.019 & 0.0100 & 0.019 & 0.08 & 8 \\
\hline & 2005 & 0.007 & 0.007 & 0.007 & 0.0000 & 0.007 & 0.007 & 5 \\
\hline & 2007 & 0.02 & 0.02 & 0.02 & 0.0000 & 0.02 & 0.02 & 5 \\
\hline \multirow{3}{*}{$\begin{array}{l}\text { Hanford town site/ } \\
300 \text { Area }\end{array}$} & 2003 & 0.019 & 0.027 & 0.027 & 0.0030 & 0.024 & 0.03 & 2 \\
\hline & 2005 & 0.007 & 0.007 & 0.007 & 0.0000 & 0.007 & 0.007 & 5 \\
\hline & 2007 & 0.02 & 0.02 & 0.02 & 0.0000 & 0.02 & 0.02 & 5 \\
\hline Moses Lake & 2007 & 0.01 & 0.01 & 0.01 & 0.0000 & 0.01 & 0.01 & 5 \\
\hline \multirow{2}{*}{ Priest Rapids pool } & 2003 & 0.019 & 0.019 & 0.019 & 0.0000 & 0.019 & 0.019 & 2 \\
\hline & 2005 & 0.007 & 0.008 & 0.007 & 0.0010 & 0.007 & 0.011 & 5 \\
\hline \multicolumn{9}{|c|}{ Nickel } \\
\hline \multirow{3}{*}{100 Areas } & 2003 & 0.045 & 0.079 & 0.047 & 0.0270 & 0.045 & 0.264 & 8 \\
\hline & 2005 & 0.05 & 0.05 & 0.05 & 0.0000 & 0.05 & 0.05 & 5 \\
\hline & 2007 & 0.04 & 0.044 & 0.04 & 0.0040 & 0.04 & 0.061 & 5 \\
\hline \multirow{3}{*}{$\begin{array}{l}\text { Hanford town site/ } \\
300 \text { Area }\end{array}$} & 2003 & 0.045 & 0.045 & 0.045 & 0.0000 & 0.045 & 0.045 & 2 \\
\hline & 2005 & 0.05 & 0.052 & 0.05 & 0.0020 & 0.05 & 0.06 & 5 \\
\hline & 2007 & 0.04 & 0.041 & 0.04 & 0.0010 & 0.04 & 0.043 & 5 \\
\hline Moses Lake & 2007 & 0.04 & 0.04 & 0.04 & 0.0000 & 0.04 & 0.04 & 5 \\
\hline \multirow{2}{*}{ Priest Rapids pool } & 2003 & 0.045 & 0.045 & 0.045 & 0.0000 & 0.045 & 0.045 & 2 \\
\hline & 2005 & 0.05 & 0.05 & 0.05 & 0.0000 & 0.05 & 0.05 & 5 \\
\hline
\end{tabular}


Table A.3. (contd)

\begin{tabular}{|c|c|c|c|c|c|c|c|c|}
\hline Location & Year & $\mathrm{LADL}^{(\mathrm{a})}$ & Mean & Median & $\begin{array}{l}\text { Standard } \\
\text { Error }\end{array}$ & Minimum & Maximum & Count \\
\hline \multicolumn{9}{|c|}{ Silver } \\
\hline \multirow{3}{*}{100 Areas } & 2003 & 0.045 & 0.046 & 0.045 & 0.0010 & 0.045 & 0.05 & 8 \\
\hline & 2005 & 0.003 & 0.028 & 0.031 & 0.0060 & 0.004 & 0.042 & 5 \\
\hline & 2007 & 0.01 & 0.011 & 0.01 & 0.0010 & 0.01 & 0.014 & 5 \\
\hline \multirow{3}{*}{$\begin{array}{l}\text { Hanford town site/ } \\
300 \text { Area }\end{array}$} & 2003 & 0.045 & 0.045 & 0.045 & 0.0000 & 0.045 & 0.045 & 2 \\
\hline & 2005 & 0.003 & 0.043 & 0.04 & 0.0130 & 0.005 & 0.085 & 5 \\
\hline & 2007 & 0.01 & 0.012 & 0.01 & 0.0020 & 0.01 & 0.02 & 5 \\
\hline Moses Lake & 2007 & 0.01 & 0.022 & 0.02 & 0.0060 & 0.01 & 0.039 & 5 \\
\hline \multirow{2}{*}{ Priest Rapids pool } & 2003 & 0.045 & 0.045 & 0.045 & 0.0000 & 0.045 & 0.045 & 2 \\
\hline & 2005 & 0.003 & 0.012 & 0.012 & 0.0030 & 0.004 & 0.023 & 5 \\
\hline \multicolumn{9}{|c|}{ Thorium } \\
\hline \multirow{3}{*}{100 Areas } & 2003 & 0.021 & 0.021 & 0.021 & 0.0000 & 0.021 & 0.021 & 8 \\
\hline & 2005 & 0.01 & 0.01 & 0.01 & 0.0002 & 0.01 & 0.011 & 5 \\
\hline & 2007 & 0.03 & 0.013 & 0.013 & 0.0020 & 0.006 & 0.019 & 5 \\
\hline \multirow{3}{*}{$\begin{array}{l}\text { Hanford town site/ } \\
300 \text { Area }\end{array}$} & 2003 & 0.021 & 0.021 & 0.021 & 0.0000 & 0.021 & 0.021 & 2 \\
\hline & 2005 & 0.01 & 0.01 & 0.01 & 0.0000 & 0.01 & 0.01 & 5 \\
\hline & 2007 & 0.03 & 0.006 & 0.004 & 0.0020 & 0.003 & 0.013 & 5 \\
\hline Moses Lake & 2007 & 0.01 & 0.015 & 0.01 & 0.0050 & 0.01 & 0.033 & 5 \\
\hline \multirow{2}{*}{ Priest Rapids pool } & 2003 & 0.021 & 0.043 & 0.043 & 0.0210 & 0.021 & 0.064 & 2 \\
\hline & 2005 & 0.01 & 0.073 & 0.073 & 0.0080 & 0.047 & 0.096 & 5 \\
\hline \multicolumn{9}{|c|}{ Uranium } \\
\hline \multirow{3}{*}{100 Areas } & 2003 & 0.031 & 0.031 & 0.031 & 0.0000 & 0.031 & 0.031 & 8 \\
\hline & 2005 & 0.002 & 0.002 & 0.002 & 0.0002 & 0.002 & 0.002 & 5 \\
\hline & 2007 & 0.002 & 0.002 & 0.002 & 0.0002 & 0.002 & 0.003 & 5 \\
\hline \multirow{3}{*}{$\begin{array}{l}\text { Hanford town site/ } \\
300 \text { Area }\end{array}$} & 2003 & 0.031 & 0.031 & 0.031 & 0.0000 & 0.031 & 0.031 & 2 \\
\hline & 2005 & 0.002 & 0.003 & 0.003 & 0.0004 & 0.002 & 0.004 & 5 \\
\hline & 2007 & 0.002 & 0.002 & 0.002 & 0.0001 & 0.002 & 0.002 & 5 \\
\hline Moses Lake & 2007 & 0.002 & 0.002 & 0.002 & 0.0000 & 0.002 & 0.002 & 5 \\
\hline \multirow{2}{*}{ Priest Rapids pool } & 2003 & 0.031 & 0.031 & 0.031 & 0.0000 & 0.031 & 0.031 & 2 \\
\hline & 2005 & 0.002 & 0.004 & 0.004 & 0.0010 & 0.001 & 0.006 & 5 \\
\hline
\end{tabular}


Appendix B

Literature Evaluation of Group I and II Metal Contaminants in Canada Goose Liver 


\section{Appendix B}

\section{Literature Evaluation of Group I and II Metal Contaminants in Canada Goose Liver}

\section{B.1 Literature Comparisons of Group I Metals in Goose Liver}

The liver was selected for analysis because it is the organ with the greatest likelihood of reflecting accumulation of a broad spectrum of metals. To ascertain if the metal concentrations observed in goose livers represent elevated risk, the concentrations of metals in goose liver were compared to benchmark values from two other databases for waterfowl. Toxicity benchmarks have been compiled in the Environmental Residue-Effects Database (ERED; USACE/EPA 2005). This database associates toxicity and physiological responses with measured tissue residues and consists of both no-observed effect concentrations and effect concentrations. Results in ERED were reported on a wet-weight basis and, for comparison to our data, were converted to dry weight using a conversion factor of 3.0 wet to dry weight. The ERED database provided toxicity benchmarks for cadmium, lead, mercury, and selenium.

The U.S. Geological Survey Contaminants Exposure and Effects Database (Rattner et al. 2006) was also reviewed to collect additional information on the levels of metals reported in other species of waterfowl collected in North America. In most cases, the potential for exposure to elevated levels of metals to these fowl is unknown and the summarized data simply provide a point of reference. In some cases (i.e., lead), metal concentrations were associated with the presence of lead shot in the gizzard, or wintering waterfowl were collected from areas known to have received anthropogenic contamination. Also, where liver concentrations were reported in wet weight, they were converted to dry weight by multiplying by 3 .

Data were not available for Canada geese in either of these databases, so our assessment used relationships established for other waterfowl including lesser snow geese (Chen [formerly Anser] caerulescens caerlescens; Hui et al. 1998), the black duck (Anas rubripes), canvasback (Aythya valisineria), greater scaup (Aythya marila), and redhead (Aythya americana). Data for these last four species were obtained primarily from Rattner et al. (2006). Data in these reports consisted of means, medians, associated estimates of uncertainty (i.e., standard deviation, standard error), raw data, or maximums. This information is summarized in Table B.1.

Very few studies that report ecotoxicological benchmarks or biomarker concentrations can be directly linked to concentrations of metals in liver tissue of waterfowl. Results that were found were included in Figure 4.8 and have been summarized here in Table B.2. 
Table B.1. Hepatic Concentrations of Group I Metals in Waterfowl in Articles Reviewed by Rattner et al. (2006) and Other Sources

\begin{tabular}{|c|c|c|c|}
\hline Species & Range of Means (2 SEM) ${ }^{(\mathrm{a})}$ & Range or Single Values & Study \\
\hline \multicolumn{4}{|c|}{ Aluminum } \\
\hline Canada goose & $2.4(0.74)-11.4(12.3)$ & $1.29-54.2$ & $\begin{array}{l}\text { This study (data summarized } \\
\text { from Appendix A). }\end{array}$ \\
\hline Snow goose & & $<3.35$ & Hui et al. (1998) \\
\hline \multicolumn{4}{|c|}{ Arsenic } \\
\hline Canada goose & $0.15(0.054)-0.37(0.332)$ & $0.07^{(\mathrm{b})}-0.746$ & $\begin{array}{l}\text { This study (data summarized } \\
\text { from Appendix A). }\end{array}$ \\
\hline Canvasback & 0.25 & & Miles and Ohlendorf(1993) \\
\hline Greater scaup & 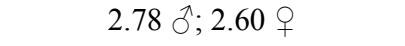 & & Barclay et al. (1995) \\
\hline Greater scaup & $0.29-2.17$ & & Cohen et al. (2000) \\
\hline Redhead & 0.59 & $(<0.30-2.70)$ & Michot et al. (1994) \\
\hline Snow goose & & $<0.17$ & \\
\hline \multicolumn{4}{|c|}{ Cadmium } \\
\hline Canada goose & $2.15(2.07)-8.99$ (13.2) & $0.22-15.6$ & $\begin{array}{l}\text { This study (data summarized } \\
\text { from Appendix A). }\end{array}$ \\
\hline \multirow{5}{*}{ Black duck } & 1.16 & $<0.10-11.75$ & DiGiulio and Scanlon (1984) \\
\hline & & $\begin{array}{c}0.254-0.385 \text { (wet wt) } \\
{[0.76-1.16 \text { dry wt }]}\end{array}$ & Gochfeld and Burger (1982) \\
\hline & 0.518 wet wt [ 1.56 dry wt] & & Burger and Gochfeld (1985) \\
\hline & 0.333 wet wt $[1.00$ dry wt $]$ & & \\
\hline & 0.565 wet wt [1.70 dry wt] $\hat{\partial}$ & & Gochfeld and Burger (1982) \\
\hline \multirow{4}{*}{ Canvasback } & 0.59 & & White et al. (1979) \\
\hline & 3.1 & & DiGiulio and Scanlon (1984) \\
\hline & $0.43-0.66$ & & Custer and Hohman (1994) \\
\hline & 0.56 & & Miles and Ohlendorf(1993) \\
\hline \multirow{6}{*}{ Greater scaup } & & $\begin{array}{c}<\text { Det. }-2.0 \text { wet wt } \\
{[<\text { Det. }-6.0 \text { dry wt }]} \\
0.10-3.16\end{array}$ & $\begin{array}{l}\text { Baker et al. (1976) } \\
\text { DiGiulio and Scanlon (1984) }\end{array}$ \\
\hline & 0.95 wet wt [ 2.85 dry wt] & & Burger and Gochfeld (1985) \\
\hline & 2.91 & & Barclay and Zingo (1993) \\
\hline & $3(\mathrm{Geo}) ; 4(\mathrm{Geo})^{(\mathrm{c})}$ & $1-17 \mathrm{R} ; 1-7 \mathrm{C}^{(\mathrm{d})}$ & Hoffman et al. (1998) \\
\hline & 1.68 ○ं; 4.24 ㅇ & & Barclay et al. (1995) \\
\hline & $0.65-3.07$ & & Cohen et al. (2000) \\
\hline Redhead & 0.91 & $<0.80-5.41$ & Michot et al. (1994) \\
\hline Snow goose & $1.9\left(1.00 \mathrm{SD}^{(\mathrm{b})}\right)-2.3(1.02 \mathrm{SD})$ & & Hui et al. (1998) \\
\hline \multicolumn{4}{|c|}{ Chromium } \\
\hline \multirow[t]{2}{*}{ Canada goose } & $0.18(0.008)-0.48(0.24)$ & $0.16-0.60$ & $\begin{array}{l}\text { This study (data summarized } \\
\text { from Appendix A). }\end{array}$ \\
\hline & 2.05 wet wt $[6.05$ dry wt $]$ & & Burger and Gochfeld (1985) \\
\hline \multirow[t]{2}{*}{ Black duck } & 2.048 wet wt $[6.14$ dry wt $] \stackrel{+}{+}$ & & \\
\hline & 2.053 wet wt $[6.16$ dry wt $] \hat{\partial}$ & & Gochfeld and Burger (1987) \\
\hline \multirow{2}{*}{ Canvasback } & 0.02 wet wt $[0.06$ dry wt $]$ & & White et al. (1979) \\
\hline & $<$ Det. & & Miles and Ohlendorf(1993) \\
\hline \multirow[t]{4}{*}{ Greater scaup } & 0.58 wet wt $[1.76$ dry wt $]$ & & Burger and Gochfeld (1985) \\
\hline & 1.02 & & Barclay and Zingo (1993) \\
\hline & 1.68 ふૈ; 1.70 q & & Barclay et al. (1995) \\
\hline & $0.65-3.07$ & & Cohen et al. (2000) \\
\hline Snow goose & $1.03(0.51 \mathrm{SD})-1.3(0.42)$ & & Hui et al. (1998) \\
\hline
\end{tabular}


Table B.1. (contd)

\begin{tabular}{|c|c|c|c|}
\hline Species & Range of Means (2 SEM) ${ }^{(\mathrm{a})}$ & Range or Single Values & Study \\
\hline \multicolumn{4}{|c|}{ Copper } \\
\hline Canada goose & $19.6(4.4)-59.5(19.8)$ & $13.2-125$ & $\begin{array}{l}\text { This study (data summarized } \\
\text { from Appendix A). }\end{array}$ \\
\hline \multirow{3}{*}{ Black duck } & 34.9 & $1.5-235.4$ & DiGiulio and Scanlon (1984) \\
\hline & 8.51 wet wt [25.5 dry wt] & & Burger and Gochfeld (1985) \\
\hline & 5.72 wet wt [ 17.1 dry wt] & & Gochfeld and Puroer (1087) \\
\hline \multirow{4}{*}{ Canvasback } & 0.59 wet wt $[1.77$ dry wt] & & White et al. (1979) \\
\hline & 113.7 & & DiGiulio and Scanlon (1984) \\
\hline & $85-187$ & & Custer and Hohman (1994) \\
\hline & 99.1 & & Miles and Ohlendorf (1993) \\
\hline \multirow{9}{*}{ Greater scaup } & 17.2 wet wt $[51.6$ dry wt $](\mathrm{P})^{(\mathrm{c})}$ & & \\
\hline & 19.6 wet wt [58.8 dry wt] (R) & & Vermeer and Peakall (1979) \\
\hline & & $6.90-117$ & DiGiulio and Scanlon (1984) \\
\hline & 48.1 wet wt [144 dry wt] & & Burger and Gochfeld (1985) \\
\hline & 96.8 & $28.0-159$ & Ohlendorf et al. (1986) \\
\hline & 101 (Geo Bay) $^{(\mathrm{d})}$ & & \\
\hline & 88.6 (Geo Coastal) & & Hothem et al. (1998) \\
\hline & 73.1 ふै; 50.9 우 & & Barclay et al. (1995) \\
\hline & $21.3-82.1$ & & Cohen et al. (2000) \\
\hline Redhead & 153 & $(8-1030)$ & Michot et al. (1994) \\
\hline Snow goose & $46.7-78$ & $19.5-626$ & Hui et al. (1998) \\
\hline \multicolumn{4}{|c|}{ Mercury } \\
\hline Canada goose & $0.021(0.002)-0.071(0.032)$ & $0.019-0.157$ & $\begin{array}{l}\text { This study (data summarized } \\
\text { from Appendix A). }\end{array}$ \\
\hline \multirow{4}{*}{ Black duck } & & $0.03-0.284$ & Baker et al. (1976) \\
\hline & 0.525 wet wt [ 1.58 dry wt $]$ & & Burger and Gochfeld (1985) \\
\hline & 0.588 wet wt [ 1.76 dry wt] $\stackrel{\circ}{+}$ & & \\
\hline & 0.478 wet wt [ 1.43 dry wt $] \widehat{\partial}$ & & Gochfeld and Burger (1987) \\
\hline Redhead & 0.06 & $0.02-1.53$ & Michot et al. (1994) \\
\hline \multirow{4}{*}{ Canvasback } & 0.24 wet wt [0.72 dry wt] & & White et al. (1979) \\
\hline & 0.047 & & Baker et al. (1976) \\
\hline & $0.18-3.2$ & & Custer and Hohman (1994) \\
\hline & 3.09 & & Miles and Ohlendorf (1993) \\
\hline \multirow{9}{*}{ Greater scaup } & & $1.9-9.9$ & Dale et al. (1973) \\
\hline & & $\begin{array}{l}<\text { Det. }-0.02 \text { wet wt } \\
{[<\text { Det. }-0.06 \text { dry wt }]}\end{array}$ & Baker et al. (1976) \\
\hline & $\begin{array}{c}0.25 \text { wet wt }[0.75 \text { dry wt }](\mathrm{P})^{(\mathrm{b})} \\
0.26 \text { wet wt }[0.78 \text { dry wt }](\mathrm{R})\end{array}$ & & Vermeer and Peakall (1979) \\
\hline & 0.74 & & Burger and Gochfeld (1985) \\
\hline & 10.6 & $2.30-20.0$ & Ohlendorf et al. (1986) \\
\hline & 2.37 (Geo Bay) $^{\text {(c) }}$ & & \\
\hline & $19(\mathrm{R}) ; 6(\mathrm{Geo} C)^{(\mathrm{d})}$ & $5-66(\mathrm{R}) ; 3-11(\mathrm{C})^{(\mathrm{d})}$ & Hoffman et al. (1998) \\
\hline & 2.18 万; 2.43 우 & & Barclay et al. (1995) \\
\hline & $0.87-3.80$ & & Cohen et al. (2000) \\
\hline
\end{tabular}


Table B.1. (contd)

\begin{tabular}{|c|c|c|c|}
\hline Species & Range of Means (2 SEM) $)^{(\mathrm{a})}$ & Range or Single Values & Study \\
\hline \multicolumn{4}{|c|}{ Manganese } \\
\hline \multirow[t]{2}{*}{ Canada goose } & $8.69(0.93)-12.1(2.3)$ & $6.3-17.3$ & $\begin{array}{l}\text { This study (data summarized } \\
\text { from Appendix A). }\end{array}$ \\
\hline & 1.85 wet wt [5.55 dry wt] & & Burger and Gochfeld (1985) \\
\hline \multirow[t]{2}{*}{ Black duck } & $\begin{array}{l}1.27 \text { wet wt }[3.81 \text { dry wt }] \text { 웅 } \\
2.28 \text { wet wt }[6.84 \text { dry wt }\end{array}$ & & Gochfeld and Burger (1987) \\
\hline & $11.7-12.4$ & & Custer and Hohman (1994) \\
\hline Greater scaup & 4.30 wet wt [12.9 dry wt] & & Burger and Gochfeld (1985) \\
\hline Redhead & 7.27 & $3.88-11.50$ & Michot et al. (1994) \\
\hline Snow goose & $9.9(2.5 \mathrm{SD})-10.3(2.8 \mathrm{SD})^{(\mathrm{e})}$ & & Hui et al. (1998) \\
\hline \multicolumn{4}{|c|}{ Lead } \\
\hline \multirow[t]{3}{*}{ Canada goose } & $0.047(0.028)-0.26(0.27)$ & $0.03^{(\mathrm{b})}-0.743$ & $\begin{array}{l}\text { This study (data summarized } \\
\text { from Appendix A). }\end{array}$ \\
\hline & & $<$ Det. -6.96 & Baker et al. (1976) \\
\hline & $12.4(<0.5-302.4)$ & $<0.5-302.4$ & DiGiulio and Scanlon (1984) \\
\hline \multirow{4}{*}{ Black duck } & 36.8 (lead shot in gizzard) & & \\
\hline & 11.4 (no lead shot in gizzard) & & Scanlon et al. (1980) \\
\hline & 0.601 wet wt [1.80 dry wt] & & Burger and Gochfeld (1985) \\
\hline & 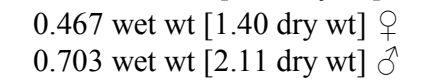 & & Gochfeld and Burger (1987) \\
\hline \multirow[t]{2}{*}{ Includes mallards } & & $<1-21$ & Calle et al. (1982) \\
\hline & 0.5 wet wt $[1.5$ dry wt $]$ & & Bagley and Locke (1967) \\
\hline \multirow{7}{*}{ Canvasback } & 0.25 wet wt $[0.75$ dry wt $](1973)$ & & \\
\hline & 0.14 wet wt [0.42 dry wt] (1975) & & \\
\hline & $0.19[0.57$ dry wt $]$ wet wt (1976) & & White et al. (1979) \\
\hline & 12.6 wet wt $[37.8$ dry wt] & & Baker et al. (1976) \\
\hline & 3.8 & & DiGiulio and Scanlon (1984) \\
\hline & 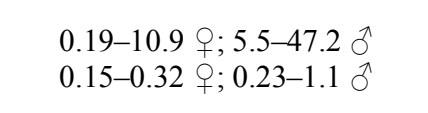 & & $\begin{array}{l}\text { Custer and Hohman (1994) } \\
\text { Values represent separated study } \\
\text { groups. }\end{array}$ \\
\hline & 0.43 & & Miles and Ohlendorf(1993) \\
\hline \multirow{11}{*}{ Greater scaup } & & $\begin{array}{l}<\text { Det. }-10.0 \text { wet wt } \\
{[<\text { Det. }-30 \text { dry wt }]}\end{array}$ & Baker et al. (1976) \\
\hline & 1.33 wet wt $\left[4.0\right.$ dry wt $(\mathrm{P})^{(\mathrm{c})}$ & & \\
\hline & 0.35 wet wt [1.05 dry wt] (R) & & Vermeer and Peakall (1979) \\
\hline & & $5.20-21.5$ & DiGiulio and Scanlon (1984) \\
\hline & & 1.5 (lead shot in gizzard) & Scanlon et al. (1980) \\
\hline & 0.49 wet wt [ 1.47 dry wt] & & Burger and Gochfeld (1985) \\
\hline & 0.71 & $0.34-3.10$ & Ohlendorf et al. (1986) \\
\hline & 0.81 & & Barclay and Zingo (1993) \\
\hline & 1.75 ふ;; 1.60 우 & & Barclay et al. (1995) \\
\hline & $0.56-1.92$ & & Cohen et al. (2000) \\
\hline & $0.77(0.39 \mathrm{SD})-50.2(185 \mathrm{SD})^{(\mathrm{d})}$ & & Hui et al. (1998) \\
\hline
\end{tabular}


Table B.1. (contd)

\begin{tabular}{|c|c|c|c|}
\hline Species & Range of Means (2 SEM) ${ }^{(\mathrm{a})}$ & Range or Single Values & Study \\
\hline \multicolumn{4}{|c|}{ Selenium } \\
\hline Canada goose & $2.1(0.46)-5.0(1.7)$ & $1.25-7.45$ & $\begin{array}{l}\text { This study (data summarized } \\
\text { from Appendix A). }\end{array}$ \\
\hline \multirow{3}{*}{ Canvasback } & $3.6-4.0$ & & Custer and Hohman (1994) \\
\hline & 13.2 & & Miles and Ohlendorf (1993) \\
\hline & 19.3 & $6.70-31.0$ & Ohlendorf et al. (1986) \\
\hline \multirow{5}{*}{ Greater scaup } & $\begin{array}{l}20.7(\text { Geo Bay })^{(\mathrm{b})} \\
7.01 \text { (Geo Coastal) }^{2}\end{array}$ & & Hothem et al. (1998) \\
\hline & $13(\text { Geo R })^{(\mathrm{c})}$ & $7-23(\mathrm{R})^{(\mathrm{c})}$ & \\
\hline & $67($ Geo C) & $21-140(\mathrm{C})$ & Hoffman et al. (1998) \\
\hline & 15.5 ऽ; 14.4 q & & Barclay et al. (1995) \\
\hline & $3.38-23.4$ & & Cohen et al. (2000) \\
\hline Redhead & 3.19 & $(1.56-5.85)$ & Michot et al. (1994) \\
\hline Snow goose & $4.4(1.0 \mathrm{SD})-4.2(0.84 \mathrm{SD})^{(\mathrm{d})}$ & & Hui et al. (1998) \\
\hline \multicolumn{4}{|c|}{ Thallium } \\
\hline Canada goose & $0.005(0.002)-0.057(0.010)$ & $0.004^{(\mathrm{e})}-0.099$ & $\begin{array}{l}\text { This study (data summarized } \\
\text { from Appendix A). }\end{array}$ \\
\hline \multicolumn{4}{|r|}{ 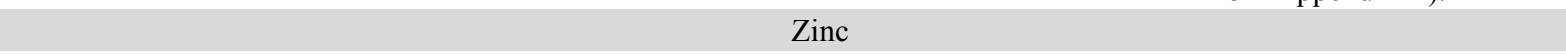 } \\
\hline Canada goose & $135(13.8)-223(135)$ & $107-290$ & $\begin{array}{l}\text { This study (data summarized } \\
\text { from Appendix A). }\end{array}$ \\
\hline \multirow{4}{*}{ Black duck } & 136 & $29-495$ & DiGiulio and Scanlon (1984) \\
\hline & 40.5 wet wt [121.5 dry wt] & & Burger and Gochfeld (1985) \\
\hline & 17.96 wet wt $[53.9$ dry wt $]$ 우 & & \\
\hline & 50.0 wet wt [150 dry wt $]$ & & Gochfeld and Burger (1987) \\
\hline \multirow{4}{*}{ Canvasback } & 41 wet wt [123 dry wt] & & White et al. (1979) \\
\hline & 170 & & DiGiulio and Scanlon (1984) \\
\hline & $128-137$ & & Custer and Hohman (1994) \\
\hline & 160 & & Miles and Ohlendorf (1993) \\
\hline \multirow{9}{*}{ Greater scaup } & 41.6 wet wt $[125$ dry wt $](P)^{(f)}$ & & \\
\hline & 40.2 wet wt [121 dry wt] (R) & & Vermeer and Peakall (1979) \\
\hline & & $42.0-176$ & DiGiulio and Scanlon (1984) \\
\hline & 59.8 wet wt [179 dry wt] & & Burger and Gochfeld (1985) \\
\hline & 151 & $100-200$ & Ohlendorf et al. (1986) \\
\hline & $158{\text { (Geo Bay })^{(\mathrm{b})}}$ & & \\
\hline & 171 (Geo Coastal) & & Hothem et al. (1998) \\
\hline & 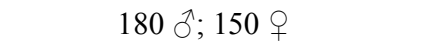 & & Barclay et al. (1995) \\
\hline & $57.9-167$ & & Cohen et al. (2000) \\
\hline Redhead & 122 & $(68-337)$ & Michot et al. (1994) \\
\hline Snow goose & $89.2-133$ & $55.6-413.8$ & Hui et al. (1998) \\
\hline \multicolumn{4}{|c|}{ (a) $2 \mathrm{SEM}=2$ standard errors of the mean. } \\
\hline \multicolumn{4}{|c|}{ (b) Geo $=$ geometric mean. } \\
\hline \multicolumn{4}{|c|}{ (c) $\mathrm{R}=$ reference area; $\mathrm{C}=$ contaminated area. } \\
\hline \multicolumn{4}{|c|}{ (d) $\mathrm{SD}=$ standard deviation. } \\
\hline \multicolumn{4}{|c|}{ is the analytical lower lin } \\
\hline (f) $\mathrm{P}=$ pollut & $=$ reference area & & \\
\hline
\end{tabular}


Table B.2. Summary of Feeding Studies with Waterfowl Indicating Liver Concentrations of Metals and Associated Effects on the Birds

\begin{tabular}{|c|c|c|c|c|c|}
\hline \multirow[b]{2}{*}{ Species } & \multicolumn{2}{|c|}{$\begin{array}{l}\text { Liver }(\mu \mathrm{g} / \mathrm{g} \text {, wet wt.) } \\
\text { Dry wt. in [brackets] }\end{array}$} & \multirow[b]{2}{*}{ Effects } & \multirow[b]{2}{*}{ Study Comments } & \multirow[b]{2}{*}{ Reference } \\
\hline & Control & Test & & & \\
\hline \multicolumn{6}{|c|}{ Cadmium } \\
\hline \multirow[t]{2}{*}{ Black duck } & $\begin{array}{c}0.6 \\
{[1.8]}\end{array}$ & $\begin{array}{c}10.5 \\
{[31.5]}\end{array}$ & $\begin{array}{l}\text { Locomotion increased when } \\
\text { ducks were on diet; no effect } \\
\text { on body mass. }\end{array}$ & $\begin{array}{l}\text { Dietary exposure } 4 \mu \mathrm{g} / \mathrm{g} \\
\text { cadmium in diet, } 2 \text {-year } \\
\text { study with two feeding } \\
\text { periods. }\end{array}$ & $\begin{array}{l}\text { Silver and } \\
\text { Nudds (1995) }\end{array}$ \\
\hline & $\begin{array}{c}0.6 \\
{[1.8]}\end{array}$ & $\begin{array}{c}33 \\
{[99]}\end{array}$ & $\begin{array}{l}\text { Locomotion increased when } \\
\text { ducks were on diet; no effect } \\
\text { on body mass. }\end{array}$ & $\begin{array}{l}\text { Dietary exposure } 4 \mu \mathrm{g} / \mathrm{g} \\
\text { cadmium in diet, } 2 \text {-year } \\
\text { study with two feeding } \\
\text { periods. }\end{array}$ & \\
\hline \multicolumn{6}{|c|}{ Lead } \\
\hline \multirow[t]{3}{*}{ Mute swan } & $\begin{array}{c}0.45 \\
{[1.35]}\end{array}$ & $\begin{array}{c}0.48 \\
{[1.44]}\end{array}$ & $\begin{array}{l}\text { Increase in blood lead, } \\
\text { decrease in ALAD. }^{\left({ }^{b}\right)}\end{array}$ & $\begin{array}{l}\text { Six-week feeding study } \\
\text { with reference contaminated } \\
\text { sediment at } 24 \% \text { of food }\end{array}$ & $\begin{array}{l}\text { Day et al. } \\
(2003)\end{array}$ \\
\hline & $\begin{array}{c}0.45 \\
{[1.35]}\end{array}$ & $\begin{array}{c}4.5 \\
{[13.5]}\end{array}$ & $\begin{array}{l}\text { Increase in brain, liver, and } \\
\text { blood lead, decrease in ALAD, } \\
\text { increase in protoporphyrin. }\end{array}$ & $\begin{array}{l}\text { Six-week feeding study } \\
\text { with lead contaminated } \\
\text { sediment at } 12 \% \text {. }\end{array}$ & \\
\hline & $\begin{array}{c}0.45 \\
{[1.35]}\end{array}$ & $\begin{array}{c}11.4 \\
{[34.2]}\end{array}$ & $\begin{array}{l}\text { Increase in brain, liver, and } \\
\text { blood lead, decrease in ALAD, } \\
\text { hematocrit, hemoglobin, } \\
\text { increase in protoporphyrin. } \\
\text { Indication of cellular effects in } \\
\text { kidney. }\end{array}$ & $\begin{array}{l}\text { Six-week feeding study } \\
\text { with lead contaminated } \\
\text { sediment at } 24 \% \text {. }\end{array}$ & \\
\hline \multicolumn{6}{|c|}{ Zinc } \\
\hline Mute swan & $\begin{array}{c}87 \\
{[261]}\end{array}$ & $\begin{array}{c}138 \\
{[416]}\end{array}$ & $\begin{array}{l}\text { Mean; slight increase in liver } \\
\text { zinc. }\end{array}$ & $\begin{array}{l}\text { Same study above; zinc also } \\
\text { highly elevated in sediment. }\end{array}$ & $\begin{array}{l}\text { Day et al. } \\
(2003)\end{array}$ \\
\hline \multicolumn{6}{|c|}{ Mercury } \\
\hline $\begin{array}{l}\text { Snowy } \\
\text { egret }\end{array}$ & $\begin{array}{c}0.48 \\
{[1.44]}\end{array}$ & $\begin{array}{c}1.17 \\
{[3.51]}\end{array}$ & $\begin{array}{l}\text { Mean; no effect on glutathione } \\
\text { of metallothionine; stable } \\
\text { isotope analysis of } \mathrm{N} \text { indicates } \\
\text { muscle catabolism. }\end{array}$ & $\begin{array}{l}\text { Sixty-day feeding study of } \\
\text { juvenile birds; mercury } \\
\text { present in contaminated and } \\
\text { noncomtaminated bass } \\
\text { flesh. }\end{array}$ & $\begin{array}{l}\text { Shaw-Allen et } \\
\text { al. }(2005)\end{array}$ \\
\hline Mallard & $\begin{array}{c}0.02 \\
{[0.06]}\end{array}$ & $\begin{array}{c}65 \\
{[195]}\end{array}$ & $\begin{array}{l}\text { Mean; altered }( \pm \text { ) activity of } \\
\text { four liver enzymes or liver } \\
\text { constituent; hematocrit, } \\
\text { hemoglobin and blood } \\
\text { phosphorus levels reduced. }\end{array}$ & $\begin{array}{l}9.2 \mathrm{mg} \mathrm{hg} / \mathrm{kg} \text { diet, } 10 \text {-week } \\
\text { feeding study with } 18- \\
\text { month-old ducks. }\end{array}$ & $\begin{array}{l}\text { Hoffman and } \\
\text { Heinz (1998) }\end{array}$ \\
\hline
\end{tabular}


Table B.2. (contd)

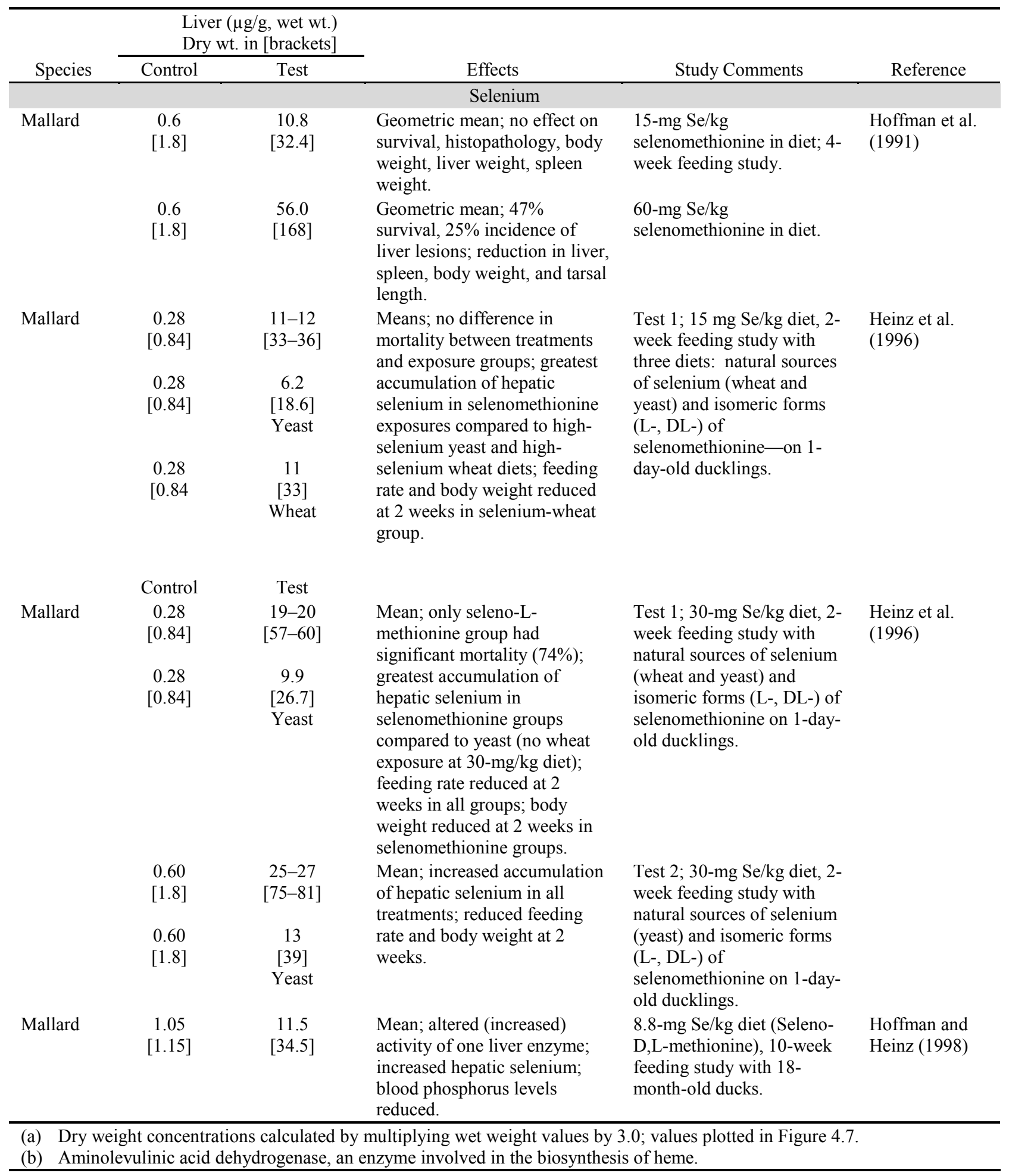


Validity of the comparisons to Canada geese depend on similarities in habitat and diet. All species live and feed in or near fresh water. The specific diets of the four species of ducks range from predominantly aquatic vegetation for the redhead and canvasback to aquatic invertebrates for the black duck and greater scaup. In comparison, Canada geese and lesser snow geese are upland grazers and generally feed on terrestrial plants (i.e., grasses and forbs). For some metals, comparisons were made to other published literature, but an extensive review of all technical literature was not attempted. Hanford Site Canada geese are primarily non-migratory, but the banding studies demonstrated that Hanford Site birds do disperse to other areas in the western United States and Canada. A portion of the Hanford Site goose population may consist of migratory birds that have moved to the Hanford Reach. The level of exposure to metals in migratory geese before residing at the Hanford Site is unknown. Sampling efforts, however, focused on birds that resided at the site for at least one nesting season by collecting them before fall migrants arrive on the site. These comparisons provide information describing contaminant levels found in Hanford Reach geese with respect to other waterfowl sampled in North America.

\section{B.1.1 Aluminum}

Aluminum concentrations in goose livers were highly variable with the majority of concentrations ranging between 1.3 and $8.9 \mu \mathrm{g} / \mathrm{g}$ dry wt, with two distinctly elevated concentrations of 13.8 and $54.2 \mu \mathrm{g} / \mathrm{g}$ dry wt (Appendix A). Aluminum is not routinely reported in the tissues of waterfowl. Data summarized by Rattner et al. (2006) had a reference for canvasback collected from San Francisco Bay; however, the values were listed as less than detection with no detection limit given. Hui et al. (1998) also reported aluminum concentrations in snow goose livers below the level of detection of $3.35 \mu \mathrm{g} / \mathrm{g}$ dry wt. Consequently, it is not possible to make direct comparisons of Hanford Reach goose livers to other waterfowl, based on the detection limit for snow geese. Hepatic aluminum concentrations in Hanford Site Canada geese likely met and exceeded those reported by Hui et al. (1998).

\section{B.1.2 Arsenic}

Arsenic concentrations in Canada goose livers ranged from below detection $(0.07$ to $0.2 \mu \mathrm{g} / \mathrm{g}$ dry wt depending on sample batch) to $0.75 \mu \mathrm{g} / \mathrm{g}$ dry wt. There were no arsenic results for waterfowl in the ERED, so comparisons were made using concentrations reported in other waterfowl where arsenic concentrations ranged from $0.25 \mu \mathrm{g} / \mathrm{g}$ dry wt for canvasback collected from San Francisco Bay to a sample mean of $2.78 \mu \mathrm{g} / \mathrm{g}$ dry wt for male greater scaup collected from Long Island Sound (Rattner et al. 2006). Other studies in the New England area reported mean concentrations for greater scaup ranging from 0.29 to $2.17 \mu \mathrm{g} / \mathrm{g}$ dry wt. Mean (range) concentrations of arsenic in redhead duck livers collected from Texas and Louisiana were $0.59(<0.30-2.70) \mu \mathrm{g} / \mathrm{g}$ dry wt (Rattner et al. 2006). Arsenic was not detected in the livers in lesser snow geese collected in California or Washington State (detection limit of $0.17 \mu \mathrm{g} / \mathrm{g}$ dry wt; Hui et al. 1998). Concentrations of arsenic in Hanford Reach Canada geese fell within the lower range of concentrations reported for other waterfowl.

\section{B.1.3 Cadmium}

Cadmium concentrations in Hanford Site Canada goose livers ranged from 0.22 to $15.6 \mu \mathrm{g} / \mathrm{g}$ dry wt. These concentrations are lower than liver concentrations known to be toxic in waterfowl (USACE/EPA 2005). When black ducks were fed a diet containing $4 \mu \mathrm{g} / \mathrm{g}$ cadmium with either $2 \%$ or $0.22 \%$ calcium in 
the feed (Silver and Nudds 1995, summarized in USACE/EPA 2005), the corresponding liver concentrations were 33 and $135 \mu \mathrm{g} / \mathrm{g}$ dry wt. At these levels, no effects were observed for growth and behavioral measurements including drinking, movement, resting behavior, and duration of inactivity. Additional information regarding the levels of cadmium and other contaminants in waterfowl and shorebirds can be found in Rattner et al. (2006). Generally, liver concentrations of cadmium fell below $7 \mu \mathrm{g} / \mathrm{g}$ dry wt in redhead and black duck samples. However, maximum levels of $21 \mu \mathrm{g} / \mathrm{g}$ dry wt were observed in greater scaup collected from San Francisco Bay. Mean ( \pm 1.0 SD) cadmium concentrations in lesser snow goose livers from geese that wintered in California were $1.9( \pm 1.0) \mu \mathrm{g} / \mathrm{g}$ dry wt, and $2.3( \pm 1.02) \mu \mathrm{g} / \mathrm{g}$ dry wt for snow geese that wintered in the Skagit Valley, Washington (Hui et al. 1998). Hepatic cadmium concentrations in Hanford Site Canada geese generally met and exceeded concentrations reported for waterfowl collected elsewhere in the country.

\section{B.1.4 Chromium}

Chromium concentrations in Hanford Site Canada goose livers ranged from 0.16 to $0.60 \mu \mathrm{g} / \mathrm{g}$ dry wt. There were no chromium results available for waterfowl in the ERED; however, data for chromium concentrations in black duck, canvasback, and greater scaup were summarized by Rattner et al. (2006). Mean liver concentrations of chromium in black duck were $6.15 \mu \mathrm{g} / \mathrm{g}$ dry wt. Liver concentrations in canvasback were reported as less than detection. Concentrations of chromium in greater scaup ranged from 0.65 to $3.07 \mu \mathrm{g} / \mathrm{g}$ dry wt, with mean values of 1.68 and 1.70 for males and females, respectively. Mean $( \pm 1.0 \mathrm{SD})$ concentrations of hepatic chromium in snow goose livers for geese that wintered in California were $1.3( \pm 0.42) \mu \mathrm{g} / \mathrm{g}$ dry wt and $1.03( \pm 0.51) \mu \mathrm{g} / \mathrm{g}$ dry wt for snow geese that wintered in the Skagit Valley, Washington (Hui et al. 1998). The distribution of chromium in Canada goose livers collected at the Hanford Site is similar to or lower than these reported levels.

\section{B.1.5 Copper}

Copper concentrations in Hanford Site Canada goose livers ranged from 13.2 to $125 \mu \mathrm{g} / \mathrm{g}$ dry wt. No copper results were available for waterfowl in the ERED; however, Rattner et al. (2006) cited reports for copper in canvasback, greater scaup, and redhead duck. Some studies of copper accumulation in waterfowl have shown that male birds maintain higher levels of copper in the liver than do females. Mean liver concentrations of copper in canvasback range from 99 to $187 \mu \mathrm{g} / \mathrm{g}$ dry wt. The range of copper concentrations in black duck liver was 1.5 to $235 \mu \mathrm{g} / \mathrm{g}$ dry wt, and the mean values for three separate studies in black duck ranged from 25.5 to $34.9 \mu \mathrm{g} / \mathrm{g}$ dry wt. Copper concentration in greater scaup livers ranged from 21 to $142 \mu \mathrm{g} / \mathrm{g}$ dry wt. For redhead ducks collected in Texas and Louisiana, liver concentrations ranged from 8 to $1030 \mu \mathrm{g} / \mathrm{g}$ dry wt, with a mean of $153 \mu \mathrm{g} / \mathrm{g}$ dry wt. The median (range) of copper in the livers of snow geese that wintered in California was $78(24.5-626) \mu \mathrm{g} / \mathrm{g}$ dry wt, and 46.7 (19.5-87.4) $\mu \mathrm{g} / \mathrm{g}$ dry wt for snow geese that wintered in the Skagit Valley, Washington (Hui et al. 1998). The distribution of copper in Canada goose livers collected at the Hanford Site is similar to or lower than these reported levels.

\section{B.1.6 Lead}

Lead concentrations in Canada goose livers ranged from 0.03 (detection limit) to $0.74 \mu \mathrm{g} / \mathrm{g}$ dry wt. Maximum levels of lead in goose liver were observed in birds collected from the 100 Areas $(0.74 \mu \mathrm{g} / \mathrm{g}$ dry wt). An analysis of variance indicated that lead levels were significantly higher for geese collected 
onsite (Table 4.3). Lead poisoning affects the formation of red blood cells (porphyria), and poisoning of waterfowl by the inadvertent ingestion of lead shot in dabbling waterfowl is a well-documented problem (Rattner et al. 2006). The mean concentration of lead in the livers of black ducks that had consumed lead shot was $36.8 \mu \mathrm{g} / \mathrm{g}$ dry wt in comparison to a mean concentration of $11.4 \mu \mathrm{g} / \mathrm{g}$ dry wt in specimens with no lead shot in their gizzards. Other measurements suggest a background level of 1.4 to $2.1 \mu \mathrm{g} / \mathrm{g}$ dry wt lead in the liver of black ducks. Similar concentrations have been documented for canvasback and greater scaup. Mean $( \pm 1.0 \mathrm{SD})$ concentrations of hepatic lead in snow geese that wintered in California were $50.2( \pm 185) \mu \mathrm{g} / \mathrm{g}$ dry wt; mean concentrations were $0.77( \pm 0.39) \mu \mathrm{g} / \mathrm{g}$ dry wt for snow geese that wintered in the Skagit Valley, Washington (Hui et al. 1998). The California samples had two occurrences that were very high: greater than 16 and greater than $600 \mu \mathrm{g} / \mathrm{g}$ dry wt. The distribution of lead in Canada goose livers collected at the Hanford Site is similar to or lower than these reported levels.

Calle et al. (1982) cited in Rattner et al. (2006) indicated that hepatic levels of lead at $6 \mu \mathrm{g} / \mathrm{g}$ wet wt $(18 \mu \mathrm{g} / \mathrm{g}$ dry wt) are associated with toxicity. Effects associated with lead poisoning in waterfowl as summarized in the ERED indicated measurable physiological and biochemical effects associated with concentrations of lead in liver ranging from 4.5 to $114 \mu \mathrm{g} / \mathrm{g}$ dry wt (USACE/EPA 2005). Effects included increased protoporphyrin, decreased enzyme activity, reduced hemoglobin, and suppressed growth. Most of these studies involved adding lead-contaminated sediment to the diet. Concentrations of hepatic lead in Canada geese collected at the Hanford Site are well below toxic benchmarks.

\section{B.1.7 Manganese}

Manganese concentrations in Canada goose livers from the Hanford Site ranged from 6.3 to $17.3 \mu \mathrm{g} / \mathrm{g}$ dry wt. The mean concentration of manganese in black duck collected from Raritan Bay was $5.54 \mu \mathrm{g} / \mathrm{g}$ dry wt (estimated from reported wet weight concentrations by a factor of 3). Black duck collected from Raritan Bay demonstrated a gender bias, with mean male liver concentrations of manganese $(6.57 \mu \mathrm{g} / \mathrm{g}$ dry wt converted from wet weight) exceeding concentrations in the livers of females $(3.80 \mu \mathrm{g} / \mathrm{g}$ dry wt converted from wet weight). Mean manganese concentrations in the livers of canvasback were 11.7 and $12.4 \mu \mathrm{g} / \mathrm{g}$ dry wt for two locations on the Gulf Coast by the Mississippi River delta. Mean liver concentrations in redhead were $7.27 \mu \mathrm{g} / \mathrm{g}$ dry wt, with a range of 3.88 to $11.5 \mu \mathrm{g} / \mathrm{g}$ dry wt. The mean $( \pm 1.0 \mathrm{SD})$ concentration of manganese in snow goose livers that wintered in California was $10.3( \pm 2.78) \mu \mathrm{g} / \mathrm{g}$ dry wt and $9.9( \pm 2.47) \mu \mathrm{g} / \mathrm{g}$ dry wt for snow geese that wintered in the Skagit Valley, Washington (Hui et al. 1998). Maximum manganese values in Hanford Site Canada goose livers generally exceed the values summarized by Rattner et al. (2006) for waterfowl.

\section{B.1.8 Mercury}

Mercury concentrations in Hanford Site Canada goose livers ranged from 0.019 to $0.157 \mu \mathrm{g} / \mathrm{g}$ dry wt. Maximum concentrations of mercury were observed in livers from Canada geese collected from the 100 Areas. Data listed in the ERED suggest that the liver concentrations in snowy egret of $8.5 \mu \mathrm{g} / \mathrm{g}$ dry wt were associated with no effect levels for the induction of metallothionine and glutathione (USACE/EPA 2005). Liver concentrations in the range of 2.4 to $9.2 \mu \mathrm{g} / \mathrm{g}$ dry wt were associated with mortality in brown pelicans, gulls, and cormorants. Rattner et al. (2006) provide a fairly comprehensive review of mercury data in waterfowl. Mean mercury levels in black duck livers ranged from 1.43 to $1.76 \mu \mathrm{g} / \mathrm{g}$ dry wt in birds collected from Raritan Bay, New Jersey. Mean liver concentrations in canvasback were 0.18 and $0.32 \mu \mathrm{g} / \mathrm{g}$ dry wt collected from two locations in Louisiana, while canvasback 
collected from San Francisco Bay had mean liver concentrations of $3.09 \mu \mathrm{g} / \mathrm{g}$ dry wt. Mean liver concentrations in canvasback collected from Wisconsin and Iowa ranged from 0.09 to $0.36 \mu \mathrm{g} / \mathrm{g}$ dry wt (converted from wet weight). Concentrations of mercury in greater scaup ranged from 1.8 to $66 \mu \mathrm{g} / \mathrm{g}$ dry wt depending on where the birds were collected, with the highest values associated with birds collected from San Francisco Bay. Mercury concentrations in livers of greater scaup collected in the New England area ranged from 0.87 to $3.8 \mu \mathrm{g} / \mathrm{g}$ dry wt. The concentration of mercury in redhead duck livers ranged from less than 0.02 to $1.53 \mu \mathrm{g} / \mathrm{g}$ dry wt for specimens collected from Texas and Louisiana. Mercury was not detected in the livers in snow geese collected in California or Washington State (detection limit of $0.34 \mu \mathrm{g} / \mathrm{g}$ dry wt; Hui et al. 1998). The distribution of mercury in Canada goose livers collected at the Hanford Site is similar to or lower than these reported levels.

The maximum concentration of mercury in Hanford Reach Canada geese kidney tissue was $0.119 \mu \mathrm{g} / \mathrm{g}$ dry wt (Table A.1). Mean mercury concentrations in greater scaup kidney tissue collected from Long Island Sound, New England, were 0.149 in males and 0.167 in females (Rattner et al. 2006). Other studies reported a range of mercury concentrations of 0.32 to $2.83 \mu \mathrm{g} / \mathrm{g}$ dry wt in New England greater scaup (Rattner et al. 2006). There were no other kidney values for redhead, black duck, or canvasback in Rattner et al. (2006). For the kidney samples analyzed from 2001, concentrations of mercury from Canada geese fell below levels reported for other waterfowl.

\section{B.1.9 Selenium}

Selenium concentrations in Canada goose livers ranged from 1.25 to $7.45 \mu \mathrm{g} / \mathrm{g}$ dry wt. Selenium concentrations in Canada goose liver met some of the lower biochemical biomarker levels established for mallard ducks (USACE/EPA 2005). These biomarkers are indicative of exposure but are not necessarily associated with specific adverse effects. Selenium may reduce levels of glutathione and glutathione disulfide in duck liver at levels of 3.9 to $6 \mu \mathrm{g} / \mathrm{g}$ dry wt. Decreased growth was reported in mallard ducks where liver concentrations of selenium was $9 \mu \mathrm{g} / \mathrm{g}$ dry wt; immune function was depressed at $15 \mu \mathrm{g} / \mathrm{g}$ dry wt, and dead or deformed embryos were reported when liver concentrations reach $17.2 \mu \mathrm{g} / \mathrm{g}$ dry wt (USACE/EPA 2005). Although selenium has toxic properties, it is also an essential micronutrient. Selenium is a component of glutathione peroxidases, which are primarily responsible for reducing peroxide-free radicals that include lipid-peroxide formation in cell membranes. Consequently, the biochemical relationships of selenium in mallard duck liver and potential adverse effects are not clearly defined and are separated by a small increase in hepatic liver concentrations of selenium. Concentrations of selenium have been summarized for canvasback, redhead, and greater scaup (Rattner et al. 2006), where observed concentrations in liver ranged from 6.7 to $140 \mu \mathrm{g} / \mathrm{g}$ dry wt liver. The highest liver concentrations of selenium occurred in greater scaup collected from the San Francisco Bay area. A concentration of about $21 \mu \mathrm{g} / \mathrm{g}$ dry wt was the upper bound of background concentrations and the lower bound for waterfowl collected from a contaminated site. Mean ( $\pm 1.0 \mathrm{SD})$ concentrations of selenium in the livers of snow geese that wintered in California were $4.4( \pm 1.00) \mu \mathrm{g} / \mathrm{g}$ dry wt and $4.2( \pm 0.84) \mu \mathrm{g} / \mathrm{g}$ dry wt for snow geese that wintered in the Skagit Valley, Washington (Hui et al. 1998). The distribution of selenium in Canada goose livers collected at the Hanford Site is similar to or lower than these reported levels. 


\section{B.1.10 Thallium}

Thallium concentrations in goose liver ranged from less than detection $(0.004 \mu \mathrm{g} / \mathrm{g}$ dry wt in 2005 Priest Rapids area geese) to $0.099 \mu \mathrm{g} / \mathrm{g}$ dry wt. None of the four main waterfowl species summarized by Rattner et al. (2006) had listings for thallium in any waterfowl organ or tissue, nor did Hui et al. (1998) report thallium concentrations for snow geese. Consequently, there is no comparative basis for assessing thallium concentrations for other waterfowl.

\section{B.1.11 Zinc}

Zinc concentrations in Canada goose livers ranged from 107 to $290 \mu \mathrm{g} / \mathrm{g}$ dry wt. Other studies of zinc accumulation in waterfowl have shown that male birds maintain higher levels of zinc in the liver than do females (Rattner et al. 2006). Concentrations of zinc in black duck ranged from 29 to $495 \mu \mathrm{g} / \mathrm{g}$ dry wt in birds collected from Chesapeake Bay. Black duck collected from Raritan Bay demonstrated a gender bias, with mean male liver concentrations of zinc $(150 \mu \mathrm{g} / \mathrm{g}$ dry $\mathrm{wt})$ exceeding concentrations in the livers of females $(54 \mu \mathrm{g} / \mathrm{g}$ dry wt). Mean zinc concentrations in the livers of canvasback were 128 and $137 \mu \mathrm{g} / \mathrm{g}$ dry wt for two locations on the Gulf Coast by the Mississippi River delta. Mean liver concentrations of zinc in canvasback collected from San Francisco Bay were $160 \mu \mathrm{g} / \mathrm{g}$ dry wt. Mean liver concentrations of zinc in greater scaup ranged from 151 to $174 \mu \mathrm{g} / \mathrm{g}$ dry wt and showed small variations based on season and location around San Francisco Bay. A separate study cited by Rattner et al. (2006) along the California coast demonstrated a range of zinc concentrations in greater scaup liver from 133 to $193 \mu \mathrm{g} / \mathrm{g}$ dry wt. The mean concentrations ranged from 134 to $181 \mu \mathrm{g} / \mathrm{g}$ dry wt and varied based on age and sex of the birds. Mean zinc concentrations in greater scaup collected from the New England area ranged from 57.9 to $180 \mu \mathrm{g} / \mathrm{g}$ dry wt and also demonstrated a sexual bias for higher levels in male birds. Mean zinc concentrations in redhead were $122 \mu \mathrm{g} / \mathrm{g}$ dry wt and ranged from 68 to $337 \mu \mathrm{g} / \mathrm{g}$ dry wt. The median (range) concentrations of hepatic zinc in lesser snow geese that wintered in California were $89.2(55.6-414) \mu \mathrm{g} / \mathrm{g}$ dry wt and $133(77.5-408) \mu \mathrm{g} / \mathrm{g}$ dry wt for snow geese that wintered in the Skagit Valley, Washington (Hui et al. 1998).

\section{B.2 Group II Metals}

Group II metals were those metals whose concentrations in liver were frequently less than detection or were only intermittently reported. The concentrations of antimony, beryllium, and nickel were below detection in more than $60 \%$ of the goose liver samples collected in 2003 and 2005 (Appendix A). For silver, thorium, and uranium, the laboratory achieved detection limit (LADL) in 2005 was significantly lower, and 2005 samples had measurable concentrations while those collected in 2003 principally did not. Barium was reported in only one of two sample batches in 2003. Because of the variable nature of measured values, comparisons between years and sampling locations are difficult for most cases. Descriptive statistics are summarized in Table A.3, Appendix A.

A survey of redhead, greater scaup, black duck, and canvasback files in Rattner et al. (2006) indicated no data for antimony, beryllium, barium, thorium, or uranium. Hui et al. (1998) had analyzed liver samples for beryllium, barium, and nickel, but the results were less than detection $(0.07,0.67$, and $0.40 \mu \mathrm{g} / \mathrm{g}$ dry wt, respectively). Rattner et al. (2006) summarized some information on nickel and silver. 


\section{B.2.1 Nickel}

Most of the liver samples from Canada geese collected on the Hanford Site were below detection $(0.45 \mu \mathrm{g} / \mathrm{g}$ dry wt) for nickel; however, the maximum concentration was observed at $0.26 \mu \mathrm{g} / \mathrm{g}$ dry wt. Nickel results were summarized for black duck, greater scaup, and canvasback by Rattner et al. (2006). Black ducks collected on the Raritan Bay in New Jersey had a mean hepatic concentration of $4.6 \mu \mathrm{g} / \mathrm{g}$ dry wt in liver. In a subsequent study, no statistical difference was reported for males $(5.8 \mu \mathrm{g} / \mathrm{g}$ dry wt) compared to females $(3.1 \mu \mathrm{g} / \mathrm{g}$ dry wt). Mean liver concentration in greater scaup collected from Raritan Bay in the early $1980 \mathrm{~s}$ was $3.6 \mu \mathrm{g} / \mathrm{g}$ dry wt. When segregated by sex, the mean liver concentrations in males were lower than females, 2.7 to $5.8 \mu \mathrm{g} / \mathrm{g}$ dry wt, respectively. Nickel was detected in less than half of 18 greater scaup collected from San Francisco Bay in 1982 and was below detection in all canvasback collected in 1988. Mean liver concentrations of nickel in greater scaup collected from Long Island Sound were $15.4 \mu \mathrm{g} / \mathrm{g}$ dry wt. Subsequent sampling indicated no difference in mean hepatic concentrations of nickel in females compared to males ( 1.35 and $1.34 \mu \mathrm{g} / \mathrm{g}$ dry wt, respectively). Canvasback livers collected in 1976 from Iowa were grouped by sex and age; converted mean dry weight concentrations (approximately $0.06 \mu \mathrm{g} / \mathrm{g})$ for adult males $(N=5)$, adult females $(N=5)$, and immature males $(N=5)$; concentrations were less than $0.06 \mu \mathrm{g} / \mathrm{g}$ for immature females $(N=5)$. Overall, concentrations of nickel in Canada goose livers collected on the Hanford Site were similar to or lower than concentrations reported for other waterfowl sampled in the United States.

\section{B.2.2 Silver}

Concentrations of silver in Canada goose livers were generally below detection in 2003, but improvements to the analysis resulted in all 2005 sample results exceeding the detection limit of $0.003 \mu \mathrm{g} / \mathrm{g}$ dry wt. The maximum concentration was $0.085 \mu \mathrm{g} / \mathrm{g}$ dry wt. Rattner et al. (2006) reported silver in

greater scaup livers collected in San Francisco Bay at a geometric mean concentration of $1.10 \mu \mathrm{g} / \mathrm{g}$ dry wt (range of 0.39 to 3.1 ).

\section{B.3 References}

Bagley GE and LN Locke. 1967. "The occurrence of lead in tissues of wild birds." Bulletin of Environmental Contamination and Toxicology 2:197-305.

Baker FD, CF Tumasonis, WB Stone, and B Bush. 1976. "Levels of PCB and trace metals in waterfowl in New York State.” New York Fish and Game Journal 23:82-91.

Barclay JS and JM Zingo. 1993. "Winter scaup populations in Connecticut coastal waters." CT Warbler 13:136-150.

Barclay JS, CR Perkins, ME Tomassone, and KE Eccleston. 1995. Declining Populations of Ducks As Influenced by Habitat Quality in Long Island Sound - Final Report. Department of Natural Resource Management and Engineering, University of Connecticut, Storrs.

Burger J and M Gochfeld. 1985. "Comparisons of nine heavy metals in salt gland and liver of greater scaup (Aythya marila), black duck (Anas rubripes) and mallard (A. platyrhynchos)." Comparative Biochemistry and Physiology C -- Toxicology \& Pharmacology 81C:287-292. 
Calle PP, DF Kowalczyk, FJ Dein, and FE Hartman. 1982. "Effect of hunters' switch from lead to steel shot on potential for oral lead poisoning in ducks." Journal of the American Veterinary Medicine Association 18:1299-1301.

Cohen JB, JS Barclay, AR Major, and JP Fisher. 2000. "Wintering Greater Scaup as biomonitors of metal contamination in Federal Wildlife Refuges in the Long Island region." Archives of Environmental Contamination and Toxicology 38:83-92.

Custer TW and WL Hohman. 1994. "Trace-Elements in Canvasbacks (Aythya-Valisineria) Wintering in Louisiana, USA, 1987-1988.” Environmental Pollution 84(3)253-259.

Dale IM, MS Baxter, JA Bogan, and WRP Bourne. 1973. "Mercury in seabirds." Marine Pollution Bulletin 4:77-79.

DiGiulio RT and PF Scanlon. 1984. "Heavy metals in tissues of waterfowl from the Chesapeake Bay." Environmental Pollution (Series A) 35:29-48.

Gochfeld M and J Burger. 1982. "Biological concentration of cadmium in estuarine birds of the New York Bight." Colonial Waterbirds 5:116-123. (Editor's note: In 1999, the journal was renamed Waterbirds; for details, see http://www.waterbirds.org/journal.htm [February 2010]).

Gochfeld M and J Burger. 1987. "Heavy metal concentrations in the liver of three duck species: Influence of sex and species." Environmental Pollution 45:1-15.

Hoffman DJ, HM Ohlendorf, CM Marn, and GW Pendleton. 1998. "Association of mercury and selenium with altered glutathione metabolism and oxidative stress in diving ducks from the San Francisco Bay region, USA.” Environmental Toxicology and Chemistry 17(2):167-172.

Hothem RL, DG Lonzarich, KE Takekawa, and HM Ohlendorf. 1998. "Contaminants in wintering canvasbacks and scaups from San Francisco Bay, California.” Environmental Monitoring and Assessment 50:67-84.

Hui CA, JY Takekawa, VV Baranyuk, and KV Litvin. 1998. "Trace Metal Concentrations in Two Subpopulations of Lesser Snow Geese from Wrangel Island, Russia." Archives of Environmental Contamination and Toxicology 34:197-203.

Michot TC, TW Custer, AJ Nault, and CA Mitchell. 1994. "Environmental contaminants in redheads wintering in coastal Louisiana and Texas." Archives of Environmental Contamination and Toxicology $26: 425-434$.

Miles AD and HM Ohlendorf. 1993. "Environmental contaminants in canvasbacks wintering on San Francisco Bay, California.” California Fish and Game 79:28-38.

Ohlendorf HM, RW Lowe, PR Kelly, and TE Harvey. 1986. "Selenium and Heavy Metals in San Francisco Bay Diving Ducks.” Journal of Wildlife Management 50(1):64-70. 
Rattner BA et al. 2006. "Contaminant Exposure and Effects - Terrestrial Vertebrates (CEE-TV)

Database. Version 8.0. Updated March 2008." U.S. Geological Survey, Patuxent Wildlife Research

Center, Laurel, Maryland. Available at http://www.pwrc.usgs.gov/contaminants-online/ (February 2010).

Scanlon PF, VD Stotts, RG Oderwald, TJ Dietrick, and RJ Kendall. 1980. "Lead concentrations in livers of Maryland waterfowl with and without ingested lead shot present in gizzards." Bulletin of Environmental Contamination and Toxicology 25:855-860.

Silver TM and TD Nudds. 1995. "Influence of low-level cadmium and reduced calcium intake on tissue Cd concentrations and behavior of American Black ducks.” Environmental Pollution 90:153-161.

USACE/EPA (U.S. Army Corps of Engineers/U.S. Environmental Protection Agency). 2005. "The Environmental Residue-Effects Database (ERED).” Available at http://el.erdc.usace.army.mil/ered/ (February 2010).

Vermeer K and DB Peakall. 1979. "Trace metals in seaducks of the Fraser River Delta intertidal area, British Columbia." Marine Pollution Bulletin 10:189-193.

White DH, RC Stendell, and BM Mulhern. 1979. "Relations of Wintering Canvasbacks to Environmental Pollutants - Chesapeake Bay, Maryland.” Wilson Bulletin 91(2):279-287. 


\section{Distribution}

No. of

Copies

\section{OFFSITE}

B.L. Tiller

P.O. Box 265

Richland, WA 99352

S. Harris

Confederated Tribes of the Umatilla

Indian Reservation

P.O. Box 638

Pendleton, OR 97801

B. Harper

Confederated Tribes of the Umatilla

Indian Reservation

750 Swift, Suite 14

Richland, WA 99352

R. Brunoe, GW Natural Resource

Confederated Tribes of Warm Springs

Reservation

P.O. Box 1299

Warm Springs, OR 97761

A. Nomee

Department of Natural Resources

Coeur d'Alene Tribe

P.O. Box 408

Plummer, ID 83851-9703

D. Landeen

Hanford Natural Resources Trustee

Council

Nez Perce Tribe

P.O. Box 365

Lapwai, ID 83540
No. of

$\underline{\text { Copies }}$

C. Andrade

National Oceanic and Atmospheric

Administration

DARC 7600

Sandpoint Way NE

Seattle, WA 98115

G. Bohnee

Nez Perce Tribe

P.O. Box 365

Lapwai, ID 83540

Director - Hanford Project Office

Office of Environmental Cleanup

$12006^{\text {th }}$ Avenue

Seattle, WA 98101

P. Shaffer

Oregon Department of Energy

625 Marion Street NE

Salem, OR 97301-3737

2 U.S. Environmental Protection Agency

309 Bradley, Suite 115, MS B1-46

Richland, WA 99352

L. Buelow

L. Gadbois

H. Newsome

Hanford Reach National Monument

U.S. Fish and Wildlife Service

64 Maple Street

Burbank, WA 99323

L. Albright

U.S. Fish and Wildlife Service

64 Maple Street

Burbank, WA 99323 
No. of

Copies

2 Wanapum

P.O. Box 878

Ephrata, WA 98823

L. Buck

R. Buck, Jr.

J. Price

Washington Department of Ecology

3100 Port of Benton Boulevard

Richland, WA 99354

M. Livingston

Washington Department of Fish and

Wildlife

2620 N. Commercial Avenue

Pasco, WA 99301

J. Skriletz

Washington Department of Fish and

Wildlife

600 Capitol Way

1111 Washington Street NE

Olympia, WA 98501-1091

L. Goldstein

Washington State Department of

Ecology

P.O. Box 47600

Olympia, WA 98504

E. Kramer

Division of Radiation Protection

Washington State Department of Health

P.O. Box 47827

Olympia, WA 98504-7827

D. McBaugh

Washington State Department of Health

P.O. Box 47827

Olympia, WA 98504-7827
No. of

\section{Copies}

M. Priddy

Washington State Department of Health 309 Bradley, Suite 201

Richland, WA 99352

R. Jim, Manager

Yakama Nation

2808 Main Street

Union Gap, WA 98903

J. McConnaughey

Yakama Nation

P.O. Box 6066

Kennewick, WA 99336-0066

P. Rigdon

Yakima Nation

P.O. Box 151

Toppenish, WA 98948

\section{ONSITE}

2 DOE Office of River Protection
L. A. Huffman
H6-60
W. Russell
H6-60

DOE Pacific Northwest Site Office

J. Erickson K9-42

11 DOE Richland Operations Office

J. R. Franco

A3-04

J. A. Hansen

A5-11

R. G. Hastings

A5-19

A. R. Hawkins

A5-14

J. P. Sands

A3-04

K. M. Thompson

A6-38

D. C. Ward

A5-15

S. R. Weil

A5-15

J. Zeisloft

A3-04

DOE Public Reading Room (2) H2-53 
No. of

Copies

2 Mission Support Alliance, LLC
A. R. Johnson
R3-12
C. J. Perkins
H7-28

2 Washington Closure Hanford, LLC

D. Jacques

H4-22

L.C. Hulstrom

H4-22
No. of

Copies

16 Pacific Northwest National Laboratory

E. J. Antonio

K3-54

J. M. Becker

K6-85

L. E. Bisping

K6-75

R. L. Dirkes

K6-75

J. L. Downs

K6-85

C. A. Duberstein

K6-85

B. G. Fritz

K6-75

D. R. Geist

K6-85

K. D. Hand

K6-85

B. E. Opitz

K6-75

G. W. Patton

K6-75

T. M. Poston

K6-75

M. R. Sackschewsky

K6-85

M. A. Simmons

K6-85

J. A. Stegen

K3-66

Historical File - T. M. Poston

K6-75 


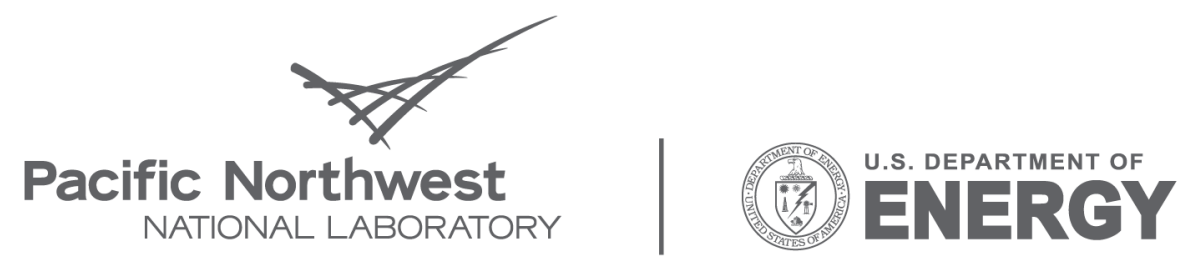

Proudly Operated by Battelle Since 1965

902 Battelle Boulevard

P.O. Box 999

Richland, WA 99352

1-888-375-PNNL (7665)

www.pnl.gov 